UNIVERSIDADE DE SÃO PAULO

FACULDADE DE MEDICINA DE RIBEIRÃO PRETO

PROGRAMA DE PÓS-GRADUAÇÃO EM BIOLOGIA CELULAR E MOLECULAR

O papel de gangliosídeos específicos como moduladores da liberação de mediadores de mastócitos

Edismauro Garcia Freitas Filho

Ribeirão Preto 
EDISMAURO GARCIA FREITAS FILHO

\title{
O papel de gangliosídeos específicos como moduladores da liberação de mediadores de mastócitos
}

\author{
Dissertação de mestrado apresentada à \\ Faculdade de Medicina de Ribeirão Preto da \\ Universidade de São Paulo para obtenção do \\ título de Mestre em Ciências: Biologia \\ Celular e Molecular
}

Edismauro Garcia Freitas Filho Orientadora: Profa. Dra. Maria Célia Jamur

\author{
Ribeirão Preto
}


Autorizo a reprodução e divulgação total ou parcial deste trabalho, por qualquer meio convencional ou eletrônico, para fins de estudo e pesquisa, desde que citada a fonte.

Catalogação da Publicação

Serviço de Documentação

Faculdade de Medicina de Ribeirão Preto da Universidade de São Paulo

Freitas-Filho, Edismauro Garcia

O papel de gangliosídeos específicos como moduladores da liberação de mediadores de mastócitos

Ribeirão Preto, 2015

116 p.; il.; $30 \mathrm{~cm}$.

Dissertação de mestrado, apresentada à Faculdade de Medicina de Ribeirão Preto da Universidade de São Paulo. Departamento de Biologia Celular e Molecular e Bioagentes Patogênicos. Área de concentração: Biologia Celular e Molecular.

Orientadora: Jamur, Maria Célia

1. Mastócitos; 2. Gangliosídeos; 3. Lipid rafts; 4. Via de sinalização. 
Aluno: Freitas-Filho, Edismauro Garcia

Título: O papel de gangliosídeos específicos como moduladores da liberação de mediadores de mastócitos

Dissertação apresentada à Faculdade de Medicina de Ribeirão Preto da Universidade de São Paulo para a obtenção do título de Mestre em Ciências. Área de concentração: Biologia Celular e Molecular. Orientadora: Profa. Dra. Maria Célia Jamur

Aprovado em:

\section{Banca Examinadora}

Prof. Dr.:

Instituição:

Assinatura:

Prof. Dr.:

Instituição:

Assinatura:

Prof. Dr.:

Instituição:

Assinatura: 
"I was here. I lived, I loved. I was here. I did, I have done everything that I wanted and it was more than I thought it would be. I will leave my mark so everyone will know, I was here."

Giselle Knowles Carter 
DEDICATÓRIA 
À MINHA FAMÍLIA...

\section{MEU PAI, EdisMAUro GARCIA FreITAS}

Minha MÃE, Maisa Carvalho Garcia

MEU IRMÃO, EdisMair CARVAlho Garcia

Minha irMÃ, Mariana Carvalho Garcia.

AGRADEÇO A VOCÊS TODO O CARINHO E ATENÇÃO A MIM

DEDICADA DURANTE ESSES ANOS. SEM VOCÊS ESTE PERCURSO NÃO TERIA SIDO POSSÍVEL. AGRADEÇO-VOS DO FUNDO DO CORAÇÃO POR TODO O APOIO, INCENTIVO E ACIMA DE TUDO POR NUNCA TEREM DEIXADO DE ACREDITAR EM MIM. AO NOSSO AMOR INCONDICIONAL, OBRIGADO.

\section{AMO TDOS VOCÊS.}


AGRADECIMENTOS 


\section{À DEUS, \\ nosso pai celestial, \\ o grande arquiteto do universo... \\ pelo dom da vida e da sabedoria.}


À minha orientadora Profa. Dra. Maria Célia Jamur, agradeço pela orientação precisa em todos os momentos, pelos ensinamentos valiosos, por respeitar e me ajudar a superar minhas inseguranças, pela confiança em mim depositada, pelo ótimo convívio e carinho em todos os momentos. Minha eterna admiração e gratidão pela oportunidade de crescimento científico.

À Profa. Dra., Constance Oliver co-orientadora deste trabalho, meus sinceros agradecimentos pelos ensinamentos, tempo dedicado, paciência, confiança, apoio, carinho e exemplo de dedicação à pesquisa.

“SE HOJE EU VEJO MAIS LONGE, É PORQUE ME APOIEI EM OMBROS DE GIGANTES..." 


\section{Agradeço ainda:}

Aos professores doutores do departamento de Biologia Celular e Molecular e Bioagentes Patogênicos Enilza Maria Espreafico, Maria Cristina Roque Barreira, Maria Luiza Paçó Larson, pelos ensinamentos transmitidos e disponibilidade de seus laboratórios.

Ao Dr. Prof. Eduardo M. Rego, à Dra. Profa. Célia Maria de A. Soares, ao Dr. Prof. Clayton Borges e à Dra. Profa. Cristiane M. de Gaitani pela disponibilidade de seus laboratórios.

Ao Prof. Dr. Pietro Ciancaglini, do departamento de Química (FFCL-USP), por todos os momentos em que se disponibilizou a me ajudar. Minha eterna gratidão e reconhecimento. Tenha certeza de que suas palavras contribuíram para a concretização deste trabalho e para o meu aprimoramento pessoal.

Aos docentes que aceitaram fazer parte da Banca Examinadora da defesa deste trabalho, muito obrigado pela disponibilidade e atenção dispensada.

Agradeço também a todos os professores que, direta ou indiretamente, contribuíram para minha formação acadêmica durante o mestrado.

Aos meus amigos do laboratório de Biologia Celular e Molecular dos Mastócitos: Ana Carolina Santana, Antônio Borges, Clarissa Valim, Devandir Antônio de Souza Junior, Elaine Zayas, Valéria Barbosa, Vanina Toso e Vivian Mazucato, William Maximiano, meus sinceros agradecimentos pelo ótimo convívio, onde cada um 
demonstrou características únicas de amizade, companheirismo e, acima de tudo, respeito. Guardarei sempre comigo um pouco de vocês.

Ao funcionário Anderson Roberto de Souza agradeço pelos serviços técnicos do laboratório.

À técnica Dra. Roberta Rosales obrigado pela amizade e pelo valioso apoio técnico nos ensaios de microscopia de fluorescência.

\section{Á técnica Dra. Priscila Scheucher e à técnica Mariana Barbieri pela} disponibilidade quase que imediata de seus serviços, com certeza eles foram de grande valia para a realização deste trabalho.

À primeira “orientadora da minha vida”, Profa. Dra. Cecília Nunes Moreira. Você me fez ver que em qualquer começo a dúvida sobre o caminho é inevitável, mas sempre existe alguém pra lhe receber e dizer que as portas estão abertas caso você queira crescer. Agradeço não somente pelas primeiras oportunidades de pesquisa, mas também pelo incentivo e exemplos de sua doutrina idônea. Enfim, por todos os ensinamentos que transcendem à Academia, muito obrigado minha sempre amiga Cissa.

Um obrigado mais que especial à velhas amigas de estrada, Carolinne (Carol), Jéssica (Fiota) e Gabriela (Gabi). Agradeço por todo o apoio, amizade, paciência e companheirismo sempre demonstrados. Todas me ajudaram a enfrentar, direta ou indiretamente, os desafios e derrotas, mas sempre acreditando e comemorando no final de cada vitória. 
Ao grande amigo Pedro (Asltolfinho), obrigado pela sua amizade e companheirismo incontestáveis. Agradeço ainda os inúmeros conselhos, aprendizados e incentivos sempre presentes. Estar com você nesta caminhada é muito especial para mim.

Aos amigos Maira (Mai) e Marcos, cada qual com sua peculiaridade de ser é responsável pelo meu sucesso hoje. Obrigado pela simplicidade e pureza de suas amizades.

Às princesas Laurine (Laurys) Mariana (Marys) e Lílian (Lílys). Minhas amigas, estar com vocês no Laboratório de Biologia Molecular (LBM) não me trouxe somente resultados científicos, e o "proteoma" que me desculpe, mas o maior ganho desta experiência foi poder conhecer vocês e criar este vínculo de amizade que jamais será esquecido. Muito obrigado por todo o carinho e todas as discussões de assuntos aleatórios bem como daqueles fundamentais para nosso crescimento pessoal. Adoro vocês.

Às minhas amigas Daniela (Dani), Mayara (May) e Taís. Muito obrigado por não ser preciso falar sempre de biologia celular. O grupo "Onde vamos comer?" me sacia. Por estar nesta com vocês, eu me sinto empanturrado de carrinho e farto de alegria. Brincadeiras à parte, agradeço por vocês estarem ao meu lado durante esta etapa em Ribeirão Preto, sem vocês, não teria a mesma graça e felicidade. Que perdure o afeto e a amizade, obrigado sempre.

À secretária da pós-graduação Gabriela Bunhotto Zamoner agradeço a permanente disponibilidade e serviços prestados. 
Às secretárias do Departamento de Biologia Celular e Molecular e Bioagentes Patogênicos, Lúcia Helena Picinato Raphael e Camila Fabris, muito obrigado pelos ótimos serviços prestados.

À Universidade Federal de Goiás (UFG) - Regional Jataí pela minha formação profissional.

À CAPES, FAEPA e FAPESP, pelo apoio financeiro à realização deste trabalho. 


\section{ÍNDICE}

RESUMO i

ABSTRACT V v

INTRODUÇÃO 1

Características dos mastócitos 2

A transdução do sinal via FceRI

$\begin{array}{ll}\text { Sinais inibitórios nas etapas iniciais da ativação } & 10\end{array}$

$\begin{array}{ll}\text { Lipid rafts } & 12\end{array}$

$\begin{array}{ll}\text { Gangliosídeos derivados do } \mathrm{GD}_{1 \mathrm{~b}} & 17\end{array}$

OBJETIVOS

MATERIAL E MÉTODOS

1. Cultura de células 25

2. Anticorpos 26

3. Ensaio de ativação do fator de transcrição NFAT 28

4. Ensaio de ativação do fator de transcrição NFאB 29

5. Sorting das linhagens repórteres VB9, NFkB2, IH10 e IC2 30

6. Análise da liberação de mediadores neo-sintetizados 31

7. Análise da liberação de mediadores neoformados 31

8. Caracterização da composição proteica dos lipid rafts 32

8.1 Purificação de lipid rafts por fracionamento subcelular em gradiente de 32 sacarose

8.2 Slot Blot 33

8.3.Extração, quantificação e Western Blot das proteínas presentes nas frações 34 de lipid rafts

8.4 Redução, alquilação e digestão das proteínas para análise NanoUPLC-MS ${ }^{\mathrm{E}} \quad 36$

8.5. Análise NanoUPLC-MS ${ }^{\mathrm{E}} 37$

8.6 Processamento de dados e identificação das proteínas 38

9. Imunofluorescência 39

10. Análise estatística 40

RESULTADOS

1. O intercruzamento dos gangliosídeos derivados do $\mathrm{GD}_{1 \mathrm{~b}}$ pelo mAb AA4 42 promove a ativação dos fatores de transcrição NFAT e NFkB 
2. O intercruzamento dos gangliosídeos derivados do $\mathrm{GD}_{1 \mathrm{~b}}$ pelo mAb AA4 resulta na liberação de mediadores neo-sintetizados

3. O intercruzamento dos gangliosídeos derivados do GD $1 \mathrm{~b}$ pelo mAb AA4 não resulta na liberação de mediadores neoformados

4. A agregação dos gangliosídeos derivados do GD 1 b resulta na desorganização dos lipid rafts de mastócitos RBL-2H3

5. Proteoma comparativo dos lipid rafts de mastócitos RBL-2H3 com ou sem a 56 agregação dos gangliosídeos derivados do $\mathrm{GD}_{1 \mathrm{~b}}$

6. Análise das proteínas up reguladas nos lipid rafts quando os gangliosídeos derivados do $\mathrm{GD}_{1 \mathrm{~b}}$ estão agregados

6.1 Vimentina

7. Análise das proteínas down reguladas nos lipid rafts quando os gangliosídeos derivados do $\mathrm{GD}_{1 \mathrm{~b}}$ estão agregados 
RESUMO 


\section{RESUMO}

Os mastócitos são células multifuncionais do sistema imunológico que participam em diversos processos biológicos. As funções dos mastócitos estão diretamente relacionados com a sua ativação e, subsequente, liberação de mediadores químicos. Os eventos iniciais da ativação dos mastócitos e da transdução de sinais ocorrem em microdomínios lipídicos (lipid rafts) da membrana plasmática. Os gangliosídeos derivados do $\mathrm{GD}_{1 \mathrm{~b}}$ são constituintes dos lipid rafts de mastócitos de roedores. O intercruzamento destes gangliosídeos pelo mAb AA4, resulta na formação de agregados (caps) na superfície celular e promove uma ativação parcial dos mastócitos, sem que ocorra a desgranulação. A ativação é semelhante a observada quando os FcદRIs são intercruzados por antígenos multivalentes ligados a IgEs, mas neste caso ocorre a desgranulação. O presente estudo tem como objetivo caracterizar o papel dos gangliosídeos derivados do GD $1 \mathrm{~b}$ na liberação de mediadores de mastócitos da linhagem RBL-2H3. O intercruzamento dos gangliosídeos derivados do $\mathrm{GD}_{1 \mathrm{~b}}$ resulta na ativação dos fatores de transcrição NFAT e NFkB e esta ativação é mediada pela proteína quinase Syk. A ativação destes fatores de transcrição resulta na liberação de mediadores neo-sintetizados, tais como: TNF- $\alpha$, interleucina (IL)-4. Por outro lado, o intercruzamento dos gangliosídeos derivados de $\mathrm{GD}_{1 \mathrm{~b}}$ não induz a liberação dos mediadores neoformados como o leucotrieno B4 (LTB4) e o leucotrieno C4 (LTC4). A agregação dos gangliosídeos derivados do $\mathrm{GD}_{1 \mathrm{~b}}$ resulta na desorganização dos lipid rafts e na redistribuição de seus componentes, como demostrado pela análise proteômica. Estes dados mostraram proteínas capazes de desencadear uma ativação parcial dos mastócitos e proteínas reguladoras negativas da desgranulação estão up reguladas, enquanto que proteínas críticas para a transdução do sinal estão down reguladas. Os resultados obtidos neste trabalho demonstram que os gangliosídeos 
derivados do $\mathrm{GD}_{1 \mathrm{~b}}$ desempenham papel crucial na integridade dos lipid rafts modulando a ativação e liberação de mediadores de mastócitos. 
ABSTRACT 


\begin{abstract}
Mast cells are immunoregulatory cells that participate in diverse biological events. The action of mast cells is directly related to their activation and subsequent mediator release. Early signal transduction events occur in lipid rafts in the plasma membrane. GD b- $^{-}$ derived gangliosides are known constituents of lipid rafts in rodent mast cells. The crosslinking of these gangliosides by mAb AA4 results in a partial activation of mast cells similar to that observed when FceRIs are cross-linked, but does not result in the mast cell degranulation. With time, the gangliosides bound to mAb AA4 cap on the cell surface. The present study aims to characterize the role of the rodent mast cell specific gangliosides derived from $\mathrm{GD}_{1 \mathrm{~b}}$ in mediator release from RBL-2H3 mast cells. Crosslinking the $\mathrm{GD}_{1 \mathrm{~b}}$-derived gangliosides activated the transcription factors NFAT and NFkB and this activation was mediated by Syk. The activation of theses transcription factors by cross-linked $\mathrm{GD}_{1 \mathrm{~b}}$-derived gangliosides results in the release of the neosynthesized mediators TNF- $\alpha$ and interleukin (IL)-4. However, cross-linking GD bb- $^{-}$ derived gangliosides did not stimulate release of the newly formed mediators leukotriene B4 (LTB4) and leukotriene C4 (LTC4). Capping of $\mathrm{GD}_{1 b}$-derived gangliosides disorganized lipid rafts and resulted in a redistribution of lipid raft components. Proteomic analysis showed that proteins that trigger mast cell activation and negative regulatory proteins of degranulation are up regulated, whereas proteins critical for signal transduction are down regulated in mast cells where the gangliosides are capped. The results of this work demonstrate that the mast cell-specific $\mathrm{GD}_{1 b}$-derived gangliosides are crucial in maintaining the functional integrity of the lipid rafts and modulate cell activation and subsequent mediator release from mast cells.
\end{abstract}


INTRODUÇÃO 


\section{INTRODUÇÃO}

\section{CARACTERÍSTICAS DOS MASTÓCITOS}

Os mastócitos são células multifuncionais do sistema imunológico com participação importante nas imunidades inata e adquirida. Assim como as células sanguíneas, os mastócitos são derivados de células hematopoiéticas progenitoras. Diferentes da maioria das células sanguíneas, os mastócitos deixam a medula óssea ainda como células progenitoras imaturas que migram para tecidos periféricos, aonde irão terminar o processo de maturação sob influências de fatores presentes no microambiente tecidual (Galli et al, 2011; Jamur \& Oliver, 2011). Utilizando o isolamento imunomagnético sequencial com dois anticorpos específicos de mastócitos (mAb AA4 e mAb BGD6), as células progenitoras (mast cell committed precursor - MCcp) provenientes da medula óssea de camundongos adultos foram isoladas e caracterizadas. Os MCcp são $\mathrm{CD} 13^{+}, \mathrm{CD} 34^{+}, \mathrm{c}-\mathrm{Kit}^{+}, \mathrm{Fc \varepsilon RI}$, e contém mRNA para as subunidades $\alpha \mathrm{e}$ $\beta$ do FceRI bem como para as proteases especificas de mastócitos mMCP-5, mMCP-7 e carboxipeptidase A (CPA) (da Silva et al, 2014; Jamur et al, 2005).

Os mastócitos atuam em diferentes processos biológicos, tais como: defesa do hospedeiro contra patógenos invasores, reações inflamatórias e alérgicas (imediata e tardia), reparo tecidual, manutenção da homeostase, angiogênese e eliminação de parasitas (Anand et al, 2012; de Souza et al, 2012; Galli et al, 2005; Kalesnikoff \& Galli, 2008; Koketsu et al, 2013; Metcalfe \& Boyce, 2006; Settipane \& Schwindt, 2013).

Os mastócitos apresentam o seu citoplasma repleto de grânulos que se coram metacromaticamente devido à interação dos corantes básicos (catiônicos) com os resíduos ácidos (aniônicos) das cadeias de glicosaminoglicanas (GAGs) sulfatadas (heparina e 
sulfato de condroitina) da proteoglicana serglicina, presente abundantemente nos grânulos (Abrink et al, 2004; Jorpes, 1935). Ultraestruturalmente, estas células podem ser reconhecidas pelos grânulos elétron-densos presentes no citoplasma. Os mastócitos estão localizados no tecido conjuntivo e a sua morfologia varia de acordo com as características do microambiente; são alongados ou ovoides quando próximos a vasos sanguíneos, arredondados quando presentes no lavado peritoneal e estrelados ou fusiformes, quando localizados entre as fibras da derme. Geralmente, os mastócitos são mais abundantes nos tecidos conjuntivos próximos a vasos sanguíneos, nervos e regiões susceptíveis à entrada de patógenos no organismo, como pele e mucosas. No homem e nos roedores, apresentam uma heterogeneidade baseada na sua localização e nas características morfológicas, bioquímicas, histoquímicas e funcionais (Irani et al, 1986; Metcalfe et al, 1997b). Desta forma os mastócitos são classificados em mastócitos de mucosa (MMC - Mucosal Mast Cell) e mastócitos de tecido conjuntivo (CTMC - Conective Tissue Mast Cell) (Yong, 1997, Gaytan et al., 1990).

A participação dos mastócitos nos diferentes processos ocorre através de sua ativação e subsequente liberação de diversos mediadores. A ativação destas células ocorre por meio de estímulos diversos sob diferentes receptores presentes na superfície destas células. A magnitude e a natureza das respostas dos mastócitos aos diferentes estímulos podem ser influenciadas por fatores intrínsecos e do microambiente, que afetam o padrão de expressão ou funcionalidade de receptores de superfície ou moléculas sinalizadoras que contribuem para essas respostas (Galli et al, 2005; Gilfillan \& Beaven, 2011; Metcalfe et al, 2009).

O mecanismo de ativação mais conhecido é regulado através do receptor de alta afinidade para a imunoglobulina $\mathrm{E}(\mathrm{IgE}), \mathrm{o}$ FceRI. O FceRI é um receptor que pertence à classe de receptores multicadeia de reconhecimento imune que incluem receptor de 


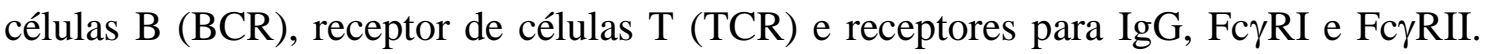
Esses receptores possuem sequências conhecidas como motivos de ativação baseados em tirosinas de imunoreceptores, assim denominados ITAMs (immunoreceptor tyrosinebased activation motif) que possuem seus resíduos tirosina separados por 6-8 resíduos de aminoácidos. O FceRI é um complexo proteico tetramérico com 3 subunidades $(\alpha \beta \gamma 2)$ e não possui atividade enzimática intrínseca (Cambier, 1995; Metzger et al, 1986; Siraganian et al, 2010).

Quando as IgE, que estão ligadas aos FceRIs, são intercruzadas por antígenos específicos ocorre a agregação dos receptores e a ativação da via de transdução de sinal. A ativação dos mastócitos resulta na produção e liberação de inúmeros produtos farmacologicamente ativos, tais como: mediadores pré-formados: substâncias como a histamina, heparina, $\beta$-hexosaminidase, proteoglicanas, proteases neutras, triptases, carboxipeptidase A, quimases e algumas citocinas que participam da imunidade, da hematopoiese, do remodelamento dos tecidos e de diversos processos biológicos. Dentre esses fatores estão também as interleucinas (IL)-8 e IL-16 e alguns fatores como o TNF$\alpha$ (Tumor Necrosis Factor), b-FGF (Fibroblast Growth Factor), VEGF (Vascular Endothelial Growth Factor), TGF- $\beta$ (Transforming Growth Factor Beta) dentre outros, além do próprio SCF (Stem Cell Factor) que é liberado sem perder seu efeito biológico sobre os mastócitos. Estas substâncias são produzidas e armazenadas nos grânulos citoplasmáticos dos mastócitos; mediadores neoformados: como a $\mathrm{PGD}_{2}$ (prostaglandina $\mathrm{D}_{2}$ ), leucotrienos como o $\mathrm{LTC}_{4}$ e LTB 4, PAF (Platelet Activating Factor) e tromboxanas. Estas substâncias originam-se pela ativação da fosfolipase A2 e são derivadas do metabolismo do ácido araquidônico sendo formados logo após a ativação dos mastócitos; mediadores neo-sintetizados: a síntese dos mesmos ocorre em 8-24 horas após a desgranulação, dentre eles destacam-se as interleucinas IL-3, IL-4, IL-5 e 
IL-6 e o fator estimulador de colônias granulócito/macrófago (GM-CSF), TGF- $\beta$ e o TNF- $\alpha$ (Kushnir-Sukhov et al, 2007; Pejler et al, 2010; Rivera et al, 2008). Fatores neoformados e neo-sintetizados, porém, podem ser liberados sem que ocorra a desgranulação dos mastócitos (Grodzki et al, 2009).

\section{A TRANSDUÇÃO DO SINAL VIA FcERI}

Como descrito anteriormente, os mastócitos quando ativados desencadeiam diferentes respostas biológicas tais como: secreção de componentes pré-formados dos grânulos, síntese e secreção de mediadores lipídicos neoformados e síntese e secreção de mediadores neo-sintetizados, as citocinas (Nadler et al, 2001; Siraganian et al, 2010). Essas respostas formam a base de um dos mais potentes sistemas para a imunidade e hipersensibilidade imediata, que inclui a anafilaxia. A anafilaxia é uma variante máxima em uma alergia do tipo imediata e aguda com risco de vida (Ring et al, 2010). A eficiência desta resposta imune depende da ligação da IgE ao FcદRI. A cadeia $\alpha$ do receptor liga-se a porção Fc da IgE na razão de 1:1 enquanto as cadeias $\beta$ - e $\gamma$-possuem ITAMs em seus domínios citoplasmáticos (Metzer, 2002). O receptor FceRI não possui atividade enzimática intrínseca, portanto, o passo inicial na ativação dos mastócitos através do FceRI é a fosforilação dos seus domínios ITAMs pelas proteínas tirosina quinase da família Src (PTKs). Ainda é desconhecido quantas e quais PTKs são essenciais para sinalização dos mastócitos, entretanto, a transfosforilação dos resíduos de tirosina presentes nos ITAMs do FcદRI acontece pela ação da PTK Lyn, ou outra PTK que seja capaz de se associa ao receptor. A fosforilação eficiente do FcદRI requer regiões especializadas da membrana plasmática, os lipid rafts, onde Lyn e FceRI podem ser concentrados nestes microdomínios após o intercruzamento do receptor. Os ITAMs 
recém-fosforilados constituem um novo sítio de ligação recrutando a PTK Syk (spleen tyrosine kinase) que se liga, principalmente, à subunidade $\gamma$ do receptor, sendo Sky uma tirosina quinase crucial para ativação dos mastócitos. Esta ligação resulta na alteração conformacional da Syk, seguida por sua autofosforilação e ativação (Benhamou et al, 1993; de Castro et al, 2010; Holowka \& Baird, 2001; Siraganian, 2003; Underhill \& Goodridge, 2007; Zhang et al, 2000).

A ativação de Syk resulta na fosforilação de múltiplos substratos como, por exemplo, as proteínas de membrana LAT1 (linker for activatin of $T$ cells) e LAT2 (NTAL), que ativam a via PI3K (fosfatidilinositol-3-quinase) e a PTK Btk. A LAT fosforilada funciona como proteína de ancoragem para diversos complexos multimoleculares da sinalização que incluem adaptadores presentes no citoplasma, como Gads, Grb2, SLP-76 e Shc; os permutadores guanosina trifosfato, incluindo Sos e Vav; e as enzimas fosfolipases C $\gamma 1$ (PLC $\gamma 1$ ) e PLC $\gamma 2$ (Iwaki et al, 2005; Kalesnikoff \& Galli, 2008).

A agregação do receptor também resulta na ativação da via mediada pela PTK Fyn, que fosforila Gab2. A proteína Gab2 fosforilada se liga à subunidade p82 do PI3K. O Complexo PI3K-Gab2 é translocado para a membrana plasmática onde a reação de conversão do $\mathrm{PIP}_{2}$ (fosfatidilinositil-4, 5-bifosfato) para fosfatidilinositol-3, 4, 5trifosfato $\left(\mathrm{PIP}_{3}\right)$ é catalisada. $\mathrm{O} \mathrm{PIP}_{3}$ recruta então para membrana plasmática proteínas tais como, Btk, PLC $\gamma 1$ e PLC $\gamma 2$, que são fundamentais para a subsequente propagação do sinal (Siraganian, 2003). Outras PTKs têm sido descritas na via de ativação dos mastócitos, como a Fgr e Hck. A Fgr se associa ao FceRI e fosforila Syk. Já Hck é reguladora positivo da atividade da PTK Lyn. Ambas as PTKs agem então como reguladores positivos na ativação e desgranulação dos mastócitos induzida por antígeno (Hong et al, 2007; Lee et al, 2011). 
As fosfolipases $\mathrm{C} \gamma$ ativadas por essa via são translocadas para a membrana plasmática onde, juntas com Btk, hidrolisam $\mathrm{PIP}_{2}$ produzindo os mensageiros secundários DAG (diacilglicerol) e $\mathrm{IP}_{3}$ (inositol-1, 4, 5-trifosfato), que vão, respectivamente, resultar na ativação de $\mathrm{PKC}$ (proteína quinase $\mathrm{C}$ ) e a rápida liberação de cálcio intracelular $\left[\mathrm{Ca}^{2+}\right]_{\mathrm{i}}$. A ligação de $\mathrm{IP}_{3}$ aos receptores de $\mathrm{IP}_{3}\left(\mathrm{IP}_{3} \mathrm{R}\right)$ na membrana do retículo endoplasmático (RE) leva a liberação de $\mathrm{Ca}^{2+}$ dos reservatórios do $\mathrm{RE}$, resultando na diminuição na concentração de cálcio dentro desta organela. Esse aumento transitório do $\left[\mathrm{Ca}^{2+}\right]_{\text {i }}$ não é suficiente para a maioria das respostas celulares. Sendo assim, a diminuição do $\mathrm{Ca}^{2+}$ estocado dentro do RE resulta no grande influxo de $\mathrm{Ca}^{2+}$ pela membrana plasmática. Duas moléculas, Stim1 e Orai1, foram identificadas como responsáveis por este processo. Orai1 é uma subunidade do canal CRAC (calcium release-activated calcium) enquanto Stim1 é um sensor de cálcio do RE. A depleção de cálcio no RE induz a aposição das membranas RE-membrana plasmática onde Stim1 interage diretamente com a proteína Orai1 abrindo os canais CRAC e permitindo o aumento intracelular de cálcio (Baba et al, 2008; Hitomi et al, 2004; Vig \& Kinet, 2009). Já o diacilglicerol ativa PKC, em especial PKC $\alpha$ e $\beta$. A PKC é multifuncional e fosforila radicais serina e treonina de diversas proteínas alvo, porém, só é enzimaticamente ativa na presença de $\mathrm{Ca}^{2+}$ e fosfatidilserina. Após o aumento do $\left[\mathrm{Ca}^{2+}\right]_{\mathrm{i}}$ juntamente com a participação das proteínas do complexo SNARE e as proteínas do citoesqueleto há a liberação dos mediares pré-formados, que estão armazenados nos grânulos citoplasmáticos dos mastócitos (Figura 1) (Dráber et al, 2012; Riviera \& Gilfillan, 2006; Siraganian et al, 2010). 


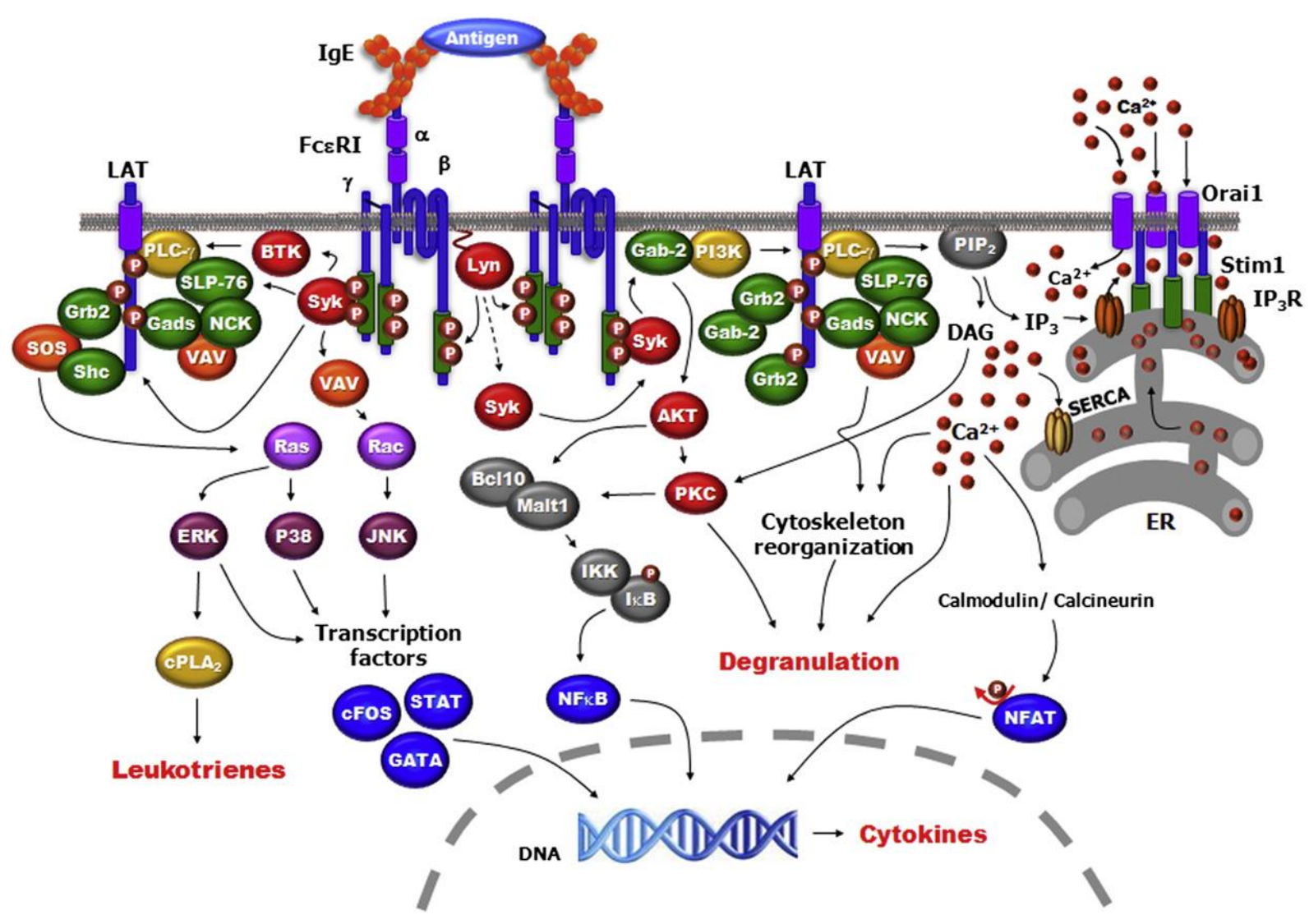

Figura 1. Modelo ilustrando as principais moléculas e os eventos na ativação dos mastócitos. Quando as IgEs ligadas ao FceRI são intercruzadas por antígenos multivalentes ocorre a fosforilação das ITAMs presentes nas subunidades $\beta$ e $\gamma$ do receptor do FceRI pela Lyn. A PTK Syk é recrutada e, posteriormente, ativada quando se liga ao ITAM fosforilado da subunidade $\gamma$; a Syk ativada se autofosforila e ativa a fosforilação de Btk, PI3K, LAT, SLP-76 e PLC $\gamma$. Complexos multimoleculares são formados pela LAT com Gads, SLP-76, PLC $\gamma$ e Vav. A PLC $\gamma$ ativada hidroliza PI(4,5)P 2 para formar $\mathrm{DAG}$ e $\mathrm{IP}_{3}$. $\mathrm{O} \mathrm{IP}_{3}$ ativa o receptor $\mathrm{IP}_{3} \mathrm{R}$ no $\mathrm{RE}$ e ocorre liberação de cálcio. $\mathrm{O}$ sensor de cálcio Stim1 interage com a proteína de membrana Orai1 abrindo os canais CRAC resultando no aumento intracelular de cálcio. DAG ativa PKC que interage com a calmodulina para ativar calcineurina levando a translocação de NFAT para o núcleo. A

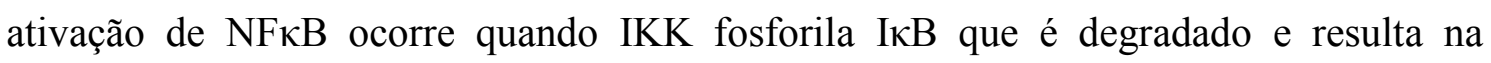
translocação de NFkB para o núcleo. A ativação de GTPases leva a ativação das MAP kinases. Essas vias resultam na desgranulação, liberação de mediadores lipídicos e síntese de citocinas. (Siraganian et al., 2010). 
A fosforilação da proteína adaptadora LAT resulta na formação de uma "plataforma molecular" que serve de ligação e agregação para inúmeras proteínas ativadas, como as proteínas adaptadoras Shc, Grb2 e Sos. Essas proteínas ativadoras estimulam pequenas GTPases como a Ras, que ativam a proteína ERK, que por sua vez irão levar a ativação da fosfolipase A2. PLA2 libera ácido araquidônico que será metabolizado pelas vias ciclooxigenase ou lipooxigenase formando os mediadores neoformados. Esses compostos, sintetizados no citoplasma, se difundem através da membrana plasmática por serem derivados de lipídeos (Figura 1) (Boyce, 2007; Riviera \& Gilfillan, 2006).

A proteína Syk ativada recruta e fosforila também a proteína Vav. A Vav fosforilada estimula pequenas GTPases como a Rac, Ras e Rho resultando no estímulo das vias ERK, JNK e p-38 MAP-quinase. As MAP quinases são importantes mediadores da sinalização entre o citoplasma e o núcleo regulando diversos fatores de transcrição. Sendo de grande importância para a síntese dos mediadores neo-sintetizados os fatores de transcrição NFAT (Nuclear factor of activated T cells) e NFאB (Nuclear fator-kappa B) (Benhamou \& Siraganian, 1992; Metcalfe et al, 1997a).

O aumento de cálcio intracelular ativa a calcineurina, uma serina treonina fosfatase dependente de $\mathrm{Ca}^{2+} /$ calmodulina. A calcineurina desfosforila NFAT resultando em mudanças conformacionais que expõem as sequências de localização nuclear, que se ligam a importinas, permitindo a translocação do NFAT para o núcleo e iniciando a transcrição de diversos genes responsáveis pela expressão de citocinas inflamatórias e regulatórias, como por exemplo IL-2, IL-4, IL-3 e TNF- $\alpha$ (Figura 1) (Klein et al, 2006; Monticelli et al, 2004; Okamura et al, 2000).

Outro fator de transcrição essencial que regula a expressão de citocinas nos

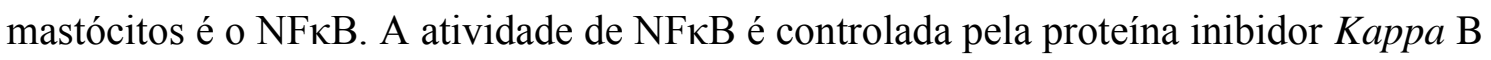
(IאB) que se liga a este fator no citoplasma mantendo-o em sua conformação inativa. A 


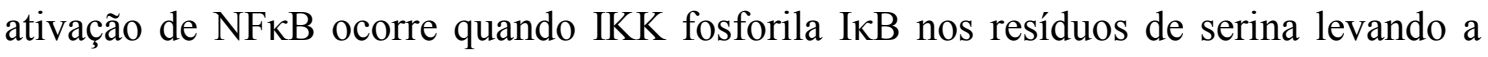
degradação de IкB via proteassomo após a poliubiquitinação, o que resulta na

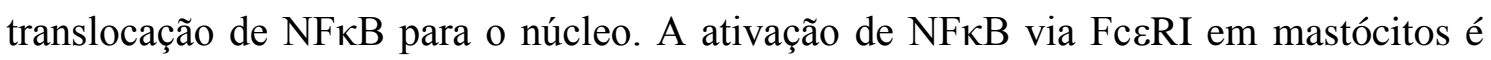
dependente da ativação e recrutamento de PKC $\beta$ e a formação do complexo formado por Bcl-10 (B cell lymphoma 10) e Malt1 (mucosal-associated lymphoid tissue 1) nos lipid rafts. O NFkB se liga a regiões regulatórias de genes envolvidos na produção de citocinas relacionadas à inflamação, como IL-4, IL-6 e TNF- $\alpha$, resultando na expressão e liberação destas citocinas. A obtenção dos níveis máximos de secreção destas classe de mediadores requer várias horas (Figura 1) (Hoesel \& Schmid, 2013; Gilfillan \& Tkaczyk, 2006, Klemm et al., 2006).

\section{SINAIS INIBITÓRIOS NAS ETAPAS INICIAIS DA ATIVAÇÃO}

Os sinais inibitórios são iniciados simultaneamente aos sinais de ativação. O estímulo via FcદRI resulta no aumento da fosforilação de tirosinas da proteína ligante de Csk (Cpb), também conhecida como fosfoproteína associada aos domínios ricos em glicoesfingolipídeos (PAG). A Cbp fosforilada recruta a proteína tirosina quinase Csk para os domínios ricos em glicoesfingolipídeos, onde irá fosforilar a tirosina regulatória carboxiterminal das PTKs, como por exemplo a Lyn, suprimindo assim, a sua atividade. A ativação dos mastócitos, além de resultar na fosforilação das tirosinas dos ITAMs, promove também a fosforilação dos motivos ITIMs (Immunoreceptor Tyrosine-based Inhibition Motif) que recrutam moléculas de sinalização negativa como a fosfatase SHIP1 (SH2-containing inositol-5'-phosphatase) (Siraganian, 2003). Interessantemente, a PTK Lyn fosforila e ativa SHIP1 em mastócitos. Lyn também fosforila a PKC $\delta$, e o complexo Lyn-SHIP1-PKC $\delta$ foi verificado. A SHIP1 também pode se ligar ao ITAM fosforilado da 
subunidade $\beta$ do FceRI e as duas tirosinas fosforiladas de LAT. Estes dados indicam a existência de um complexo de sinalização inibitório (Hernandez-Hansen et al, 2004; Huber \& Gibbs, 2015; Kimura et al, 1997; Roget et al, 2008).

A SHIP1 age degradando o PIP $_{3}$ gerado pela PI3K. A desgranulação e a produção de citocinas são mais elevadas em mastócitos derivados da medula óssea (BMMCs) SHIP1-negativos do que nos BMMCs tipo-selvagem (Kalesnikoff et al, 2002; Siraganian, 2003). A porção C terminal de SHIP1 pode recrutar a proteína adaptadora DOK (downstream of kinase), que recruta a proteína Ras GAP, regulando negativamente a atividade de Ras p21, uma proteína G que é crucial para o início da via MAP quinase (Figura 2) (Huber \& Gibbs, 2015; Tamir et al, 2000).

O papel das fosfatases SHPs (Tyrosine-protein phosphatase non-receptor) é bem estabelecido como moléculas de sinalização negativas na regulação da ativação de células da linhagem hematopoiética. A proteína tirosina fosfatase SHP-1 (Tyrosine-protein phosphatase non-receptor type 6) é recrutada pelos receptores que contêm ITIMs. A ligação de SHP-1 aos ITIMs fosforilados aumenta a sua atividade levando a desfosforilação das tirosinas presentes nas moléculas de sinalização, como por exemplo, Syk, SLP-76 e Vav. A SHP-1, provavelmente, desfoforila ITIMs permitindo um feedback da sinalização inibitória (Bounab et al, 2013).

O receptor FC $\gamma$ RII possui um domínio intracitoplasmático contendo ITIM que pode influenciar na ativação via FceRI. A agregação de FC $\gamma$ RII não leva a fosforilação dos ITIMs, portanto, é necessária a co-agregação de receptores que contém ITAMs, como o FceRI. Essa co-agregação ativa as PTKs que fosforilam os ITAMs dos receptores ativatórios. Estes por sua vez, irão fosforilar os ITIMs dos receptores inibitórios no complexo de sinalização. A fosforilação dos ITIMs permite o recrutamento de proteínas regulatórias negativas da ativação, como a SHIP1, o que resulta na inibição da 
desgranulação e da liberação de mediadores inflamatórios pelos mastócitos (Gilfillan \& Beaven, 2011; MacGlashan Jr et al, 2012; Malbec et al, 1998).

Outras proteínas como a PTEN e PECAM-1 (Platelet Endothelial Cell Adhesion Molecule-1) e outros receptores como MAFA (Mast Cell Function-associated Antigen) CD200R, CD300a, CD300f e alergina-1 também atuam como reguladores negativos da desgranulação em mastócitos (Abramson et al, 2003; Hitomi et al, 2010; Wong et al, 2002).

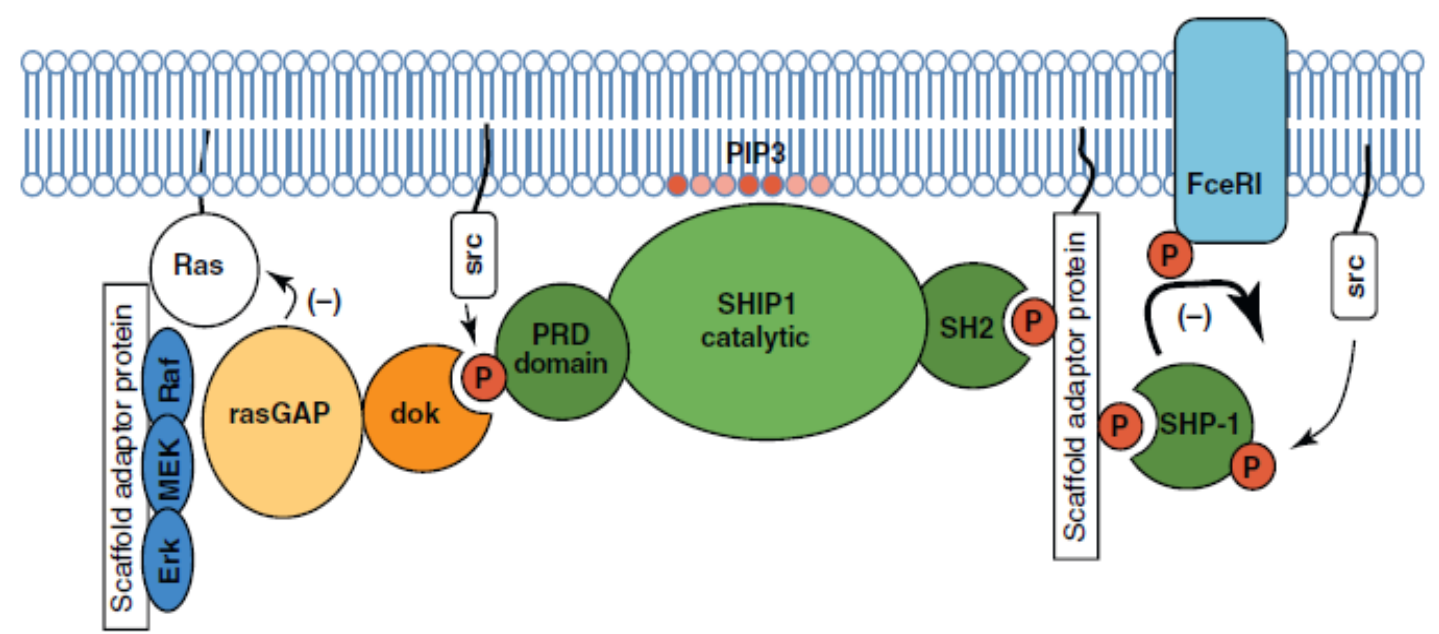

Figura 2. Eventos iniciais da inibição e da ativação dos mastócitos. A SHIP1 regula a presença de $\mathrm{PIP}_{3}$ que recruta várias proteínas de sinalização positiva para a membrana plasmática. A porção C terminal de SHIP1, próxima ao domínio PRD (tirosina fosforilada por PTKs) pode recrutar a proteína adaptadora DOK. A DOK recruta Ras GAP que regula negativamente a atividade de Ras p21, que é crucial para o início da via MAP quinase. SHP-1 é recrutada quando a via de sinalização é ativada regulando tirosinas presentes nas moléculas de sinalização positiva, como Syk, SLP-76 e Vav. (MacGlashan Jr, 2012).

\section{LIPID RAFTS}

O conceito sobre as membranas biológicas tem mudado em relação ao modelo do mosaico fluido (Singer \& Nicolson, 1972) Este modelo se caracteriza pela distribuição homogênea de lipídios e proteínas ao longo de um espaço bidimensional. $\mathrm{Na}$ nova 
concepção, as membranas são compartimentalizadas em vários microdomínios como resultado de uma distribuição assimétrica de lipídios e/ou proteínas específicos (Anderson \& Jacobson, 2002).

Os lipid rafts são microdomínios lipídicos associados à proteínas de forma ordenada na membrana plasmática e em outras membranas intracelulares. Estes componentes se associam e dissociam em curtíssimo espaço de tempo, podendo variar em estabilidade, tamanho, forma e composição molecular (Simons \& Gerl, 2010). Lindner \& Naim (2009) ressaltam que: “Hoje, não há dúvidas de que estruturas ordenadas que diferem na composição de seus lipídios e/ou proteínas existam nas membranas biológicas". A real natureza dos lipid rafts é extremamente complexa e o entendimento de como ocorre a formação, modulação e sustentação destes microdomínios permanece ainda um desafio.

Os microdomínios lipídicos são ricos em esfingolipídeos (como a esfingomielina), gangliosídeos e colesterol. Na sua composição lipídica, predominam longas cadeias de hidrocarbonetos saturadas que potencializam a interdigitação entre os folhetos e favorecem a interação com o colesterol. Algumas proteínas são restritas a estas regiões ou estão concentradas nestes microdomínios. As proteínas ancoradas por glicosilfosfatidilinositol (GPI) estão concentradas no lado externo da membrana plasmática, enquanto proteínas com modificações lipídicas (palmitoilação e miristoilação) e proteínas que se ligam ao colesterol estão concentradas no lado citoplasmático da membrana plasmática (Figura 3). Os lipid rafts são fundamentais para a regulação e função de várias proteínas associadas à membrana (Brown \& London, 1998; Brown \& Rose, 1992; Dráber \& Dráberová, 2002; Harder et al, 1998; Holowka et al, 2000; Simons \& Ikonen, 1997; Silveira e Souza et al., 2011). 


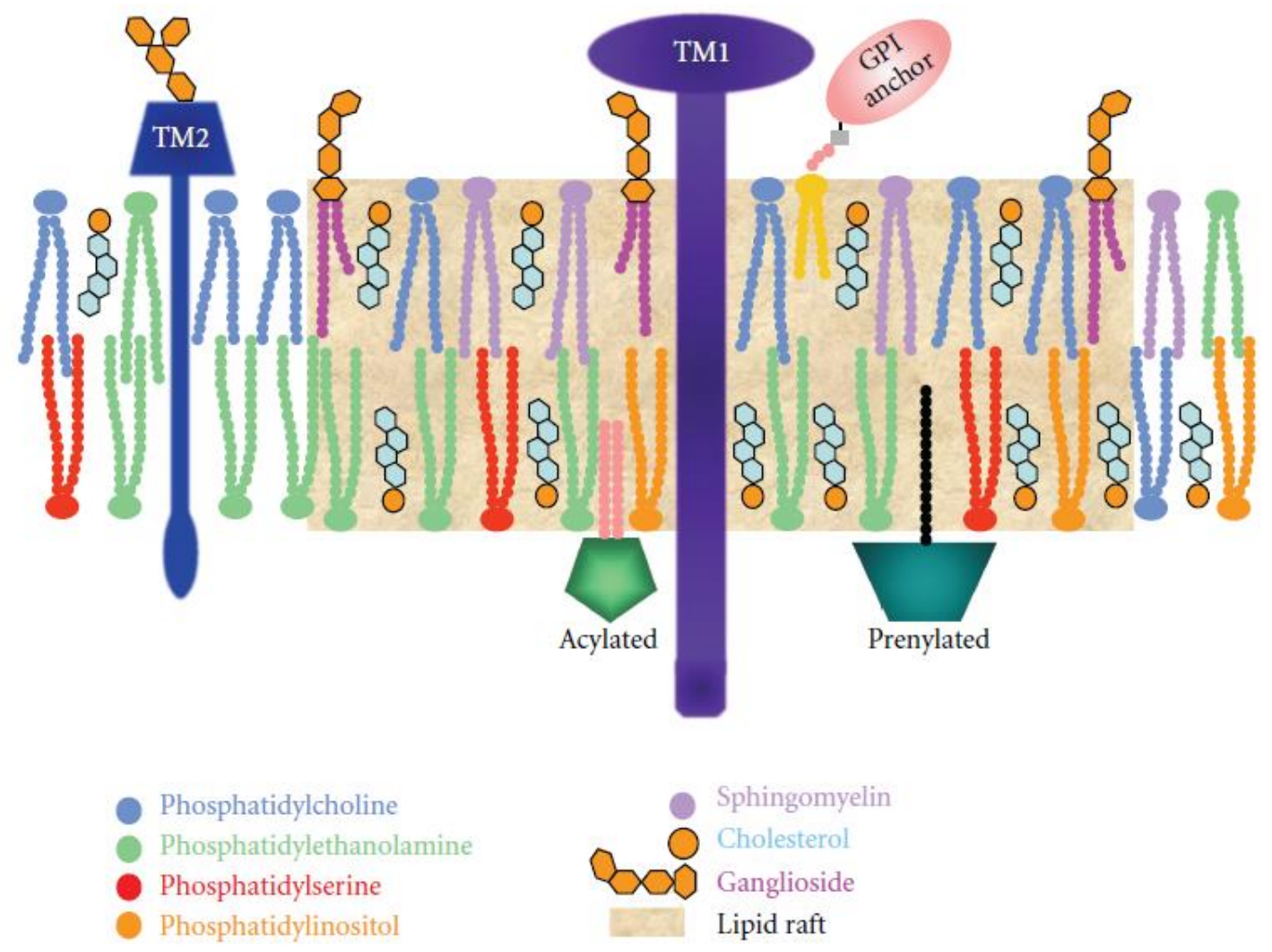

Figura 3. Diagrama dos lipid rafts. Os lipid rafts são ricos em colesterol, esfingolipídios e gangliosídeos. Proteínas ancoradas por GPI, esfingomielina, fosfatidilcolina e gangliosídeos estão presentes no lado externo da membrana plasmática. Proteínas preniladas e acetiladas, fosfatidilserina e fosfatidiletanolamina estão presentes no lado interno da membrana plasmática. O colesterol está presente em ambos os lados. TM1 e TM2 (proteínas transmembrana 1 e 2). (Silveira e Souza et al., 2011).

Os lipid rafts já eram alvo de pesquisas e de discussões antes mesmo do desenvolvimento de técnicas experimentais que permitissem desvendar a sua existência (Masserine \& Freire, 1986). Com o desenvolvimento de técnicas microscópicas mais avançadas, diferentes domínios fluídos foram identificados na membrana plasmática por segregação preferencial, quando marcados com sondas e corantes (Abulrob et al, 2008). Os lipid rafts são resistentes à extração com detergentes não iônicos em baixa concentração como o Triton X-100, podendo ser isolados dos domínios não-rafts da membrana plasmática e que flutuam em gradientes de sacarose, sendo denominados DRMs (detergente-resistante membranes) (Holowka et al, 2000). Os 
DRMs podem representar as propriedades dos lipid rafts que ocorrem nas células vivas (Sonnino \& Prinetti, 2009).

Os microdomínios lipídicos têm sido demonstrado não somente em células intactas, mas também em organismos vertebrados vivos, como nos embriões de zebrafish (Owen et al, 2012). Diversas técnicas associadas a microscopia de fluorescência são usadas para o estudo da heterogeneidade das membranas celulares incluindo: FRAP (fluorescence recovery after photobleaching); FCS (fluorescence correlation spectroscopy); FRET (fluorescence resonance energy transfer); SFTM (single fluorophore tracking microscopy); SPT (single-particle tracking) e STED (stimulated emission depletion farfield fluorescence nanoscopy). Os resultados obtidos com essas técnicas confirmam que a distribuição de moléculas na superfície celular não é randômica levando ao entendimento da organização hierárquica da membrana em células vivas. E ainda, reforça que os domínios da membrana plasmática são pequenos, estruturalmente dinâmicos e ativamente formados. Estas técnicas demonstram ainda que estes microdomínios podem ser organizados ou desorganizados rapidamente em respostas a diversos estímulos bioquímicos (Eggeling et al, 2009; Jacobson et al, 2007; Owen et al, 2009; Rao \& Mayor, 2005).

A identificação, caracterização e quantificação das proteínas presentes em uma amostra complexa, como os lipid rafts, tem sido objeto de vários estudos proteômicos (Bini et al, 2003; Pike et al, 2009; Zheng et al, 2009). Entretanto, os desafios enfrentados nestes trabalhos são diversos, como por exemplo: a quantidade de proteínas nas amostras, as técnicas de purificação e as dificuldades de análise de proteínas com domínios transmembrana por técnicas convencionais de espectrometria de massas (MS). As técnicas usadas no estudo de proteínas incluem métodos baseados em anticorpos, como immunoblotting e microscopia de imunofluorescência, bem como, proteomas baseados em MS. Os aparelhos modernos de MS disponíveis são altamente sensíveis e podem facilmente identificar centenas ou milhares de 
proteínas nos lipid rafts, porém não existe uma técnica que permita validar e verificar tão rapidamente estas várias proteínas identificadas (Foster \& Chan, 2007, Zheng \& Foster, 2009).

Os lipid rafts tem um papel relevante na fisiologia celular que está relacionado com a formação dos complexos de sinalização, onde ocorrem as etapas iniciais da transdução de sinal em mastócitos e outras células do sistema imune. Os microdomínios lipídicos são responsáveis pela formação e estabilização de microarranjos na membrana plasmática que servem como plataformas para a agregação de receptores, proteínas e enzimas envolvidas em diversos processos de ativação e sinalização celular, estando em intima associação ao citoesqueleto (Cebecauer et al, 2009; Gilfiilan \& Tkaczyk, 2006; Holowka et al, 2005; Masserini et al, 1999; Pizzo et al, 2004). Os lipid rafts são importantes sítios para a interação proteína-proteína mediada por proteínas tirosina quinases e que estão envolvidas no início das vias de sinalização mediadas por receptor, dados que já foram comprovados por estudos proteômicos destes microdomínios lipídicos em células do sistema imune como, por exemplo, neutrófilos e linfócitos T e B (Feuk-Lagerstedt et al, 2007; Foster et al, 2003; Wollscheid, 2004).

Em mastócitos não estimulados o receptor FcєRI está homogeneamente disperso na membrana plasmática. Imediatamente após o intercruzamento dos FceRIs, o receptor e os componentes do complexo de sinalização, incluindo LAT, são translocados para regiões de lipid rafts da membrana plasmática (Holowka \& Baird, 2001; Rivera et al, 2001; Stauffer \& Meyer, 1997; Wilson et al, 2000). Sendo assim, o importante papel dos lipid rafts nas etapas iniciais de transdução de sinal em mastócitos fazem destes microdomínios da membrana plasmática um alvo importante para a caracterização proteômica. 


\section{GANGLIOSÍDEOS DERIVADOS DO GD1b}

As membranas celulares são estruturas altamente organizadas com níveis múltiplos e multi-dimensionais de organização, sendo os lipídicos componentes ativos nestas estruturas. Os gangliosídeos são glicoesfingolipídeos anfipáticos presentes nas membranas celulares de todos os eucariotos. Esses glicoesfingolipídeos são caracterizados pela presença em quantidades variáveis de resíduos de açúcar contendo grupos carboxil, coletivamente conhecidos como ácido siálico (NANA), o que lhes confere um forte caráter polar. Devido à alta variabilidade das cadeias de seus oligossacarídeos e a heterogeneidade de seus motivos hidrofóbicos, os gangliosídeos representam uma grande família de compostos (Cantù, et al, 2011; Hakomori, 1993; Ikami et al, 2000).

Os gangliosídeos são componentes ativos da monocamada externa da membrana plasmática e desempenham papéis importantes em diversos eventos biológicos, como por exemplo: adesão, diferenciação e proliferação celular, resposta imune, regulação da morfologia celular, progressão tumoral, e funcionam também como receptores para outras células ou para toxinas bacterianas e vírus (Cantù et al, 2011; Sekino-Suzuki et al., 2013). Algumas doenças também estão relacionadas aos ganglisídeos, tais como: viroses, infecções bacterianas e doenças lisossomais como Gaucher, Tay-Sachs, Fabry, gangliosidoses. As neoplasias malignas expressam quantidades excessivas de glicoesfingolipídeos, os quais bloqueiam a capacidade do sistema imune de reconhecer as células cancerosas (Birklé et al, 2003; Hakomori \& Handa, 2015; Radin, 1999).

Os gangliosídeos são sintetizados no complexo de Golgi pela adição ordenada, etapa por etapa, de açúcares à ceramida hidrofóbica. Uridina difosfato glicose (UDPglicose), uridina difosfato galactose (UDP-galactose) e uridina difosfato (UDP)- $N$ - 
acetilgalactosamina são doadores ativos desses açúcares, assim como o derivado citidina monofosfato (CMP) e do $N$-acetilneuramínico. O CMP- $N$-acetilneuramínico é sintetizado a partir de citidina trifosfato (CTP) e $N$-acetilneuramínico. A estrutura do gangliosídeo resultante é determinada pela especificidade das glicosiltransferases da célula (Stryer, 2004). O transporte dos gangliosídeos do seu sítio de síntese no complexo de Golgi para a membrana plasmática ocorre via vesículas membranosas e/ou através de uma proteína transportadora (Gammon \& Ledeen, 1985).

Devido as suas características estruturais os gangliosídeos são importantes para a organização e para a regulação de eventos biológicos que se originam na membrana plasmática, principalmente nos microdomínios lipídicos onde os gangliosídeos são componentes fundamentais e atuam como moduladores da sinalização de vários tipos celulares, incluindo os mastócitos (Jou et al, 2006; Martini et al, 2002; Oliver et al, 2007; Simons \& Gerl, 2010).

Os gangliosídeos podem modular a função de receptores na superfície celular, como os receptores para o fator de crescimento derivado de plaquetas (PDGF), para o fator de crescimento epidérmico (EGF) e para a insulina, impedindo a dimerização induzida pelo ligante, a qual é crítica para a sinalização através desses receptores (Hanai et al, 1988; Weis \& Davis, 1990).

Outro exemplo do papel dos gangliosídeos na distribuição de proteínas envolvidas na sinalização celular é o dos gangliosídeos $\mathrm{GD}_{3}$ em neurônios cerebelares. Na investigação da associação de gangliosídeos com proteínas específicas do desenvolvimento do sistema nervoso central, o $\mathrm{GD}_{3}$ co-imunopreciptou com as proteínas PTK Lyn e a subunidade $\alpha$ da proteína heterotrimérica Go. O intercruzamento de gangliosídeos $\mathrm{GD}_{3}$ pelo anticorpo R24 induz a ativação de Lyn e a fosforilação de Cbp (C-terminal src kinase binding portein) nos lipid rafts dos neurônios cerebelares. A Cbp 
é uma fosfoproteína transmembrana implicada na regulação das PTKs recrutando Csk, uma proteína reguladora negativa de PTKs, para os lipid rafts. A Cbp também é fosforilada por Lyn em mastócitos. O tratamento destes neurônios com mAb anti-GD 1 b (GGR12) induz a fosforilação de $\mathrm{Cbp}$, sugerindo que não só $\mathrm{GD}_{3}$, mas também outros gangliosídeos estão envolvidos na via de sinalização dos neurônios (Sekino-Suzuki et al, 2013).

Os gangliosídeos derivados do $\mathrm{GD}_{1 \mathrm{~b}}$ foram identificados como componentes estruturais dos lipid rafts da superfície das células da linhagem de mastócitos de rato RBL-2H3 (Figura 4) (Sheets et al, 1999), através da utilização do anticorpo monoclonal (mAb) AA4, que reconhece especificamente os gangliosídeos derivados de GD $1 \mathrm{~b}$ exclusivos da superfície de mastócitos de rato e camundongos (Guo et al, 1989; Jamur et al, 2005; Jamur et al, 1997; Oliver 1992).

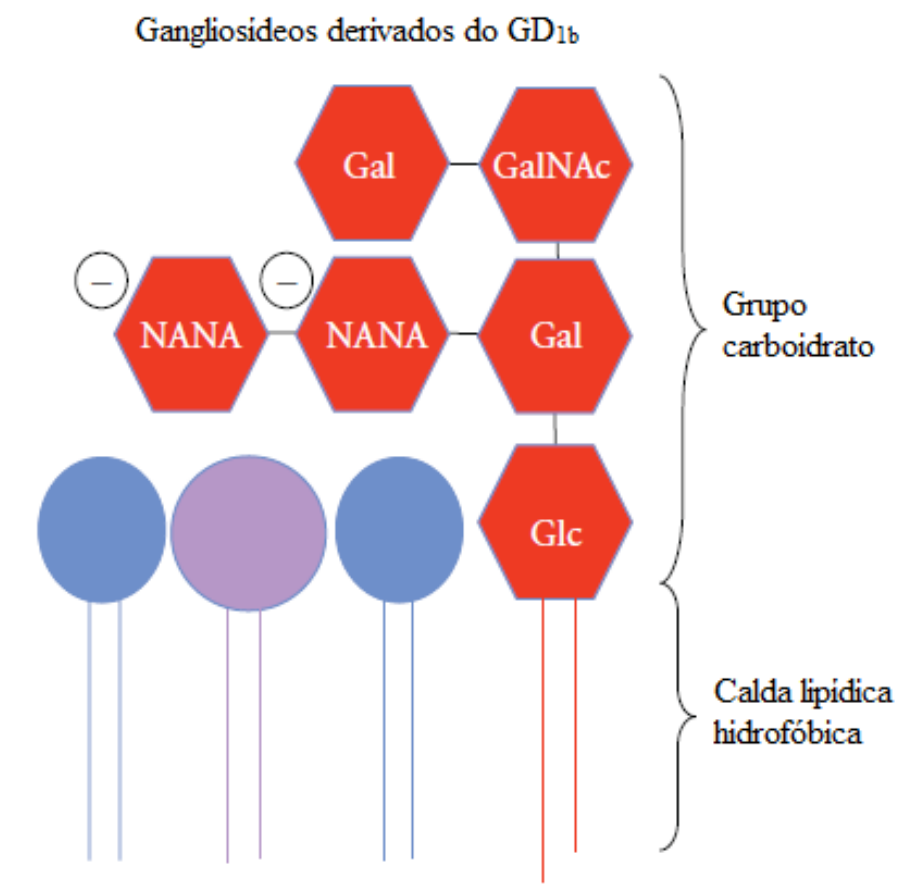

Figura 4. Representação esquemática do gangliosídeo GD1b. O gangliosídeo GD Gb $_{1 b}$ composto por grupo cabeça de carboidrato e um calda lipídica hidrofóbica. Gal, galactose; GalNAc, $N$-acetilgalactosamina; Glc, glicose; NANA, ácido $N$-acetilneuramínico. (Adaptado de Silveira e Souza et al., 2011). 
Os gangliosídeos derivados do $\mathrm{GD}_{1 \mathrm{~b}}$ são encontrados próximos ao FceRI e coprecipitam com Lyn. A associação entre FceRI, Lyn e os gangliosídeos formam um complexo de sinalização importante para a transdução de sinal em mastócitos (Minoguchi et al, 1994; Oliver et al, 2007; Pyenta et al, 2001; Sheets et al, 1999a; Swaim et al, 1994).

O intercruzamento dos gangliosídeos derivados do $\mathrm{GD}_{1 \mathrm{~b}}$, pelo mAb AA4 promove uma ativação parcial dos mastócitos, sendo as mudanças morfológicas e bioquímicas nestas condições similares àquelas observadas pela ativação via FceRI. As alterações bioquímicas incluem o aumento intracelular de cálcio, a hidrólise de fosfatidilinositol, a redistribuição de proteína quinase $\mathrm{C}$, as fosforilações das subunidades $\beta$ e $\gamma$ do FceRI, bem como a ativação da fosfolipase $C \gamma 1$, Lyn e Syk. Entretanto ocorre a inibição da liberação da histamina de modo dose e tempo de exposição dependente (Figura 5) (Basciano et al, 1986; Oliver et al, 1992; Swaim et al, 1994; Stephan et al, 1997).
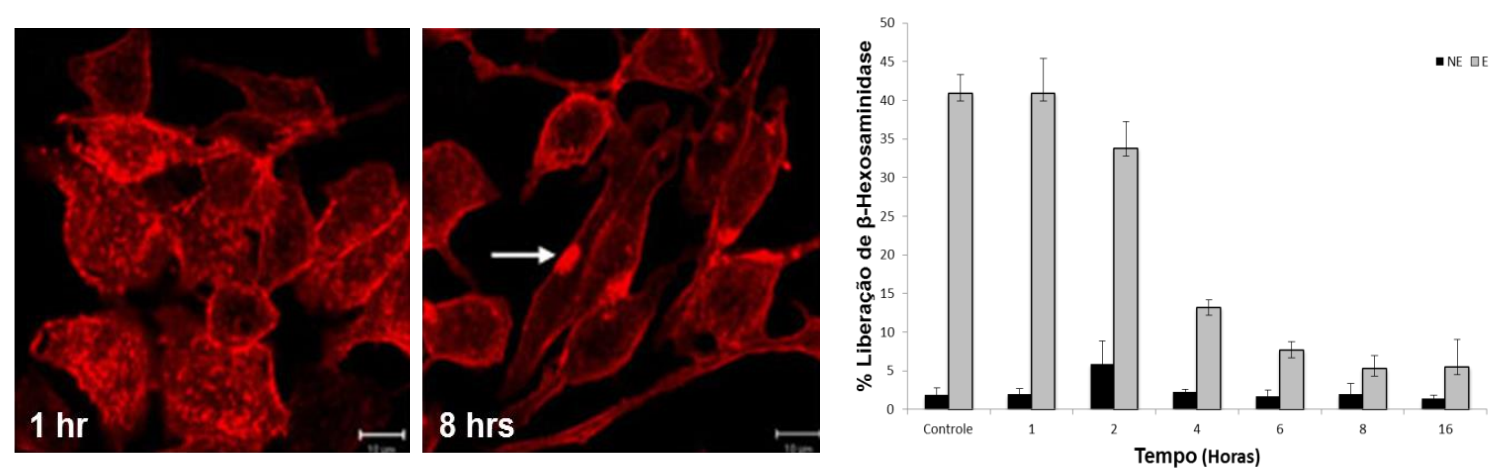

Figura 5. Efeito da agregação dos gangliosídeos derivados de GD $1 \mathrm{~b}$ na liberação de

及-hexosaminidase. Após 1 hora de incubação com mAb AA4 os gangliosídeos ainda estão dispersos na superfície de mastócitos da linhagem RBL-2H3. Após 8 horas de incubação com mAb AA4 os gangliosídeos formam agregados (caps, setas) na superfície celular. A formação de caps está relacionada com a diminuição da liberação de $\beta$ hexosaminidase.

O uso de linhagens de mastócitos RBL-2H3 deficientes em gangliosídeos derivados do $\mathrm{GD}_{1 \mathrm{~b}}$ confirmou que a associação do FceRI com os gangliosídeos é essencial para a 
organização dos lipid rafts e, consequentemente, para a transdução de sinal via FceRI. Portanto, os gangliosídeos derivados do $\mathrm{GD}_{1 \mathrm{~b}}$ são essenciais na formação do complexo de sinalização, em lipid rafts, para que ocorra a transdução do sinal em mastócitos (Silveira e Souza et al, 2008; Silveira e Souza et al, 2010). A presença de FcદRI e dos gangliosídeos derivados do GD $1 \mathrm{~b}$ no complexo de sinalização foi demonstrada através da endocitose de ambos em uma mesma vesícula. O FceRI e os gangliosídeos derivados do $\mathrm{GD}_{1 b}$ permanecem juntos durante o tráfego intracelular e são encontrados em um mesmo lisossomo (Mazucato et al., 2011).

Apesar dos gangliosídeos serem essenciais para a organização dos lipid rafts e para a liberação de mediadores pré-formados, pouco se conhece a respeito do seu papel na liberação dos mediadores neo-sintetizados e neoformados bem como sua relação com as proteínas presentes nos microdomínios lipídicos e associadas às etapas iniciais da transdução do sinal de mastócitos (Mazucato et al, 2011; Rivera et al, 2001; Silveira e Souza et al, 2008; Silveira e Souza et al, 2011).

O entendimento sobre o papel dos gangliosídeos na via de ativação de mastócitos trará novas perspectivas de intervenção neste processo podendo levar a novos alvos terapêuticos envolvidos em processos alérgicos e inflamatórios, bem como nas demais doenças em que os gangliosídeos estão envolvidos. 
OBJETIVOS 


\section{OBJETIVOS}

\section{OBJETIVO GERAL}

- Caracterizar o papel dos gangliosídeos derivados do $\mathrm{GD}_{1 \mathrm{~b}}$ na via de sinalização de mastócitos.

\section{OBJETIVOS ESPECÍFICOS}

- Investigar se o intercruzamento dos gangliosídeos derivados do $\mathrm{GD}_{1 \mathrm{~b}}$ pelo $\mathrm{mAb}$ AA4 resulta na liberação de mediadores neo-sintetizados e neoformados.

- Investigar o papel dos gangliosídeos derivados do $\mathrm{GD}_{1 \mathrm{~b}}$ na composição e na organização dos lipid rafts. 


\section{MATERIAL E MÉTODOS}

\section{CUlTuRa de CÉlulas}

Foram utilizadas células da linhagem de mastócitos de rato RBL-2H3 (Morita \& Siraganian, 1981) e as linhagens transgênicas estáveis derivadas de RBL-2H3:

- VB9 é uma linhagem repórter para a ativação do fator de transcrição NFAT e contém três sítios de ligação para NFAT, em tandem, fusionados a eGFP (Enhanced GFP) (Grodzki et al, 2009).

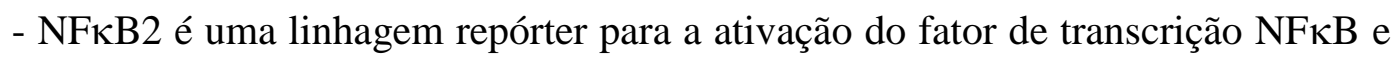
contém quatro cópias do sítio de ligação para NFאB localizado upstream do promotor mCMV, que regula a expressão de GFP dependente da ativação de NFкB. Estas células foram gentilmente cedidas pelo Dr. Reuben P. Siraganian - National Institutes of Health (NIDCR-NIH), Bethesda, MD, EUA.

- C4A2 é uma linhagem Syk ${ }^{-/-}$(Zhang et al, 2007).

- IH10 é derivada de C4A2 e é uma linhagem $\left(\mathrm{Syk}^{-/}\right)$repórter para a ativação do fator de transcrição NFAT contendo três sítios de ligação para NFAT, em tandem, fusionados a eGFP. Estas células foram gentilmente cedidas pelo Dr. Reuben P. Siraganian - NIDCR-NIH.

- IC2 é derivada de C4A2 e é uma linhagem $\left(\mathrm{Syk}^{-/-}\right)$repórter para a ativação do fator

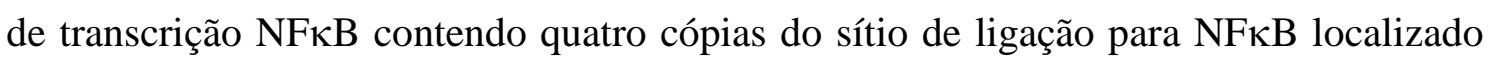
upstream do promotor mCMV que regula a expressão de GFP dependente da ativação de NFкB (de Castro et al, 2010).

As linhagens celulares foram cultivadas em meio essencial de Eagle modificado por Dulbecco - DMEM (Invitrogen, Gibco, Carlsbad, CA, EUA), suplementado com $15 \%$ de soro fetal bovino (Sigma-Aldrich, St. Louis, Missouri, EUA), $1 \%$ de 
antibiótico/antimicótico (Invitrogen), como previamente descrito (Basciano et al, 1986; Pierini et al, 1996) e mantidas em atmosfera úmida contendo $5 \%$ de $\mathrm{CO}_{2}$ a $37^{\circ} \mathrm{C}$. Para as linhagens repórteres, o antibiótico geneticina (G418, Geneticin ${ }^{\circledR}$, Life Technologies, Grand Island, NY, EUA) na concentração final de $500 \mu \mathrm{g} / \mathrm{mL}$ foi adicionado ao meio com a finalidade de manter a seleção das células GFP positivas.

As células foram monitoradas com o auxílio de microscópio invertido DIAVERT Leitz (Leica Microsystemns, Wetzlar, Alemanha). Quando 90\% confluentes, as células foram removidas dos frascos de cultivo utilizando-se Tripsina-EDTA (Invitrogen) por 10 minutos a $37^{\circ} \mathrm{C}$, em atmosfera úmida contendo $5 \%$ de $\mathrm{CO}_{2}$. Em seguida, as células foram centrifugadas a $200 \mathrm{xg}$ por cinco minutos, o sobrenadante foi descartado e o sedimento ressuspendido em meio de cultura para posterior quantificação e padronização do número de células.

\section{ANTICORPOS}

\section{Anticorpos Primários:}

- anticorpo monoclonal (mAb) AA4 (gentilmente cedido pelo Dr. Reuben P. Siraganian - NIDCR-NIH) específico para os gangliosídeos derivados do GD 1 b da superfície de mastócitos de rato e de camundongo (Basciano et al, 1986; Guo et al, 1989). Este anticorpo foi produzido a partir da imunização de camundongos com as células RBL2H3 e foi purificado do fluido ascítico pela precipitação com sulfato de amônio, seguido por cromatografia de troca iônica (DEAE) “Gama G Bind Plus" (Pharmacia, Upsala, Suécia).

- mAb IgE anti-TNP (fluido ascítico, gentilmente cedido pelo Dr. Reuben P. Siraganian - NIDCR-NIH) foi utilizado para a sensibilização das células, em experimentos de ativação celular e liberação de mediadores. 
- anticorpo anti subunidade $\beta$ do FcعRI, foi utilizado na concentração de $1 \mu \mathrm{g} / \mathrm{mL}$ em experimentos de Western Blot e Slot Blot. Este anticorpo foi gentilmente cedido pelo Dr. Reuben P. Siraganian - NIDCR-NIH).

- mAb de camundongo anti-CD32 (FC $\gamma$ RII) foi utilizado na concentração de 0,125 $\mu \mathrm{g} / \mathrm{mL}$ em experimentos de Western Blot e Slot Blot (BD Biosciences Pharmingen, San Jose, CA, EUA).

- anticorpo policlonal de coelho anti-Lyn $(0,125 \mu \mathrm{g} / \mathrm{mL})$; anticorpo policlonal de coelho anti-Vav $(0,125 \mu \mathrm{g} / \mathrm{mL})$; anticorpo policlonal de coelho anti-Syk $(0,125 \mu \mathrm{g} / \mathrm{mL})$; anticorpo policlonal de cabra anti-LAT $(0,5 \mu \mathrm{g} / \mathrm{mL})$ e anticorpo policlonal de cabra antiTEX101 (2 $\mu \mathrm{g} / \mathrm{mL})$ (Santa Cruz, Biotechnology Inc, Santa Cruz, CA, EUA) foram utilizados em experimentos de Western Blot, Slot Blot e imunofluorescência. O anticorpo policlonal de cabra anti-TEX101 foi utilizado para detecção da proteína de rato TEC-21, pois TEC-21 é homóloga a TEX101.

- mAb de camundongo anti-Thy1 (5 $\mu \mathrm{g} / \mathrm{mL}) ; \mathrm{mAb}$ de coelho anti-vimentina $(0,25$ $\mu \mathrm{g} / \mathrm{mL}$ ) e mAb de coelho anti-RACK1 (2 $\mu \mathrm{g} / \mathrm{mL}$ ) (Abcam, Cambridge, UK) foram utilizados em experimentos de Western Blot, Slot Blot e Imunofluorescência.

\section{Anticorpos Secundários:}

- fragmento $\mathrm{F}(\mathrm{ab})^{2} 2$ de $\operatorname{IgG}$ de cabra anti-IgG de camundongo, conjugado com Alexa 594 (Invitrogen, Molecular Probes, Eugene, OR, EUA), foi utilizado na concentração de $0,6 \mu \mathrm{g} / \mathrm{mL}(1: 1.000)$.

- fragmento $\mathrm{F}(\mathrm{ab}){ }^{2} 2$ de IgG de cabra anti-IgG de coelho, conjugado com Alexa 488 (Invitrogen, Molecular Probes), foi utilizado na concentração de $0,6 \mu \mathrm{g} / \mathrm{mL}$ (1:1.000).

- fragmento $\mathrm{F}(\mathrm{ab}){ }_{2}{ }_{2}$ de IgG de jumento anti-IgG de cabra, conjugado com HRP (Horse Radish Peroxidase) (Jackson ImmunoResearch, West Groove, PA, EUA), foi utilizado na concentração de $0,04 \mu \mathrm{g} / \mathrm{mL}$ (1:20.000). 
- fragmento $\mathrm{F}(\mathrm{ab}){ }_{2}$ de IgG de jumento anti-IgG de camundongo, conjugado com HRP (Jackson ImmunoResearch), foi utilizado na concentração de 0,16 $\mu \mathrm{g} / \mathrm{mL}$ (1:5.000).

- fragmentos $\mathrm{F}(\mathrm{ab}){ }_{2}{ }_{2}$ de IgG de jumento anti-IgG de coelho, conjugado com HRP (Jackson ImmunoResearch), foi utilizado na concentração de 0,04 $\mu \mathrm{g} / \mathrm{mL}$ (1:20.000).

\section{ENSAIO DE ATIVAÇÃO DO FATOR DE TRANSCRIÇÃO NFAT}

Para investigar se o intercruzamento dos gangliosídeos derivados do $\mathrm{GD}_{1 \mathrm{~b}}$ pela ligação ao mAb AA4 resulta na ativação de NFAT e se esta ativação é dependente de Syk, as células GFP-repórteres VB9 $\left(\mathrm{Syk}^{+}\right)$e IH10 (Syk-) $\left(1 \times 10^{5}\right.$ células/poço) foram cultivadas em placas de 24 poços, contendo ou não, lamínulas de vidro com $13 \mathrm{~mm}$ de diâmetro, e, posteriormente, incubadas com mAb AA4. Para padronizar a concentração, inicialmente, as células foram incubadas com 1; 2,5; 5 e $10 \mu \mathrm{g} / \mathrm{mL}$ de mAb AA4 por 1 hora, a $37^{\circ} \mathrm{C}$, em seguida lavadas 2 vezes com meio de cultura e, posteriormente, incubadas por 15 horas a $37^{\circ} \mathrm{C}$ para se observar a expressão de NFAT-GFP. Como controle positivo, as células VB9 $\left(\mathrm{Syk}^{+}\right)$foram sensibilizadas pela adição de IgE antiTNP por 16 horas, a seguir, estimuladas via FceRI com $50 \mathrm{ng} / \mathrm{mL}$ de DNP 48 -HSA (SigmaAldrich) e examinadas para a expressão de NFAT-GFP 16 horas após o estímulo. As células VB9 $\left(\mathrm{Syk}^{+}\right)$e IH10 ( $\left.\mathrm{Syk}^{-}\right)$também foram usadas como controle positivo através do estímulo com $0,1 \mu \mathrm{g} / \mathrm{mL}$ de ionóforo de cálcio A23187 (Sigma-Aldrich), por 1 hora. As células foram lavadas com meio de cultura e, posteriormente, incubadas por 15 horas a $37^{\circ} \mathrm{C}$ para se observar a expressão de NFAT-GFP.

A expressão de GFP pelas células em resposta a ativação de NFAT foi analisada por microscopia de fluorescência e por citometria de fluxo. Para microscopia, as células foram fixadas em 2\% paraformaldeído (EM Sciences) em PBS por 20 minutos. As lamínulas foram lavadas rapidamente em água purificada em sistema Mili-Q (Millipore 
Corporation) e montadas sobre lâminas de vidro (Knittel Glase) com Fluoromount G (EM Sciences). A expressão de GFP pelas células em resposta a ativação de NFAT foi analisada por microscopia de fluorescência em microscópio Nikon Eclipse 800, equipado com câmera digital DXM 1200 Nikon (Nikon Instruments Inc, Melville, NY, EUA). Para citometria de fluxo, as células foram tripsinizadas por 10 minutos a $37^{\circ} \mathrm{C}$, transferidas para um tubo contendo DMEM completo, centrifugadas, lavadas com PBS e fixadas com 2\% paraformaldeído (EM Sciences) em PBS por 20 minutos sob agitação (rocker). Em seguida as células foram lavadas e ressuspendidas em PBS e analisadas pelo citômetro Guava Easy Cyte Mini System com auxílio do programa Cytosoft Blue (Guava Technologies Inc, Hayward, CA, EUA).

\section{ENSAIO DE ATIVAÇÃO DO FATOR DE TRANSCRIÇÃO NFkB}

Para investigar se o intercruzamento dos gangliosídeos derivados do $\mathrm{GD}_{1 \mathrm{~b}}$ pela ligação ao mAb AA4 resulta na ativação de NFאB e se esta ativação é dependente de Syk, as células GFP-repórteres $\mathrm{NF \kappa B} 2\left(\mathrm{Syk}^{+}\right)$e $\mathrm{IC} 2\left(\mathrm{Syk}^{-}\right)\left(1 \times 10^{5}\right.$ células/poço) foram cultivadas em placas de 24 poços, contendo ou não, lamínulas de vidro com $13 \mathrm{~mm}$ de diâmetro, e, posteriormente, incubadas com mAb AA4. Inicialmente, as células foram incubadas com $1 ; 2,5 ; 5$ e $10 \mu \mathrm{g} / \mathrm{mL}$ de $\mathrm{mAb}$ AA4 por 1 hora, a $37^{\circ} \mathrm{C}$, em seguida lavadas 2 vezes com meio de cultura e, posteriormente, incubadas por 5 horas a $37^{\circ} \mathrm{C}$ para se

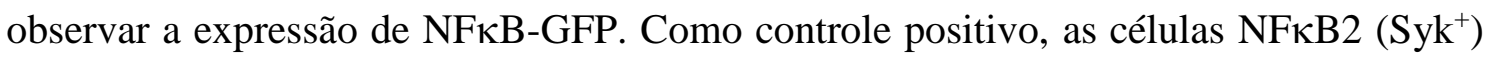
foram sensibilizadas pela adição de IgE anti-TNP por 16 horas e, então, estimuladas via FceRI com 50 ng/mL de $\mathrm{DNP}_{48}$-HSA (Sigma-Aldrich) e examinadas para a expressão de

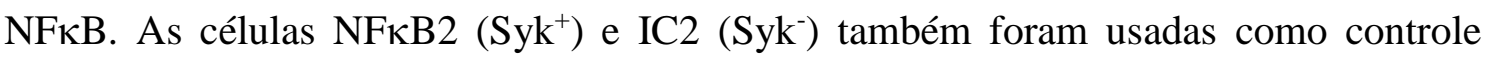
positivo através do estímulo com $0,1 \mu \mathrm{g} / \mathrm{mL}$ de ionóforo de cálcio A23187 (SigmaAldrich), por 1 hora. As células foram lavadas com meio de cultura e, posteriormente, 
incubadas por 5 horas a $37^{\circ} \mathrm{C}$ para se observar a expressão de NFкB-GFP. As células foram analisadas por microscopia de fluorescência e por citometria de fluxo, conforme descrito no item 3.

\section{SORTING DAS LINHAGENS REPÓRTERES VB9, NFkB2, IH10 E IC2}

Para realização dos estudos acima descritos, as células das linhagens GFPrepórteres VB9, NFkB2, IH10 e IC2 foram analisadas por citometria de fluxo com o intuito de selecionar clones com expressão máxima e homogênea de GFP em resposta à estimulação via FcદRI (VB9 e NFкB2) ou ionóforo de cálcio (Sigma-Aldrich) (IH10 e IC2), visto que estas linhagens são $\operatorname{Syk}^{-/-} \mathrm{e}$, portanto, não são ativadas via receptor FcعRI.

As células foram cultivadas por 16 horas em frascos de cultura T-75 (CostarCorning) como descrito no item 1. As células $\mathrm{VB} 9\left(\mathrm{Syk}^{+}\right)$e $\mathrm{NF \kappa B} 2\left(\mathrm{Syk}^{+}\right)$foram sensibilizadas pela adição de IgE anti-TNP por 16 horas, a seguir, estimuladas via FceRI com $50 \mathrm{ng} / \mathrm{mL}$ de $\mathrm{DNP}_{48}$-HSA (Sigma-Aldrich) e examinadas, respectivamente, para a expressão de NFAT-GFP 16 horas após o estímulo e para expressão de NFкB-GFP 6 horas após o estímulo. As células IH10 (Syk-) e IC2 (Syk) foram estimuladas com 0,1 $\mu \mathrm{g} / \mathrm{mL}$ de ionóforo de cálcio A23187 (Sigma-Aldrich), por 1 hora. As células foram lavadas com meio de cultura e posteriormente incubadas por, respectivamente, 15 horas e 5 horas a $37^{\circ} \mathrm{C}$ para se observar, respectivamente, a expressão de NFAT-GFP e NFкBGFP.

Após os diferentes tempos de estímulos, as células foram tripsinizadas e transferidas para tubos de $15 \mathrm{~mL}\left(1 \times 10^{7}\right.$ células/tubo $)$ contendo meio de cultura suplementado com $15 \%$ de SFB e centrifugadas $(200 \mathrm{x} g$ ) por 5 minutos, o sobrenadante foi desprezado e o sedimento celular ressuspendido em PBS. As células não estimuladas foram utilizadas como controle. As células foram analisadas e selecionadas em citômetro 
de fluxo JSAN (Japan-made Sorter, Analyzer; BD Biosciences, Heidelberg, Alemanha), com o FlowJo software (TreeStar Inc, San Carlos, CA, EUA).

Após o sorting, a porcentagem de células VB9-GFP ${ }^{+}$aumentou de 57\% para 96\%

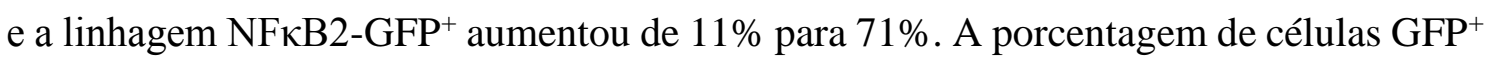
das linhagens $\mathrm{Syk}^{-/-}$IH10 e IC2, estimuladas com ionóforo de cálcio, também aumentaram após o sorting. As células IH10 passaram de 19\% para 64\% e as células IC2, aumentaram de $23 \%$ para $84 \%$, após a seleção por citometria de fluxo.

\section{ANÁLISE DA LIBERAÇÃO DE MEDIADORES NEO-SINTETIZADOS}

Para verificar se o intercruzamento dos gangliosídeos derivados do GD $1 \mathrm{~b}$ pelo mAb AA4 resulta na liberação de mediadores neo-sintetizados, os mastócitos RBL-2H3 (1×10 células/poço) foram cultivados e estimulados como descrito no item 3. Após 24 horas, o sobrenadante das células foi coletado, centrifugado a $200 \mathrm{xg}$ por 10 minutos a $4^{\circ} \mathrm{C}$ e as liberações de TNF- $\alpha$, IL-4 e IL-6 foram quantificadas por ensaio imunoenzimático utilizando, respectivamente, os kits BD OptEIA Rat TNF- $\alpha$ ELISA Set; BD OptEIA Rat IL-4 ELISA Set e BD OptEIA Rat IL-6 ELISA Set (BD Biosciences Pharmingen) de acordo com as instruções do fabricante.

\section{ANÁLISE DA LIBERAÇÃO DE MEDIADORES NEOFORMADOS}

Para verificar se o intercruzamento dos gangliosídeos derivados do $\mathrm{GD}_{1 \mathrm{~b}}$ pelo $\mathrm{mAb}$ AA4 resulta na liberação de mediadores neoformados e, se a liberação é mediada por Syk,

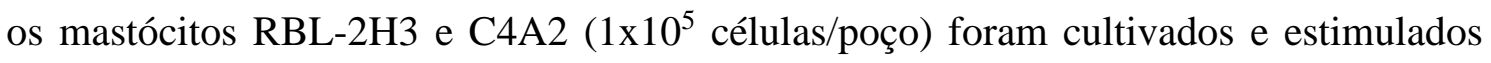
como descrito no item 3. Logo após o estimulo, o sobrenadante das células foi coletado, centrifugado a $200 \mathrm{xg}$ por 10 minutos a $4^{\circ} \mathrm{C}$ e as liberações de LTB4 e LTC4 foram determinadas por ensaio imunoenzimático utilizando, respectivamente, os kits 
Leukotrieno B4 EIA e Leukotrieno C4 EIA (Cayman Chemical Company, Ann Arbor, Michigan, EUA) de acordo com as instruções do fabricante.

\section{CARACTERIZAÇÃO DA COMPOSIÇÃO PROTEICA DOS LIPID RAFTS}

\subsection{Purificação de Lipid Rafts por fracionamento subcelular em gradiente de sacarose}

Os mastócitos RBL-2H3 $\left(2-5 \times 10^{7}\right)$ foram cultivados em placas de cultivo (CostarCorning Incorporated, NY, EUA) de 14,5 cm de diâmetro. Após 24 horas, as células foram incubadas com mAb AA4 por 1 hora, lavadas com meio completo e cultivadas por mais 7 horas a $37^{\circ} \mathrm{C}$ em atmosfera úmida contendo $5 \%$ de $\mathrm{CO}_{2}$ a $37^{\circ} \mathrm{C}$. Como controle, foram utilizadas células que não foram incubadas com mAb AA4. As células foram lavadas duas vezes com $20 \mathrm{~mL}$ de PBS gelado e removidas das placas com 2,6 mL de tampão de lise gelado [ $\mathrm{NaCl} 150 \mathrm{mM}$; MES (2-[N-Morpholino] ethanesulfonic acid, Sigma-Aldrich) $25 \mathrm{mM}$ pH 6.5; EDTA $5 \mathrm{mM}$; $\mathrm{Na}_{3} \mathrm{VO}_{4} 1 \mathrm{mM}$; PMSF (fluoreto de fenilmetilsulfonila-Sigma-Aldrich) $2 \mathrm{mM}$; coquetel inibidor de proteases (SigmaAldrich) 1:50 e Triton X-100 (Sigma-Aldrich) 0.05\% (v/v)]. Em seguida, a suspensão de células foi homogeneizada em homogeneizador de Dounce (30 strockes) e o homogenato foi colocado sobre 2,6 mL de sacarose 80\% (w/v) em solução de MNEV (NaCl 150 mM; MES $25 \mathrm{mM}$ pH 6.5; EDTA $5 \mathrm{mM}$ e $\left.\mathrm{Na}_{3} \mathrm{VO}_{4} 1 \mathrm{mM}\right)$ em tubo Beckman (13 mL) e misturada em vortex, de modo a conseguir uma solução $40 \%$ de sacarose. Sobre a sacarose $40 \%$, foram adicionados $5,2 \mathrm{~mL}$ de sacarose $30 \%(\mathrm{w} / \mathrm{v})$ em solução MNEV contendo coquetel inibidor de proteases 1:100 e PMSF $1 \mathrm{mM}$. Sobre a sacarose 30\%, foram adicionados 2,6 mL de sacarose 5\% (w/v) em solução de MNEV contendo coquetel inibidor de proteases 1:100 e PMSF $1 \mathrm{mM}$. As amostras foram então centrifugadas em ultracentrífuga Beckman (Beckman Instruments, Miami, Flórida, EUA), no rotor 40-Ti a 
$38.000 \mathrm{rpm}$ a $4^{\circ} \mathrm{C}$ com aceleração máxima, por 20 horas. Subsequentemente, 10 alíquotas de 1,3 mL foram coletadas ordenadamente a partir da porção superior do tubo, colocadas em gelo e estocadas em freezer $-80^{\circ} \mathrm{C}$.

\subsection{Slot Blot}

Após a purificação dos lipid rafts, alíquotas de $5 \mu \mathrm{L}$ de cada uma dessas frações foram imobilizadas em membranas Hybond (Amersham-Biosciences, Pittsburgh, PA, EUA) utilizando o aparelho de microfiltração a vácuo Bio Dot (Bio-Rad Laboratories, Inc, Hercules, CA, EUA). As membranas foram incubadas overnight, a $4^{\circ} \mathrm{C}$ para adsorção sobre as membranas. As membranas foram bloqueadas pela incubadas por 1 hora à temperatura ambiente em TBS/Tween $(\mathrm{NaCl} 150 \mathrm{mM}$, Tris- $\mathrm{HCl} 1 \mathrm{mM}$ pH 7,5 e 0,05\% de Tween-20, v/v) contendo 5\% de leite em pó desnatado (Nestlé, São Paulo, Brasil) ou 1\% de BSA (albumina de soro bovino; Sigma-Aldrich). Em seguida, para identificação das frações contendo gangliosídeos derivados do $\mathrm{GD}_{1 \mathrm{~b}}$, as membranas foram incubadas por 1 hora à temperatura ambiente com o anticorpo primário mAb AA4 $(2,5 \mu \mathrm{g} / \mathrm{mL})$. As proteínas associadas aos lipid rafts foram identificadas com os anticorpos: anti subunidade $\beta$ do FceRI; anti-FC $\gamma$ RII; policlonal de cabra anti-LAT; policlonal de coelho anti-Lyn; policlonal de coelho anti-Syk; policlonal de coelho anti-Vav; policlonal de cabra anti-TEX101; mAb de camundongo anti-Thy1; mAb de coelho anti-Vimentina e mAb de coelho anti-RACK1. Após a incubação, as membranas foram lavadas 5 vezes de 5 minutos com TBS/Tween e em seguida, incubadas por 30 minutos à temperatura ambiente com os anticorpos secundários conjugados com HRP (item 2). As membranas foram novamente lavadas, 5 vezes de 10 minutos, com TBS/Tween e a detecção por quimioluminescência realizada com o kit ECL - Enhanced Chemiluminescence (GE, Amersham-Biosciences, Uppasala, Suécia). 
Os Slot blots foram fotodocumentados utilizando o ImageQuant LAS 4000 (GE Healthcare, UK Ltd, Amersham, UK) e tiveram suas bandas quantificadas através da densidade óptica relativa (unidade arbitrária) utilizando o ImageJ 1.47t (National Institutes of Health, Bethesda, MD, USA).

\subsection{Extração, quantificação e Western Blot das proteínas presentes nas frações}

\section{de lipid rafts}

As frações contendo os lipid rafts (2-3) de cada condição foram agrupadas para obtenção do perfil proteico presente nestas frações. Inicialmente, cada amostra foi ressuspendida em 1,5 mL de $50 \mathrm{mM} \mathrm{NH}_{4} \mathrm{HCO}_{3}(\mathrm{pH} 7,9)$, transferidos para tubos Amicon ${ }^{\circledR}$ Ultra Centrifugal Filters 3K (50.000 rpm por 1 hora). O mesmo processo de lavagem foi repetido 5 vezes para remoção dos resíduos de detergente e para realizar a troca de tampão. Ao final, cada amostra foi ressuspendida em um volume final de $0,3 \mathrm{~mL}$ de $50 \mathrm{mM} \mathrm{NH}_{4} \mathrm{HCO}_{3}(\mathrm{pH} 7,9)$.

A quantificação das proteínas foi realizada com a adição de $200 \mu \mathrm{L}$ do reativo de Bradford (Bradford, 1976) por poço com incubação por 15 minutos à temperatura ambiente. A curva padrão foi realizada com 0,5-2 $\mu \mathrm{g}$ de BSA (Sigma-Aldrich) diluída em $20 \mu \mathrm{L}$ de água. A absorbância das amostras foi determinada em leitor de placa Power Wave X Plate Reader (Bio-Tek Instrument, Winooski, VT, EUA) com leitura em 595 nm.

Com o intuito de verificar a integridade das proteínas presentes nos extratos proteicos obtidos pela união das frações 2 e 3 do gradiente de sacarose e, a posteriori, para validação dos dados obtidos na análise proteômica foram diluídas $10 \mu \mathrm{g}$ de proteína de cada uma das condições analisadas em tampão de amostra (2\% SDS; $25 \%$ Glicerol e 0,0006\% de azul de bromofenol em tampão de tris- $\mathrm{HCl} 50 \mathrm{mM} \mathrm{pH} \mathrm{6,8)} \mathrm{e} \mathrm{fervidas} \mathrm{durante}$ 5 minutos. A eletroforese das proteínas foi realizada de acordo com o sistema de tampão descontínuo descrito por Laemmli \& Favre, 1973. As amostras foram aplicadas em géis de poliacrilamida 10\%. Na eletroforese foi utilizado tampão de corrida (Tris $25 \mathrm{mM}$; 
glicina $187 \mathrm{mM}$ pH 8,3 e SDS 0,1\%) em condições redutoras e dissociantes a $120 \mathrm{~V}$. Como marcador de migração eletroforética foi utilizado SeeBlue pre-stained marker (Invitrogen). Após a separação das proteínas através de SDS-PAGE, as bandas proteicas foram coradas com Coomassie Blue coloidal (Towbin et al, 1979). Para a coloração, o gel foi fixado por 1 hora em metanol, ácido acético e água (50:7:43) e corado com Coomassie blue coloidal (Neuhoff et al, 1988) por 16 horas. Em seguida o gel foi descorado com água Milli-Q e analisado quanto à presença e o peso molecular das bandas.

Para a validação dos dados obtidos na análise proteômica, quando necessário, o gel contento os perfis proteicos foi equilibrado em tampão para transferência (Tris $25 \mathrm{mM}$ pH 8,3; glicina 193 mM; etanol 20\% e SDS 0,1\%) e a eletrotransferência foi realizada segundo Towbin et al., 1979. O suporte de transferência foi colocado dentro de uma cuba de transferência de modo que a membrana de nitrocelulose ficasse voltada para o polo positivo. A eletrotransferência foi realizada a $35 \mathrm{~V}$ por 4 horas a temperatura ambiente. Após a eletrotransferência, as membranas de nitrocelulose foram coradas com Роисеau Red (Sigma-Aldrich).

Para a imunodetecção as membranas de nitrocelulose foram bloqueadas por 1 hora à temperatura ambiente, sob agitação suave, em TBS/Tween $(\mathrm{NaCl} 150$ mM; Tris-HCl 1 $\mathrm{mM}$ pH 7,5 e 0,05\% de Tween-20, v/v) contendo 5\% de leite em pó desnatado (Nestlé, São Paulo, Brasil) ou 1\% de BSA (Sigma-Aldrich). Em seguida, as membranas foram lavadas em TBS/Tween e incubadas com o anticorpo primário diluído em TBS/Tween por 1 hora à temperatura ambiente. Após a incubação as membranas foram novamente lavadas 5 vezes de 5 minutos com TBS/Tween e incubadas por 30 minutos à temperatura ambiente, com o anticorpo secundário conjugado com HRP (item 2). As membranas foram lavadas, novamente, 5 vezes de 10 minutos com TBS/Tween e a detecção por 
quimioluminescência realizada com o kit ECL - Enhanced Chemiluminescence (GE, Amersham-Biosciences).

Os Immunoblots foram fotodocumentados utilizando o ImageQuant LAS 4000 (GE Healthcare) e as bandas foram quantificadas através da densidade óptica relativa (unidade arbitrária), utilizando o ImageJ 1.47t (National Institutes of Health).

\subsection{Redução, alquilação e digestão das proteínas para análise NanoUPLC-MS}

Após a quantificação do extrato proteico e confirmação da integridade das proteínas, o total de $55 \mu \mathrm{g}$ de proteínas referente a cada condição experimental foi transferido para tubos de microcentrífuga e adicionados $10 \mu \mathrm{L}$ de carbonato de amônio na concentração de $50 \mathrm{mM}\left(\mathrm{NH}_{4}\right)_{2} \mathrm{CO}_{3}$ (Sigma-Aldrich) pH 8,5. Em seguida, $25 \mu \mathrm{L}$ de solução contendo $0.2 \%$ (v/v) do surfactante RapiGest (Waters-Micromass, Manchester, UK) foram adicionados as amostras, as quais foram agitadas em vortex e incubadas em banho seco por 15 minutos a $80^{\circ} \mathrm{C}$. Após a incubação, as amostras foram centrifugadas e reduzidas pela adição de $2,5 \mu \mathrm{L}$ de DTT (Ditiotreitol) $100 \mathrm{mM}$ por 30 minutos a $60^{\circ} \mathrm{C}$. Posteriormente, as amostras foram alquiladas pela adição de 2,5 $\mu 1$ de iodoacetamida 300 mM (GE, Healthcare) e incubadas por 30 minutos, a temperatura ambiente sob proteção da luz. A digestão enzimática foi realizada pela adição de $11 \mu \mathrm{L}$ de tripsina (Promega, Madison, WI, USA) em 50 mM de bicarbonato de amônio (Sigma-Aldrich), seguido de incubação por 16 horas a $37^{\circ} \mathrm{C}$. Após completa digestão, para hidrólise do surfactante, adicionou-se $11 \mu \mathrm{L}$ de ácido trifluoroacético 5\% (Sigma-Aldrich), seguido de agitação e incubação a $37^{\circ} \mathrm{C}$ por 90 minutos. Em seguida, as amostras foram centrifugadas (20817 $\mathrm{xg}$ ) por 30 minutos a $4^{\circ} \mathrm{C}$. Os sobrenadantes foram transferidos para tubos novos e as amostras foram secas em SpeedVac. 


\subsection{Análise NanoUPLC-MS ${ }^{E}$}

As amostras foram ressuspendidas em $49,5 \mu \mathrm{L}$ de formiato de amônio $20 \mathrm{mM}$ (Sigma-Aldrich) e $0,5 \mu \mathrm{L}$ do controle interno proteína enolase de fungo (Waters) foi adicionado aos peptídeos trípticos, antes de serem analisadas pelo NanoUPLC-MS ${ }^{\mathrm{E}}$. Para realizar a quantificação dos peptídeos, a concentração do padrão interno permaneceu em $100 \mathrm{fmol} / \mu \mathrm{L}$. As amostras foram transferidas para frascos Waters Total Recovery (Waters). Os peptídeos trípticos foram separados por cromatografia líquida em nano escala utilizando o cromatógrafo nanoACQUITY UPLC com tecnologia 2D (Waters) acoplado ao espectrômetro de massa Synapt $H D M S^{T M}$ (Waters). A primeira dimensão da cromatografia foi realizada em uma coluna XBridge BEH 130 C 18 Nanoease (5 $\mu \mathrm{m}, 300$ $\mu \mathrm{m}$ x $50 \mathrm{~mm}$; Waters) que permitiu o fracionamento dos peptídeos. O sistema foi mantido em fluxo de $2 \mu \mathrm{L} / \mathrm{min}$ com uma condição inicial de acetonitrila (ACN) de $3 \%$. Os peptídeos foram fracionados 10 vezes (F1-F10) utilizando diferentes gradientes lineares de concentrações de ACN. A segunda dimensão foi realizada pela eluição de cada fração a partir da coluna de aprisionamento de peptídeos e separadas em coluna NanoAcquity UPLC BEH $130 C 18(1,7 \mu \mathrm{m}, 100 \mu \mathrm{m}$ x $100 \mathrm{~mm}$; Waters). A coluna foi operada em fluxo de $0,9 \mu \mathrm{L} / \mathrm{min}$ a $35^{\circ} \mathrm{C}$. O sistema de cromatografia $2 \mathrm{D}$ é acoplado a um espectrômetro de massas Q-TOF-MS Synapt (Waters) onde ocorreu a aquisição dos dados de espectrometria de massas, o que permitiu a identificação e quantificação dos peptídeos. O padrão glufibrinopeptídeo foi usado como spray de referência da fonte NanoLockSpray. O espectrômetro foi operado em modo-V. Todas as análises foram realizadas com ionização nanoeletrospray no modo de íon positivo nanoESI $\left({ }^{+}\right)$com fonte NanoLockSpray. Os dados foram coletados com energia de colisão constante de $4 \mathrm{~V}$ durante o modo $\mathrm{MS}^{\mathrm{E}}$ de baixa energia, enquanto uma fase de 15 a $30 \mathrm{~V}$ de energia de 
colisão foi usada durante o modo de $\mathrm{MS}^{\mathrm{E}}$ de alta energia e as amostras foram analisadas em triplicata.

\subsection{Processamento de dados e identificação das proteínas}

Os espectros MS que foram obtidos do Nano-UPLC-MS ${ }^{\mathrm{E}}$ foram processados e examinados utilizando o ProteinLynx Global Server (PLGs) versão 2.4 (Waters). A largura do pico cromatográfico e a resolução MS TOF foram configuradas em modo automático. Os parâmetros de busca foram: taxonomia [Eukaryota (Rattus norvegicus)] com no máximo uma clivagem perdida. Foram adicionadas à busca modificações de carbamidometilação das cisteínas, acetilação N-terminal e oxidação de metioninas. Todas as pesquisas foram conduzidas usando o banco de dados Uniprot de Rattus norvegicus disponível em: (<http://www.uniprot.org/uniprot/?query=taxonomy:10116>). Os resultados foram importados para Microsoft Excel para análises posteriores.

A quantificação livre de marcação (Label-free quantitation - LFQ) foi realizada utilizando significance analysis of microarrays (SAM) (Grace and Nacheva, 2012). A razão mínima entre os resultados para LFQ foi de 2. O valor delta foi programado para 0,06. As proteínas up reguladas ou down reguladas foram definidas tendo a razão proteica de um fold chand 1,5 .

Os gráficos baseados nas anotações no Gene Ontology $(\mathrm{GO})$ e no número de acesso das proteínas presentes na lista UniProt Knowledgebase foram gerados pelo Software STRAP (Software Tool for Researching Annotations of Proteins). (<http://www.bumc.bu.edu/cardiovascularproteomics/cpctools/strap/〉). 


\section{IMUNOFLUORESCÊNCIA}

Os mastócitos RBL-2H3 foram cultivados $\left(4 \times 10^{4}\right)$ sobre lamínulas de vidro de 13 mm de diâmetro (Knittel Glase, Brauschweig, Alemanda) em placas de 24 poços (CostarCorning). Após 24 horas, as células foram incubadas com mAb AA4 por 1 hora, lavadas com meio completo e cultivadas por mais 7 horas a $37^{\circ} \mathrm{C}$ em atmosfera úmida contendo $5 \%$ de $\mathrm{CO}_{2}$ a $37^{\circ} \mathrm{C}$. Como controle, foram utilizadas células que não foram incubadas com mAb AA4. Para a imunomarcação das proteínas Lyn, as células foram fixadas em paraformaldeído 2\% (EM Sciences, Fort Washigton, PA, EUA) em PBS por 20 minutos à temperatura ambiente. Para a imunomarcação de vimentina, as células foram fixadas e permeabilizadas em paraformaldeído $2 \%$ em metanol por 5 minutos a $4^{\circ} \mathrm{C}$. Subsequentemente, as células foram lavadas 5 vezes com PBS e 1 vez com PSB contendo 0,1 M de glicina (Sigma-Aldrich) por 5 minutos. Em seguida, os sítios inespecíficos foram bloqueados através da incubação por 30 minutos com PBS contendo 1\% de BSA (Sigma-Aldrich) e $5 \mu \mathrm{g} / \mathrm{mL}$ de IgG da mesma espécie de animal onde foi produzido o anticorpo secundário, para bloquear os receptores para $\mathrm{IgG}$, também presentes na superfície dos mastócitos. Para a imunomarcação da proteína Lyn, as células foram permeabilizadas com $0,01 \%$ de Saponina (Sigma-Aldrich) adicionada na solução de bloqueio. Posteriormente, as células foram incubadas por 1 hora com os diferentes anticorpos primários diluídos em PBS com 1\% de BSA. Após esse período, as células foram lavadas 5 vezes de 5 minutos em PBS. Após 30 minutos de incubação com os anticorpos secundários, as células foram lavadas 10 vezes de 5 minutos com PBS e, em seguida, lavadas com água purificada em sistema Mili-Q (Millipore Corporation, Bedford, MA, EUA) e montadas sobre lâminas de vidro (Knittel Glase) com Fluoromount G (EM Sciences). No controle foi omitido o anticorpo primário. O material foi observado em microscópio confocal Leica Super-Resolution TCS SP8 STED 3X. Alguns espécimes 
foram observados em microscópio confocal Zeiss modelo LSM 780 Multiphoton microscopy (Carl Zeiss, Heidelberg, Alemanha) e analisados utilizando o ImageJ $1.47 t$ (National Institutes of Health).

\section{ANÁLISE ESTATÍSTICA}

Os resultados obtidos foram avaliados estatisticamente, através da análise de variância ANOVA de uma via, teste TUKEY e a diferença estatística foi considerada significante quando $\mathrm{p}<0,05$. A análise foi realizada utilizando-se o software GraphPad Prism 5 (GraphPad Software, San Diego, CA). 
RESULTADOS 


\section{RESULTADOS}

\section{O INTERCRUZAMENTO DOS GANGLIOSÍDEOS DERIVADOS DO GD PELO mAb AA4 PROMOVE A ATIVAÇÃO DOS FATORES DE TRANSCRIÇÃO NFAT E NFאB}

O intercruzamento dos gangliosídeos derivados do GD 1 , pelo mAb AA4 promove uma ativação parcial dos mastócitos, sendo as mudanças morfológicas e bioquímicas nestas condições similares àquelas observadas pela ativação via FceRI, mas sem liberação dos mediadores pré-formados (Basciano et al, 1986; Oliver et al, 1992; Stephan et al, 1997; Swaim et al, 1994). A estimulação dos mastócitos via FcعRI resulta na ativação dos fatores de transcrição NFAT (Nuclear factor of activated T-cells) e NFкB (Nuclear factor kB) (Benhamou \& Siraganian, 1992; Metcalfe et al, 1997). Estes fatores de transcrição se ligam a regiões regulatórias de genes envolvidos na produção de citocinas relacionadas à inflamação, resultando na expressão e liberação dos mediadores neosintetizados (Cook et al, 2004; Gilfillan \& Tkaczyk, 2006). Dados da literatura mostram que Syk é essencial para a ativação, mediada pelo receptor FcદRI, dos fatores de transcrição, como NFAT, em mastócitos (Grodzki et al, 2009). Assim sendo, neste estudo investigamos mastócitos RBL-2H3 incubados por uma hora com o mAb AA4 e mais 7 horas sem o anticorpo. Nestas condições os gangliosídeos derivados do GD 1 b estavam agregados, então, investigamos se o intercruzamento pela agregação dos gangliosídeos

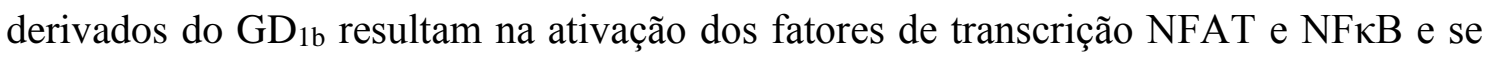
esta ativação é mediada por Syk. 


\subsection{NFAT}

Para investigar se o intercruzamento dos gangliosídeos derivados do $\mathrm{GD}_{1 b}$ pelo mAb AA4 resulta na ativação do NFAT foram utilizadas as linhagens GFP-repórter VB9 $\left(\mathrm{Syk}^{+}\right)$e IH10 $\left(\mathrm{Syk}^{-}\right)$. Os resultados mostram que o intercruzamento dos gangliosídeos derivados do $\mathrm{GD}_{1 b}$ pelo mAb AA4 resulta na ativação do fator de transcrição NFAT em células VB9 $\left(\mathrm{Syk}^{+}\right)$, onde 35\% das células são $\mathrm{GFP}^{+}$. As células VB9, ativadas via FceRI (controle positivo) foram 91\% $\mathrm{GFP}^{+}$(Figura 6).
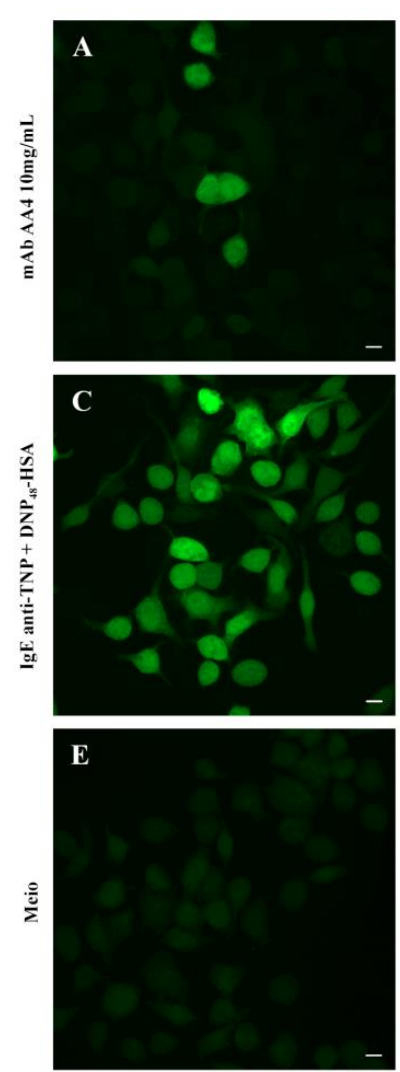
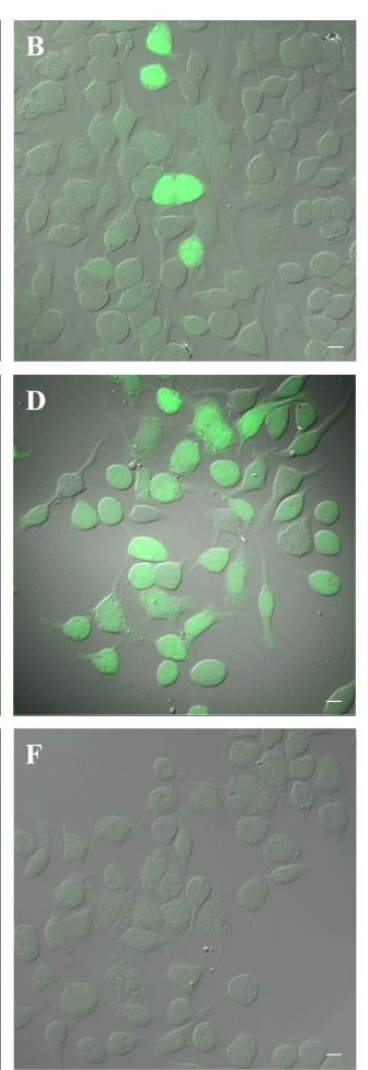
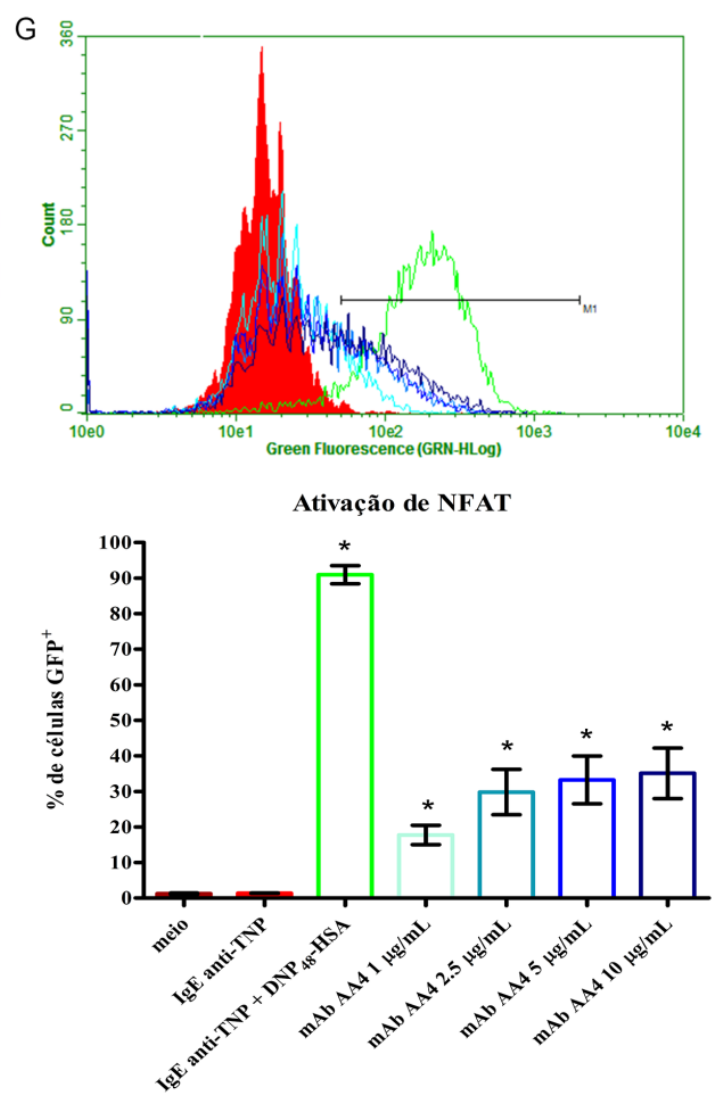

Figura 6. O intercruzamento dos gangliosídeos derivados do GD Gb $_{1 b}$ pela ligação ao mAb AA4 resulta na ativação do fator de transcrição NFAT. (A) Células VB9 estimuladas com $10 \mu \mathrm{g} / \mathrm{mL}$ do mAb AA4 expressam GFP, microscopia de fluorescência; (B) Sobreposição do mesmo campo mostrado em A com DIC; (C) Células VB9 sensibilizadas com IgE anti-TNP e estimuladas com DNP 48 -HSA são GFP+; (D) Mesmo campo mostrado em C, observado com DIC; (E) Controle: células não estimuladas; (F) mesmo campo mostrado em E, observado com DIC; Barra: $10 \mu \mathrm{m}$; (G) Citometria de fluxo de células VB9 estimuladas ou não. ${ }^{*} P<0.0001$. Os dados representam a média \pm desvio padrão de 4 experimentos independentes. 
Por outro lado, não ocorre ativação de NFAT na linhagem IH10 (Syk) após o intercruzamento dos gangliosídeos derivados do $\mathrm{GD}_{1 \mathrm{~b}}$ pelo mAb AA4. Estes resultados mostraram que a ativação do fator de transcrição NFAT através do intercruzamento dos gangliosídeos derivados do GD 1 belo mAb AA4 é dependente de Syk (Figura 7).
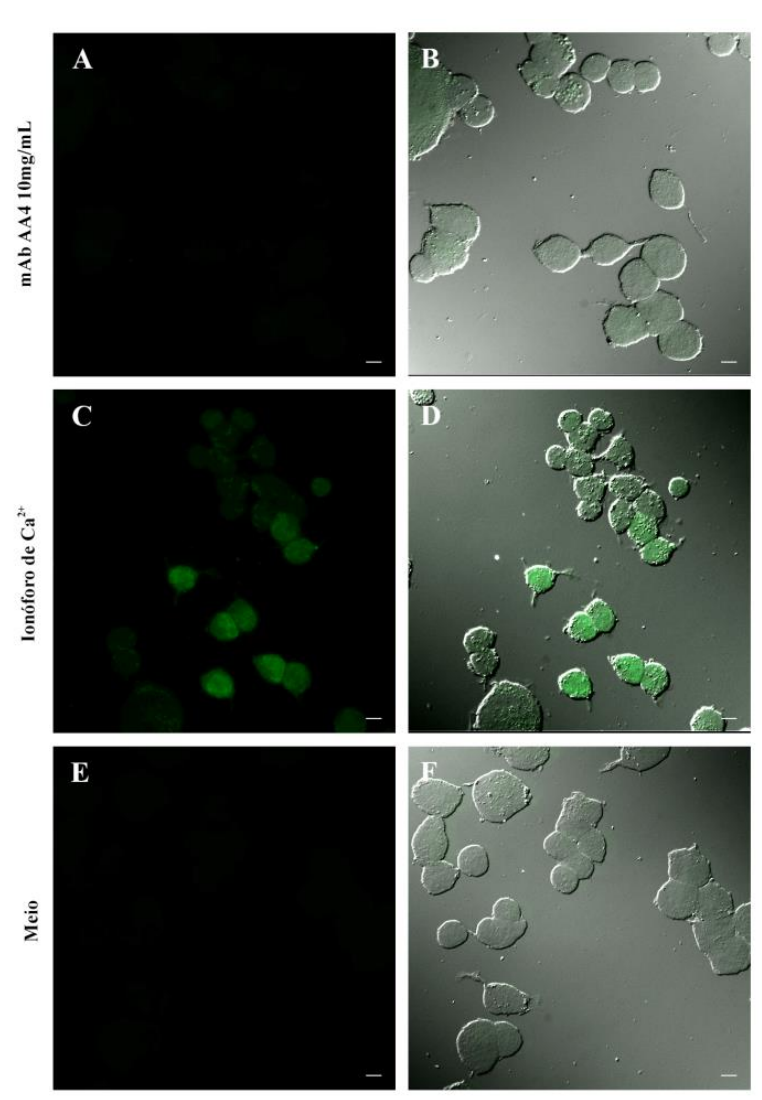

Figura 7. $O$ intercruzamento dos gangliosídeos derivados do GD1b pela ligação ao mAb AA4 é dependente da PTK Syk para ativação do fator de transcrição NFAT.

(A) Células IH10 estimuladas com $10 \mu \mathrm{g} / \mathrm{mL}$ do mAb AA4 não expressão GFP, microscopia de fluorescência; (B) Sobreposição do mesmo campo mostrado em A com DIC; (C) Células IH10 estimuladas com ionóforo de cálcio são GFP ${ }^{+}$; (D) Mesmo campo mostrado em C, observado com DIC; (E) Controle: células não estimuladas; (F) mesmo campo mostrado em E, observado com DIC; Barra: $10 \mu \mathrm{m}$; (G) Citometria de fluxo de células IH10 estimuladas ou não. ${ }^{*} P<0.0001$. Os dados representam a média \pm desvio padrão de 4 experimentos independentes. 


\subsection{NFKB}

Para investigar se o intercruzamento dos gangliosídeos derivados do $\mathrm{GD}_{1 b}$ pelo mAb AA4 resulta na ativação do fator de transcrição NFkB foram utilizadas as linhagens GFP-repórteres NFkB2 $\left(\mathrm{Syk}^{+}\right)$e IC2 $\left(\mathrm{Syk}^{-}\right)$. Os resultados mostram que o intercruzamento dos gangliosídeos derivados do $\mathrm{GD}_{1 \mathrm{~b}}$ pelo ao mAb AA4 resulta na ativação de $\mathrm{NF \kappa B}$ em células $\mathrm{NF \kappa B} 2\left(\mathrm{Syk}^{+}\right)$, onde $38 \%$ das células são $\mathrm{GFP}^{+}$. As células NFkB2 $\left(\mathrm{Syk}^{+}\right.$), ativadas via FceRI (controle positivo) foram 57\% $\mathrm{GFP}^{+}$(Figura 8).
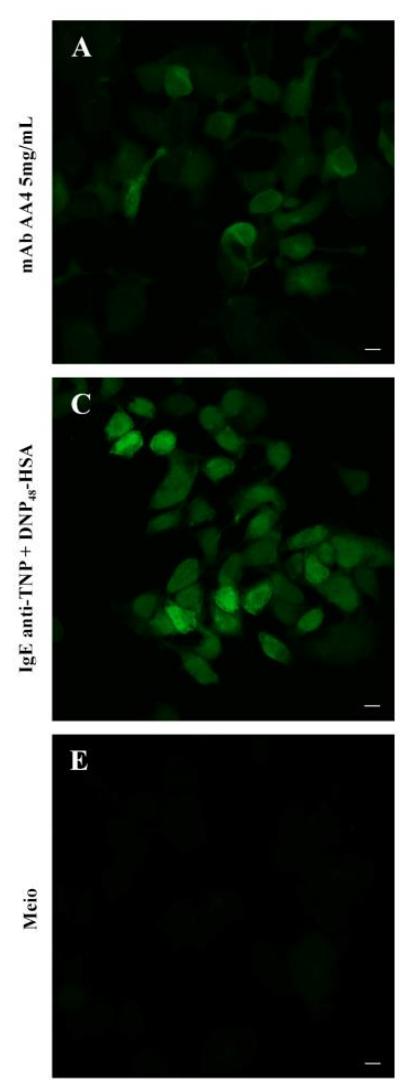
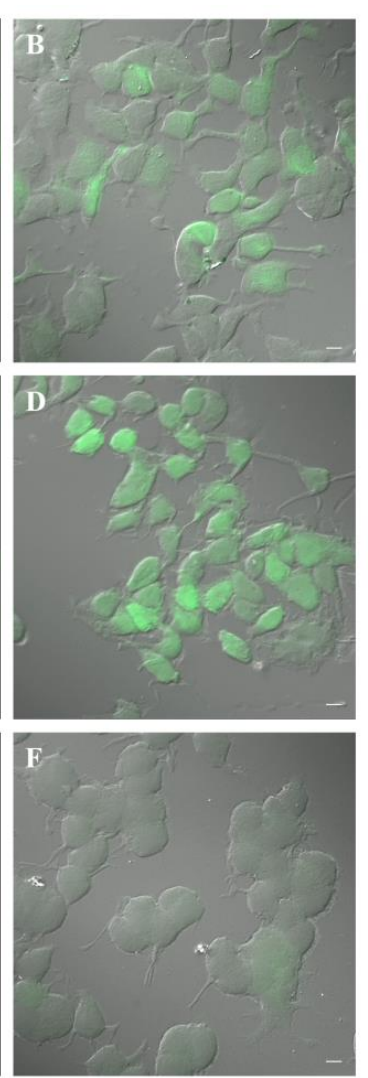
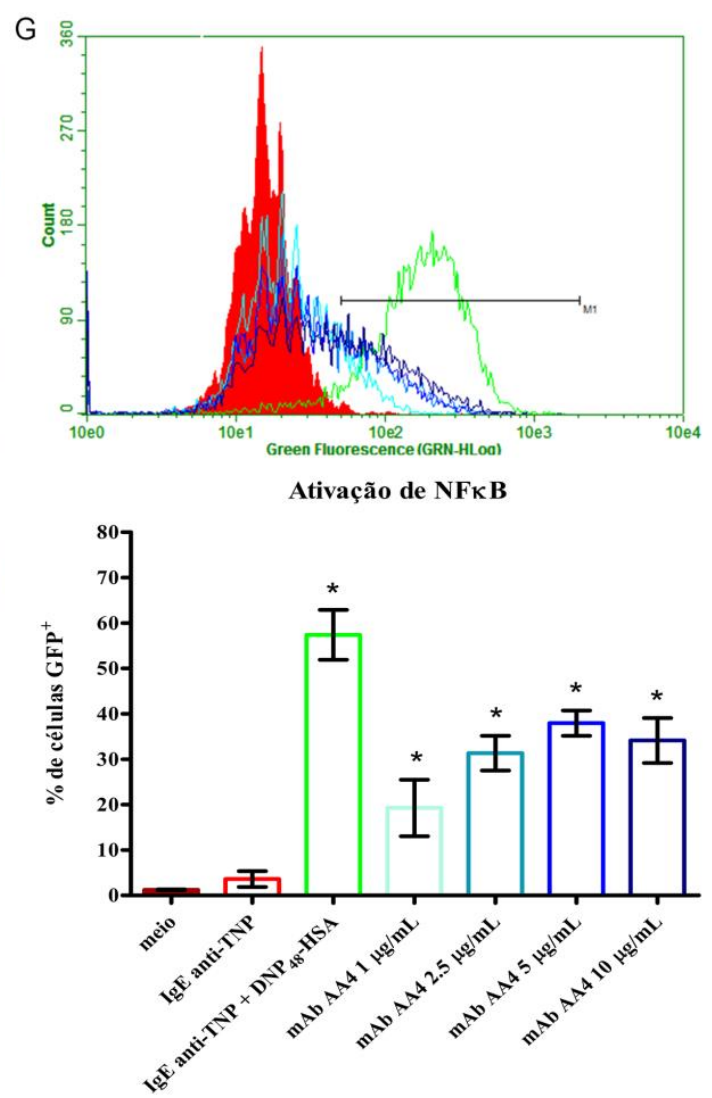

Figura 8. O intercruzamento dos gangliosídeos derivados do GD $1 \mathrm{~b}$ pela ligação ao

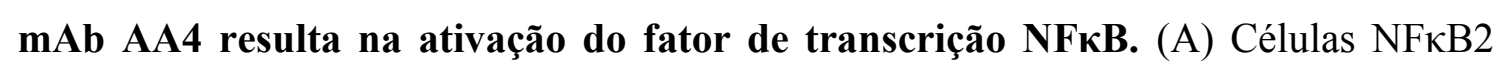
estimuladas com $5 \mu \mathrm{g} / \mathrm{mL}$ do mAb AA4 expressam GFP, microscopia de fluorescência; (B) Sobreposição do mesmo campo mostrado em A com DIC; (C) Células NFkB2 sensibilizadas com IgE anti-TNP e estimuladas com DNP48-HSA são GFP'; (D) Mesmo campo mostrado em C, observado com DIC; (E) Controle: células não estimuladas; (F) mesmo campo mostrado em E, observado com DIC; Barra: $10 \mu \mathrm{m}$; (G) Citometria de fluxo de células NFאB2 estimuladas ou não. $* P<0.0001$. Os dados representam a média \pm desvio padrão de 4 experimentos independentes. 
Porém, não ocorre ativação do fator de transcrição NFאB na linhagem IC2 (Sykº), após o intercruzamento dos gangliosídeos derivados do GD 1b pelo mAb AA4 (Figura 9).
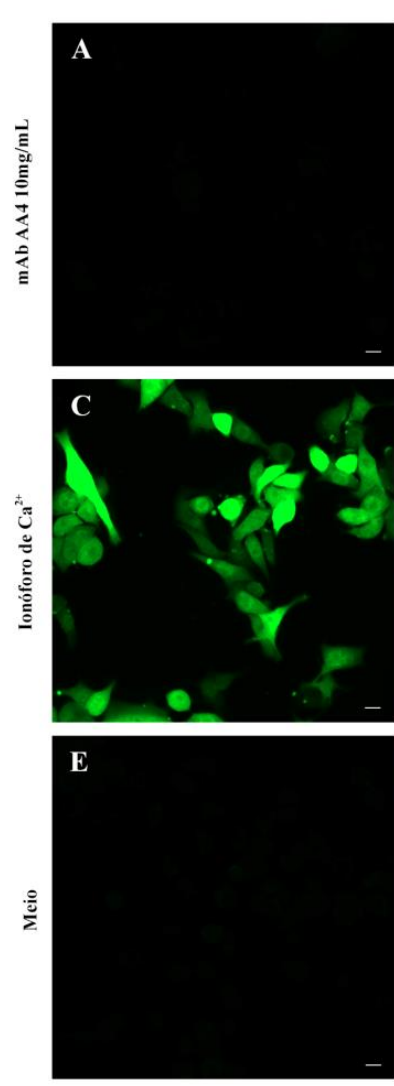
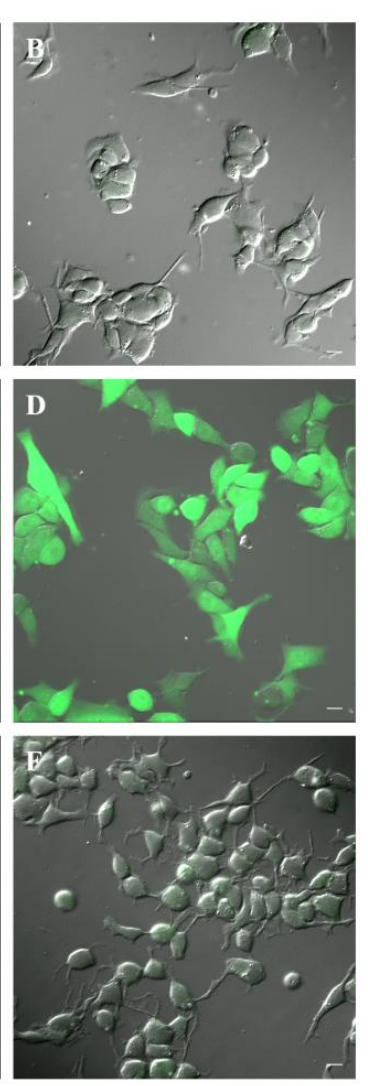
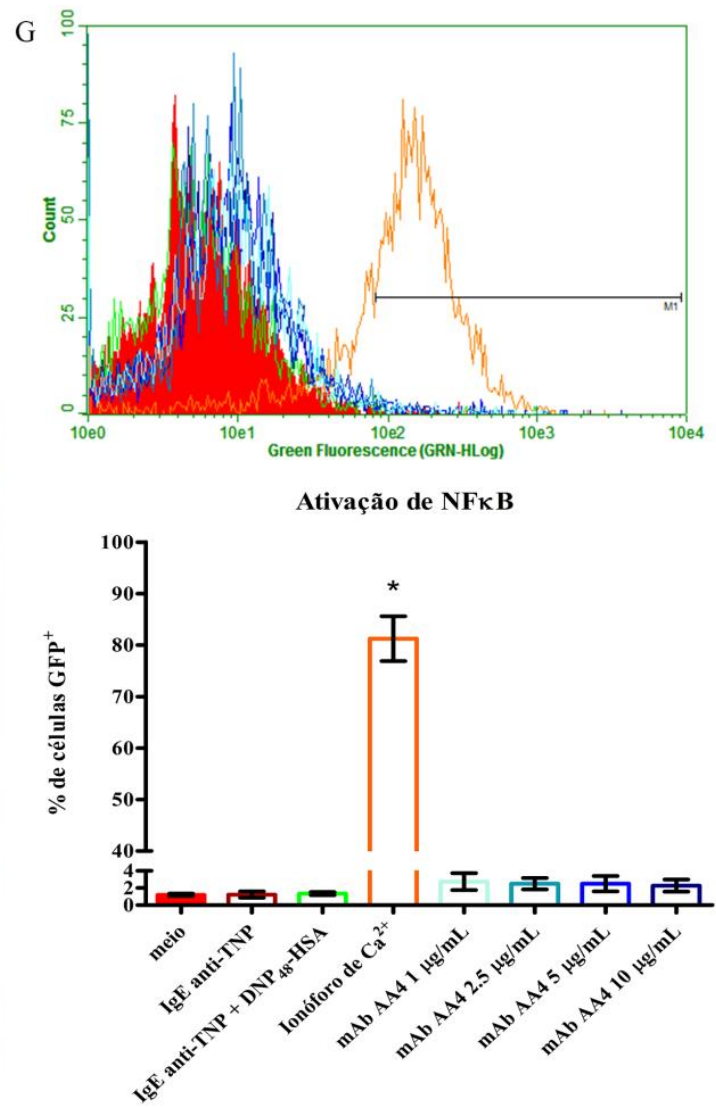

Figura 9. O intercruzamento dos gangliosídeos derivados do GD 1 bela ligação ao mAb AA4 é dependente da PTK Syk para ativação do fator de transcrição NFkB. (A) Células IC2 estimuladas com $10 \mu \mathrm{g} / \mathrm{mL}$ do mAb AA4 não expressão GFP, microscopia de fluorescência; (B) Sobreposição do mesmo campo mostrado em A com DIC; (C) Células IC2 estimuladas com ionóforo de cálcio são $\mathrm{GFP}^{+}$; (D) Mesmo campo mostrado em C, observado com DIC; (E) Controle: células não estimuladas; (F) mesmo campo mostrado em E, observado com DIC; Barra: $10 \mu \mathrm{m}$; (G) Citometria de fluxo de células IC2 estimuladas ou não. ${ }^{*} P<0.0001$. Os dados representam a média \pm desvio padrão de 4 experimentos independentes.

Os nossos resultados mostram que o intercruzamento dos gangliosídeos derivados

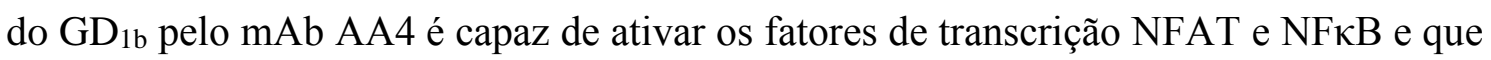
esta ativação é dependente de Syk. 


\section{O INTERCRUZAMENTO DOS GANGLIOSÍDEOS DERIVADOS DO GD PELO mAb AA4 RESULTA NA LIBERAÇÃO DE MEDIADORES NEO- SINTETIZADOS}

A produção por mastócitos de mediadores neo-sintetizados relacionados com a inflamação depende da ativação dos fatores de transcrição NFAT e NFkB (Gilfillan \& Tkaczyk, 2006). Nossos resultados mostram que o intercruzamento dos gangliosídeos derivados do $\mathrm{GD}_{1 \mathrm{~b}}$ pelo mAb AA4 ativam estes fatores de transcrição resultando na liberação dos mediadores neo-sintetizados.

Os mastócitos RBL-2H3 liberam IL-4 no sobrenadante após o intercruzados os gangliosídeos derivados do $\mathrm{GD}_{1 \mathrm{~b}}$. A liberação de IL-4 é dose dependente e atingiu 61 $\mathrm{pg} / \mathrm{mL}$ quando as células RBL-2H3 foram incubadas com $10 \mu \mathrm{g} / \mathrm{mL}$ do mAb AA4 por 24 horas. A liberação foi de $82 \mathrm{pg} / \mathrm{mL}$ quando as células RBL-2H3 foram ativadas via FceRI (controle positivo) (Figura 10). 


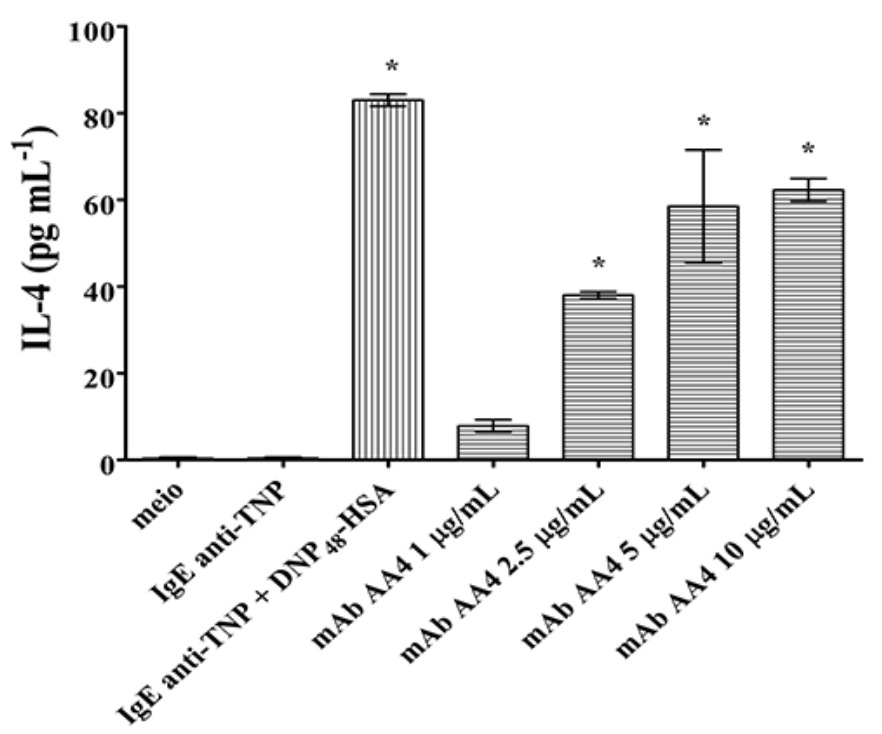

Figura 10. O intercruzamento dos gangliosídeos derivados do GD $1 \mathrm{~b}$ pelo mAb AA4 resulta na liberação de IL-4. Mastócitos RBL-2H3 incubados com o mAb AA4 (1; 2,5; 5 e $10 \mu \mathrm{g} / \mathrm{mL})$. $* P<0.0001$. Os dados representam a média \pm desvio padrão de 3 experimentos realizados em triplicata.

O intercruzamento dos gangliosídeos derivados do $\mathrm{GD}_{1 \mathrm{~b}}$ também promove a liberação de TNF- $\alpha$. Esta liberação é dose dependente e atinge $47 \mathrm{pg} / \mathrm{mL}$ quando as células RBL-2H3 são incubadas com $10 \mu \mathrm{g} / \mathrm{mL}$ do mAb AA4 por 24 horas, enquanto as células ativadas via FceRI (controle positivo) liberaram 65 pg/mL (Figura 11). 


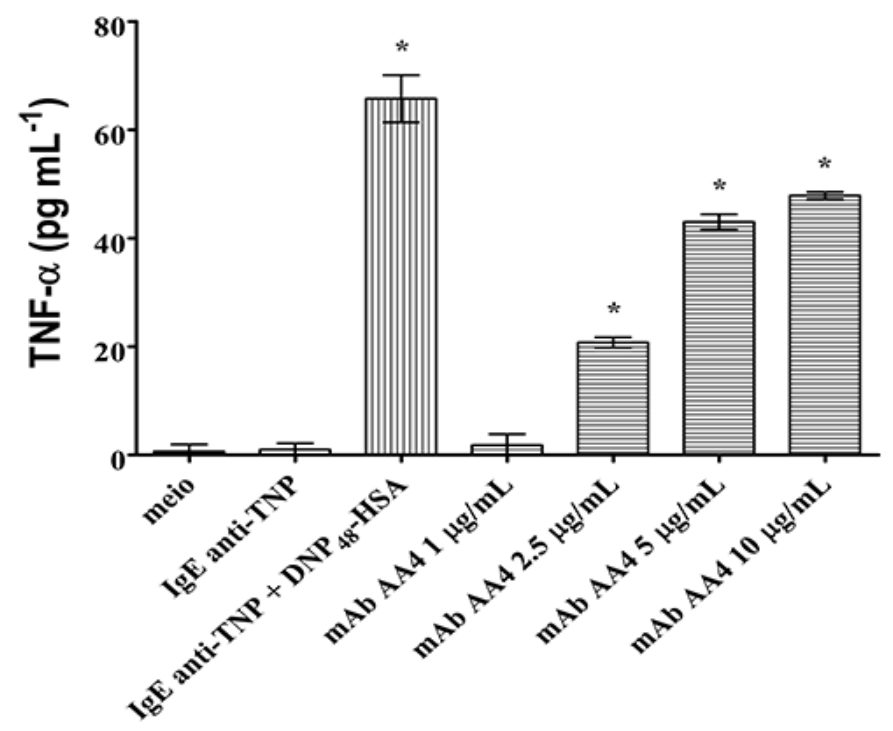

Figura 11. O intercruzamento dos gangliosídeos derivados do GD $1 \mathrm{~b}$ pelo mAb AA4 resulta na liberação de TNF- $\alpha$. Mastócitos RBL-2H3 incubados com o mAb AA4 (1; 2,5; 5 e $10 \mu \mathrm{g} / \mathrm{mL})$. $* P<0.0001$. Os dados representam a média \pm desvio padrão de 3 experimentos realizados em triplicata.

Os nossos resultados mostram que o intercruzamento dos gangliosídeos derivados do $\mathrm{GD}_{1 \mathrm{~b}}$ pelo mAb AA4 libera de forma dose dependente os mediadores neo-sintetizados IL-4 e TNF- $\alpha$.

\section{O INTERCRUZAMENTO DOS GANGLIOSÍDEOS DERIVADOS DO GD} PELO mAb AA4 NÃO RESULTA NA LIBERAÇÃO DE MEDIADORES NEOFORMADOS

A ativação dos mastócitos também resulta na produção de mediadores lipídicos dependentes da ativação da fosfolipase A2, classificados como mediadores neoformados. Os mediadores neoformados podem ser liberados sem que ocorra a desgranulação dos mastócitos (Grodzki et al, 2009). Assim sendo, a liberação de mediadores neoformados 
como o LTB4 e o LTC4 foram investigados após a agregação dos gangliosídeos derivados do GD1b pelo mAb AA4, em mastócitos RBL-2H3 e mastócitos C4A2 (Syk $\left.{ }^{-/}\right)$.

Os mastócitos RBL-2H3 e C4A2 não liberam LTB4 (Figura 12) e LTC4 (Figura 13) após a incubação com $5 \mu \mathrm{g} / \mathrm{mL}$ ou $10 \mu \mathrm{g} / \mathrm{mL}$ (dado não mostrado) de mAb AA4. Os mastócitos RBL-2H3 estimulados via FceRI e os mastócitos C4A2 (Syk) estimulados com ionóforo de cálcio (controles positivos) liberam LTB4 e LTC4.

$\mathbf{A}$

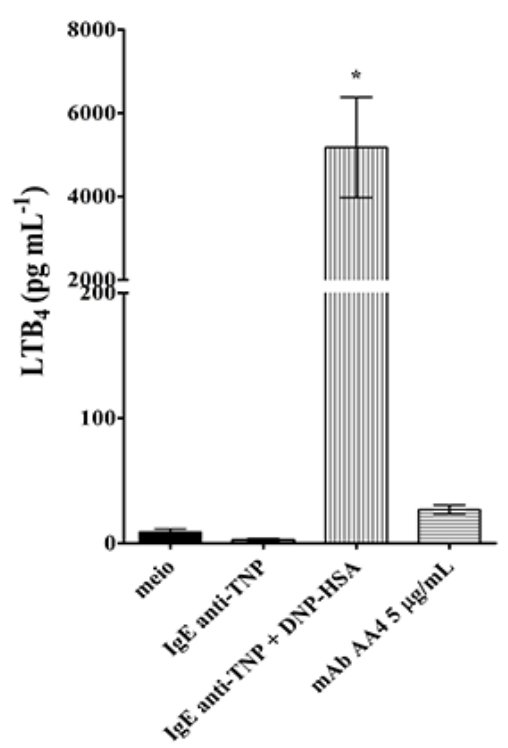

B

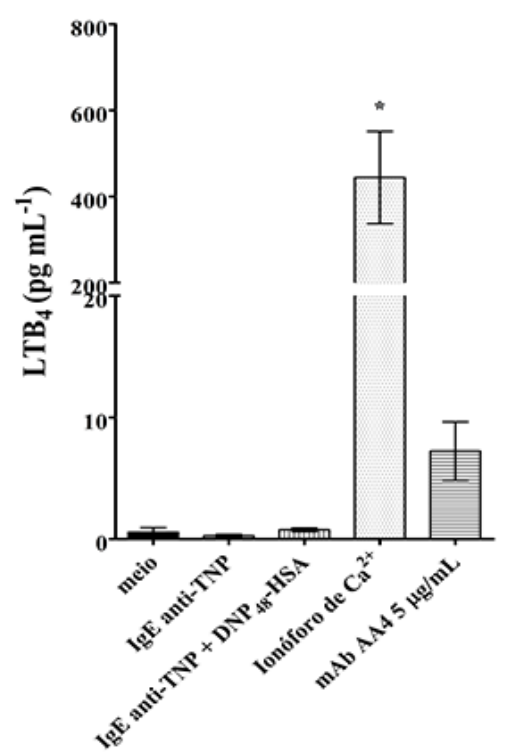

Figura 12. O intercruzamento dos gangliosídeos derivados do GD $1 \mathrm{~b}$ pelo mAb AA4 não resulta na liberação do mediador lipídico LTB4. Mastócitos RBL-2H3 (A) e mastócitos C4A2 (B) incubados com $5 \mu \mathrm{g} / \mathrm{mL}$ do mAb AA4 não liberam LTB4. $* P<0.0001$. Os dados representam a média \pm desvio padrão de 3 experimentos realizados em triplicata. 
$\mathbf{A}$

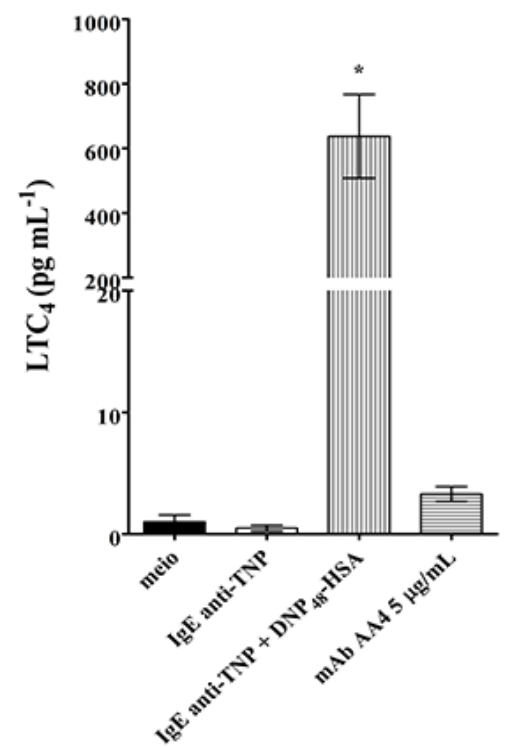

B

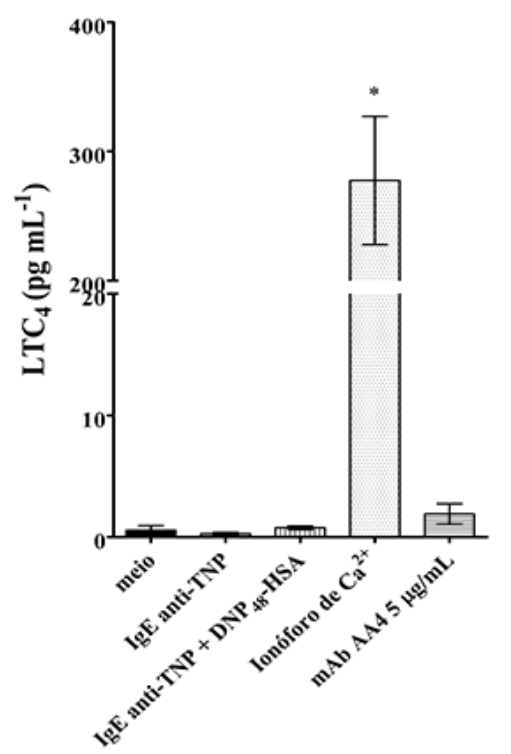

Figura 13. $O$ intercruzamento dos gangliosídeos derivados do GD ${ }_{1 b}$ pela ligação ao mAb AA4 não resulta na liberação do mediador lipídico LTC4. Mastócitos RBL-2H3 (A) e mastócitos C4A2 (B) incubados com $5 \mu \mathrm{g} / \mathrm{mL}$ do mAb AA4 não liberam LTC4. $* P<0.0001$. Os dados representam a média \pm desvio padrão de 3 experimentos realizados em triplicata.

Os nossos resultados mostram que o intercruzamento dos gangliosídeos derivados do GDıb pelo mAb AA4 não resulta na liberação dos mediadores lipídicos LTB4 e LTC4.

\section{A AGREGAÇÃO dOS GANGLIOSÍDEOS DERIVAdOS DO GD ${ }_{1 \mathrm{~b}}$ RESULTA NA DESORGANIZAÇÃO DOS LIPID RAFTS DE MASTÓCITOS RBL-2H3}

Os lipid rafts são plataformas lipídicas que promovem um microambiente na membrana plasmática, servindo de base para os complexos de sinalização. Nas células da linhagem de mastócitos RBL-2H3 não estimuladas o FcєRI está homogeneamente disperso na membrana plasmática. Imediatamente após a ativação dos mastócitos da linhagem RBL-2H3, via FceRI, os receptores e os componentes do complexo de sinalização são translocados para regiões de lipid rafts (Holowka \& Baird, 2001; Rivera 
et al, 2001; Stauffer \& Meyer, 1997; Wilson et al, 2000). As etapas iniciais da transdução de sinal em mastócitos ocorrem nestes microdomínios lipídicos (Wilson et al., 2002; Cebecauer et al, 2009; Holowka et al, 2005; Pizzo et al, 2004). Os gangliosídeos derivados do $\mathrm{GD}_{1 \mathrm{~b}}$ constituem um dos principais componentes dos lipid rafts de mastócitos RBL-2H3.

Diversos estudos mostram que o intercruzamento dos gangliosídeos derivados do $\mathrm{GD}_{1 \mathrm{~b}}$, pelo mAb AA4, promove uma ativação parcial dos mastócitos, mas não há desgranulação (Basciano et al, 1986; Oliver et al, 1992; Stephan et al, 1997; Swaim et al, 1994). Assim sendo, neste estudo foram analisados os lipid rafts de mastócitos RBL-2H3 após a agregação dos gangliosídeos derivados do GD 1 b. A distribuição do FceRI e de algumas proteínas envolvidas nas etapas iniciais da transdução de sinal foram investigadas nas frações de lipid rafts.

Quando os mastócitos da linhagem RBL-2H3 são incubados por 1 hora com o mAb AA4 e por mais 7 horas sem o anticopo, se observa uma desorganização dos lipid rafts. O FceRI está translocado para as frações de 2-7 (Figura 14A), ao invés de estar nas frações 2-3 de lipid rafts marcadas por LAT. A LAT, um marcador de lipid rafts em mastócitos RBL-2H3, está concentrada nas frações 2 e 3 (figura 14 e 15). Após a agregação pelo mAb AA4, os gangliosídeos derivados do GD 1 b, estão concentrados nas frações de 1-5, ao invés de estarem localizados nas frações de 2-7, como se observa em mastócitos RBL2H3 quando estes gangliosídeos não estão agregados (Figura 14B). Após a agregação dos gangliosídeos derivados do GD 1 b, a LAT também é translocada das frações 2 e 3 para as frações 1-5 (Figura 14C). 
A

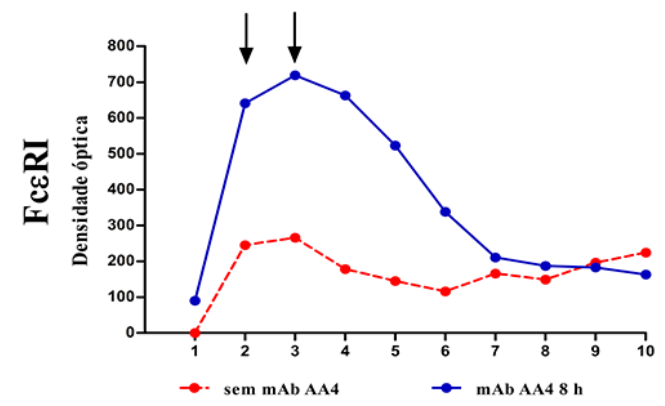

B

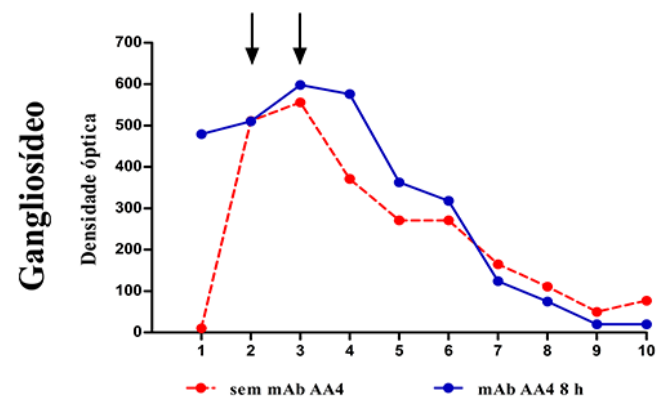

C

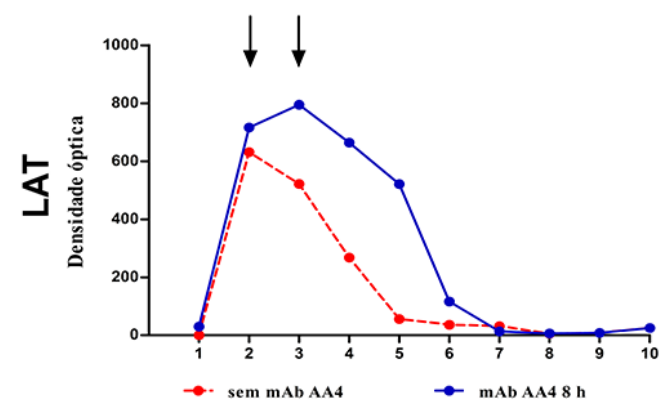

D

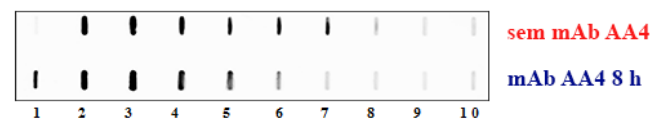

$\mathbf{E}$

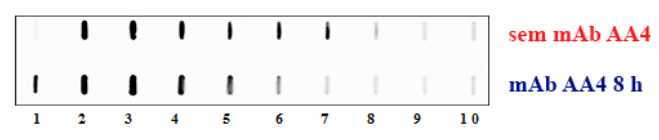

$\mathbf{F}$

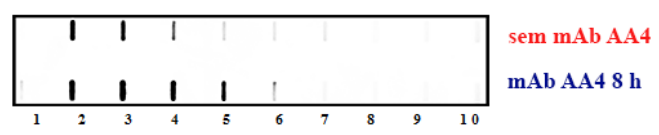

Figura 14. A formação de agregados dos gangliosídeos derivados do GD $\mathrm{D}_{1 \mathrm{~b}}$ pelo $\mathrm{mAb}$ AA4 promove a desorganização dos lipid rafts nos mastócitos RBL-2H3. O FceRI (A), os gangliosídeos derivados do $\mathrm{GD}_{1 \mathrm{~b}}$ (B) e a LAT (C) são mais recrutados para as frações de lipid rafts e redistribuídos nas frações não-rafts quando ocorre a formação de agregados de gangliosídeos pelo mAb AA4 na superfície celular; (D), (E) e (F) correspondem, respectivamente, aos Slot blots de A, B e C; Sem mAb AA4: mastócitos RBL-2H3 não incubados com mAb AA4; mAb AA4 8 h: mastócitos RBL-2H3 incubados por 1 hora com mAb AA4 e por mais 7 horas sem o anticorpo; Gradiente de Sacarose. Os dados são representativos de 6 experimentos. 
A análise do gradiente de sacarose mostra que após a agregação dos gangliosídeos derivados do $\mathrm{GD}_{1 \mathrm{~b}}$ a PTK Lyn está menos concentrada nas frações de lipid rafts 2-3, (Figura 15A). Também, a PTK Syk está menos concentrada nas frações de 2-6 em comparação com o observado quando os gangliosídeos não estão agregados (Figura 15B). A distribuição da Vav nas frações de lipid rafts foi similar entre mastócitos RBL-2H3 que tiveram ou não os gangliosídeos derivados do GD 1 bgregados (Figura 15C). 
$\mathbf{A}$

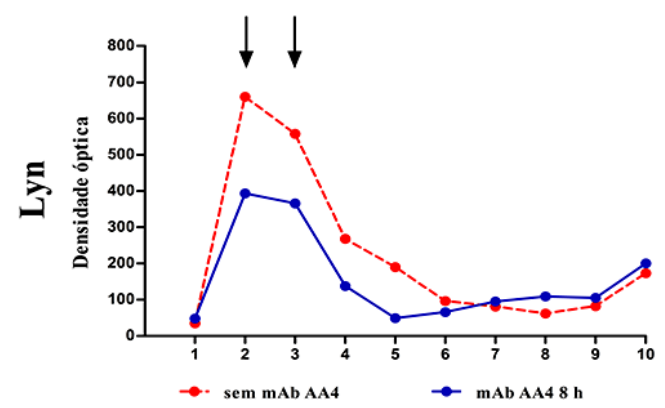

B

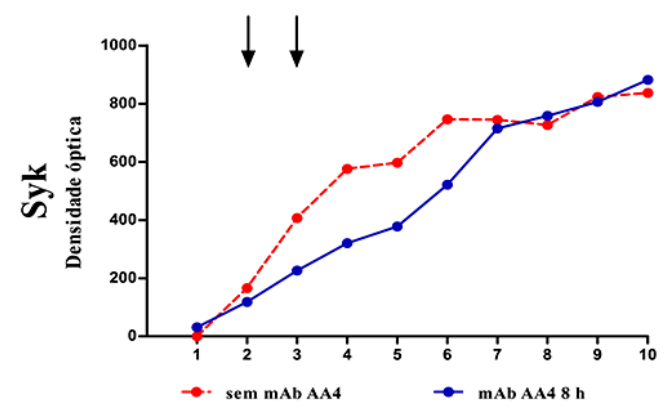

C

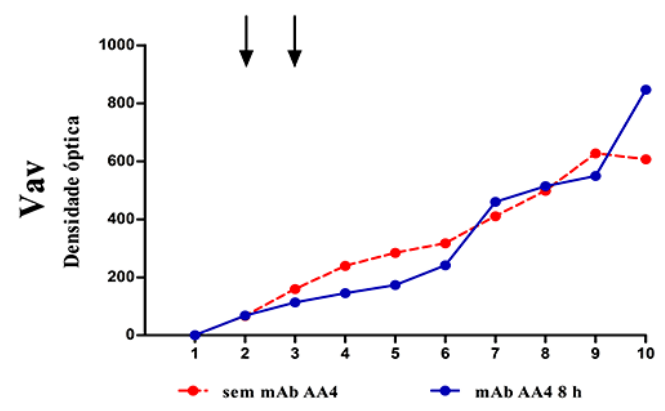

D

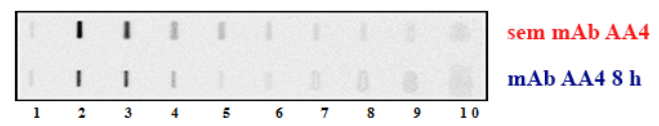

$\mathbf{E}$

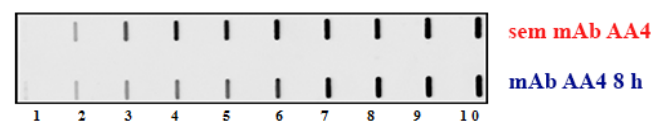

$\mathbf{F}$

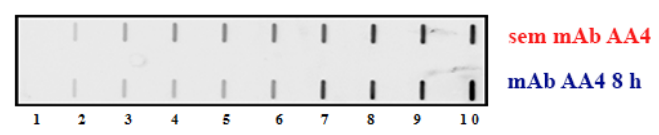

Figura 15. A formação de agregados dos gangliosídeos derivados do GD $\mathrm{D}_{1 \mathrm{~b}}$ pelo $\mathrm{mAb}$ AA4 promove a desorganização dos lipid rafts nos mastócitos RBL-2H3. A Lyn (A) e a Syk (B) apresentam redução nas frações de lipid rafts quando ocorre a formação de agregados de gangliosídeos pelo mAb AA4 na superfície celular. A Vav (C) não apresenta diferença notável quanto a sua distribuição nas frações do gradiente de sacarose entre as condições experimentais; (D), (E) e (F) correspondem, respectivamente, aos Slot blots de A, B e C; Sem mAb AA4: mastócitos RBL-2H3 não incubados com mAb AA4; mAb AA4 8 h: mastócitos RBL-2H3 incubados por 1 hora com mAb AA4 e por mais 7 horas sem o anticorpo; Gradiente de Sacarose._Os dados são representativos de 6 experimentos. 


\section{PROTEOMA COMPARATIVO DOS LIPID RAFTS DE MASTÓCITOS RBL- 2H3 COM OU SEM A AGREGAÇÃO DOS GANGLIOSÍDEOS DERIVADOS DO GD1b}

A agregação dos gangliosídeos derivados do GD 1 b resulta na desorganização dos lipid rafts os quais constituem plataformas para a sinalização dos mastócitos. Assim sendo, foi de interesse investigar as proteínas associadas aos lipid rafts quando os gangliosídeos estão agregados ou não, através de proteômica comparativa. O pool das frações de lipid rafts (2-3) foi submetido à eletroforese, para analisar a integridade das bandas correspondentes às proteínas presentes. Confirmada a integridade das amostras, o sequenciamento shotgun e a quantificação livre de marcação (LFQ) das proteínas reduzidas, alquiladas e digeridas por tripsina foram realizados. As amostras foram analisadas por NanoUPLC-MS ${ }^{\mathrm{E}}$, um método que permite a quantificação absoluta das proteínas obtidas nos dados de LC-MS/MS a partir de peptídeos trípticos oriundos de misturas complexas sem a necessidade do uso de inúmeros peptídeos externos de referência ou implementação de métodos radiomarcados.

Para minimizar a variação associada ao desempenho da coluna do HPLC e a eficiência da ionização, a mistura de peptídeos trípticos de cada uma das amostras foram analisadas sequencialmente sob condições idênticas de LC-MS/MS em espectrômetro de massa de alta resolução. Os espectros foram pesquisados no banco de dados de proteínas de rato (UNIPROT) e então rigorosamente filtrados pela exatidão de massas e scores correspondentes.

A pesquisa no banco de dados do Mascot identificou 486 proteínas associadas aos lipid rafts das células da linhagem de mastócitos de rato RBL-2H3 com um índice 2\% de falsa descoberta. Para uma análise global do proteoma de lipid rafts de mastócitos RBL2H3 sem nenhum tratamento, as proteínas foram primeiramente categorizadas de acordo 
com as 3 principais categorias do Gene Ontology (GO): componentes celulares; processos biológicos e função molecular. Os dados foram obtidos pelo Software Tool for Researching Annotations of Proteins (STRAP). Os resultados estão resumidos nos gráficos da figura 8.

As 486 proteínas apareceram 1.452 vezes quando classificadas dentro do grupo "componentes celulares", sendo $15 \%$ desta contagem relacionada com o termo "extracelular"; $12 \%$ com o termo "citoplasma" e $9 \%$ foi relacionada à "membrana plasmática" (Figura 16A). Com relação ao termo organelas intracelulares foram encontradas associação com "mitocôndria" 6,8\%, "núcleo" 12\%, "retículo endoplasmático" 3,6\% e "outras organelas" $8,1 \%$.

$\mathrm{Na}$ categoria "processos biológicos" os maiores grupos foram relacionados com "processos celulares" 26,2\%, "regulação"22,6\% e "resposta a estímulo" 9\%. (Figura 16B). Na categoria "função molecular", 48,4\% foi associada a "ligação" e 28,4\% a “atividade catalítica" (Figura 16C).
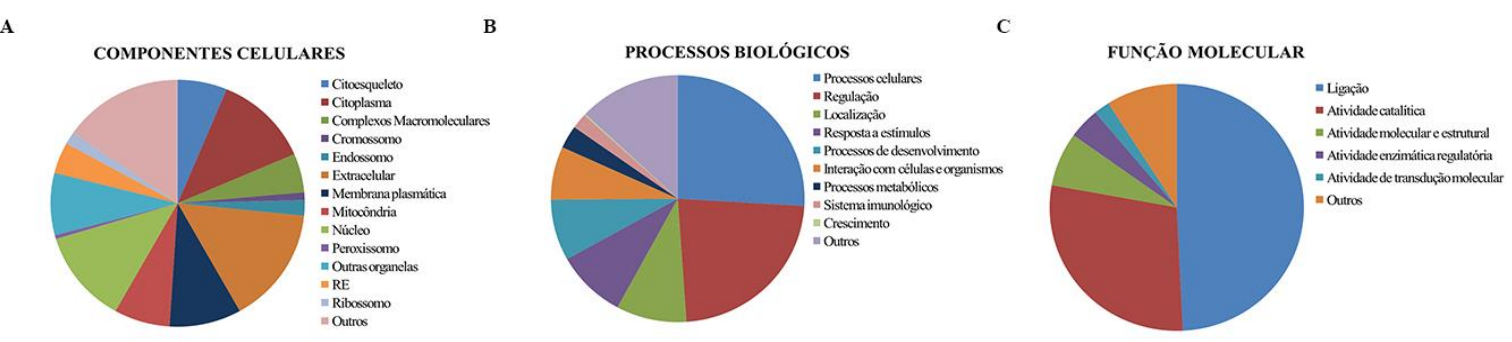

Figura 16. Dados associados aos termos do Gene Ontology (GO) referentes às 486 proteínas identificadas nos lipid rafts da linhagem de mastócitos de rato RBL-2H3 anotados pelo STRAP. As proteínas identificadas foram agrupadas de acordo com as 3 principais categorias do GO: (A) componentes celulares; (B) processos biológicos e (C) função molecular. As subcategorias estão indicadas na legenda e distribuídas de acordo com as cores.

Para o melhor entendimento do papel dos gangliosídeos derivados do $\mathrm{GD}_{1 \mathrm{~b}}$ na organização e funcionamento dos complexos de sinalização, as proteínas associadas aos 
lipid rafts, na presença ou não de agregados destes gangliosídeos, foram investigadas por proteômica comparativa. No extrato proteico obtido das frações de lipid rafts na presença de agregados dos gangliosídeos foram identificadas 475 proteínas e na ausência desses agregados foram identificadas 486 proteínas. Destas proteínas, 385 foram identificadas em ambos os extratos; 90 proteínas foram identificadas somente em lipid rafts de células com agregados de gangliosídeos e 101 proteínas foram identificadas em extratos de células que não tiveram os gangliosídeos agregados.

Os resultados obtidos pela NanoUPLC-MS ${ }^{\mathrm{E}}$ foram processados e analisados no Mascot v2.2. A razão entre as condições experimentais foi calculada para cada proteína identificada pelo software. A significância foi definida por fold change de no mínimo 1,5 na expressão das proteínas entre as duas condições, ou seja, up reguladas quando apresentado fold change de $1,5\left(\log _{2}\right.$ ratio de $\left.\geq 0,59\right)$ e down reguladas quando apresentado fold change de $-1,5\left(\log _{2}\right.$ ratio de $\left.\geq-0,59\right)$. Na tabela 1 estão listadas as proteínas identificadas por nossa análise de cromatografia líquida acoplada à espectrometria de massas e que são descritas como constituintes/associadas aos lipid rafts, bem como, envolvidas na cascata de transdução de sinal de mastócitos. As proteínas detectadas no extrato proteico das frações de lipid rafts de mastócitos com gangliosídeos derivados do $\mathrm{GD}_{1 \mathrm{~b}}$ agregados, quando em maior quantidade foram denominadas up reguladas e quando em quantidades menores foram denominadas down reguladas. 
Tabela 1. Proteínas detectadas por NanoUPLC-MS ${ }^{\mathrm{E}}$ nas frações de lipid rafts de mastócitos RBL-2H3 quando os gangliosídeos derivados do GD1b estão agregados

\begin{tabular}{|c|c|c|c|}
\hline \multicolumn{4}{|c|}{$\begin{array}{l}\text { PROTEÍNAS UP REGULADAS NA PRESENÇA DE AGREGADOS DE } \\
\text { GANGLIOSÍDEOS DERIVADOS DO GD1b }\end{array}$} \\
\hline $\begin{array}{l}\text { Número de } \\
\text { acesso }^{\text {a) }}\end{array}$ & Descrição da proteínab) & $\begin{array}{l}\text { Mascot } \\
\text { Score }\end{array}$ & $\begin{array}{l}\text { Fold } \\
\text { Change }\end{array}$ \\
\hline F1LWE2 & Allergin $1 *$ & 1128 & - \\
\hline P07150 & Annexin Al & 28648 & 2,1 \\
\hline E9PTF7 & Btk & 411 & - \\
\hline Q6AYK6 & Calcyclin-binding protein & 1038 & 3,8 \\
\hline Q4QQV2 & Docking protein $1 *$ & 799 & - \\
\hline P62630 & Elongation factor 1-alpha 1 & 16649 & 1,9 \\
\hline P05197 & Elongation factor 2 & 17558 & 1,8 \\
\hline D3ZIE4 & $F y b$ & 454 & - \\
\hline P11762 & Galectin-1 & 7991 & 1,5 \\
\hline P08699 & Galectin-3 & 637 & - \\
\hline A3RLA8 & Low affinity Fc gamma receptor IIB isoform 1 & 1010 & 2 \\
\hline P21708 & Mitogen-activated protein kinase 3 & 795 & 1,5 \\
\hline P54319 & Phospholipase A-2-activating protein & 300 & - \\
\hline M0R3J5 & Platelet endothelial cell adhesion molecule* & 240 & - \\
\hline R9PXR7 & Prostaglandin E synthase 3 & 1704 & 1,5 \\
\hline F1LS36 & Protein kinase $C$ beta type* & 82 & - \\
\hline P09215 & Protein kinase $C$ delta type* & 82 & - \\
\hline P47196 & $R A C$ alpha serine/threonine protein kinase* & 487 & - \\
\hline P63245 & $R A C K 1$ & 10611 & 4,5 \\
\hline Q64303 & Serine/threonine-protein kinase PAK 2 & 648 & - \\
\hline Q62829 & Serine/threonine-protein kinase PAK 3 & 282 & - \\
\hline Q920G0 & Src kinase associated phosphoprotein $2 *$ & 642 & - \\
\hline G3V9T9 & $\begin{array}{l}\text { Tyrosine-protein phosphatase non-receptor } \\
\text { type }\end{array}$ & 1414 & - \\
\hline P81718 & $\begin{array}{l}\text { Tyrosine-protein phosphatase non-receptor } \\
\text { type } 6\end{array}$ & 1506 & - \\
\hline P31000 & Vimentin & 1477 & 4,9 \\
\hline G3V8C3 & Vimentin isoform $C R A \_b$ & 1477 & 4,8 \\
\hline P85972 & Vinculin & 1156 & - \\
\hline \multicolumn{4}{|c|}{$\begin{array}{l}\text { PROTEÍNAS DOWN REGULADAS NA PRESENÇA DE AGREGADOS DE } \\
\text { GANGLIOSÍDEOS DERIVADOS DO GD1b }\end{array}$} \\
\hline $\begin{array}{l}\text { Número de } \\
\text { acesso }^{\text {a) }}\end{array}$ & Descrição da proteína ${ }^{b)}$ & $\begin{array}{l}\text { Mascot } \\
\text { Score }\end{array}$ & $\begin{array}{c}\text { Fold } \\
\text { Change }\end{array}$ \\
\hline Q4KM97 & B lymphoid kinase* & 502 & - \\
\hline P97829 & CD47 antigen* & 207 & - \\
\hline P10252 & CD48 antigen & 943 & 6,6 \\
\hline Q9Z1E1 & Flotillin $1 *$ & 487 & - \\
\hline D4ABT0 & Guanine nucleotide binding protein $G o$ & 2919 & - \\
\hline
\end{tabular}




\begin{tabular}{|c|c|c|c|}
\hline P08753 & $\begin{array}{l}\text { Guanine nucleotide-binding protein } G(k) \\
\text { subunit alpha }\end{array}$ & 1366 & 2,8 \\
\hline P63095 & $\begin{array}{l}\text { Guanine nucleotide-binding protein } G(s) \\
\text { subunit alpha isoforms short }\end{array}$ & 1301 & 2,8 \\
\hline P19627 & $\begin{array}{l}\text { Guanine nucleotide-binding protein } G(z) \\
\text { subunit alpha }\end{array}$ & 1912 & - \\
\hline G3V6P8 & $\begin{array}{l}\text { Guanine nucleotide-binding protein subunit } \\
\text { gamma }\end{array}$ & 1231 & - \\
\hline F1LR63 & Interleukin 1 receptor like 1 & 970 & - \\
\hline P70580 & $\begin{array}{l}\text { Membrane-associated progesterone receptor } \\
\text { component } 1\end{array}$ & 505 & - \\
\hline P67779 & Prohibitin & 4371 & 2,8 \\
\hline Q5XIH7 & Prohibitin-2 & 1214 & - \\
\hline Q62726 & Serine threonine protein kinase ICK* & 130 & - \\
\hline P20793 & Serine threonine protein kinase $M A K^{*}$ & 130 & - \\
\hline O70377 & Synaptosomal associated protein $23 *$ & 321 & 7,5 \\
\hline M0RCY1 & $T E C-21$ & 1013 & 6,8 \\
\hline P01830 & Thy-1 & 1348 & 6 \\
\hline P61589 & Transforming protein RhoA & 1383 & 2,7 \\
\hline Q62844 & Tyrosine protein kinase Fyn* & 140 & - \\
\hline FL1LP43 & Tyrosine protein kinase $H C K^{*}$ & 101 & - \\
\hline Q9WUD9 & tyrosine protein kinase Src* & 140 & - \\
\hline Q6AXQ3 & Tyrosine protein kinase Yes* & 150 & 5,2 \\
\hline Q6P6U0 & Tyrosine-protein kinase Fgr & 140 & - \\
\hline Q07014 & Tyrosine-protein kinase Lyn & 590 & 6,4 \\
\hline Q63116 & Tyrosine-protein kinase receptor & 274 & 2,2 \\
\hline P63025 & Vesicle-associated membrane protein 3 & 440 & - \\
\hline
\end{tabular}

\section{ANÁLISE DAS PROTEÍNAS UP REGULADAS NOS LIPID RAFTS QUANDO OS GANGLIOSÍDEOS DERIVADOS DO GD $1 \mathrm{~b}$ ESTÃO AGREGADOS}

A análise proteômica dos lipid rafts demonstra alteração na sua composição proteica quando os gangliosídeos derivados do $\mathrm{GD}_{1 \mathrm{~b}}$ estão agregados. Os resultados mostram que proteínas capazes de desencadear uma ativação parcial dos mastócitos e 
proteínas reguladoras negativas da desgranulação estão up reguladas, enquanto que proteínas críticas para a transdução do sinal estão down reguladas.

\subsection{Vimentina}

A análise proteômica mostra que a vimentina está up regulada (fold change 5) nos lipid rafts quando os gangliosídeos derivados do GD 1 b estão agregados. Nestas mesmas condições, a vimentina também está aumentada nas frações de lipid rafts (2-3) (Figura 17A). Quando estas frações são submetidas à Immunoblot e quantificadas, se observa um aumento de $23 \%$ de vimentina nas frações de lipid rafts de mastócitos RBL-2H3 que tiveram os gangliosídeos derivados do $\mathrm{GD}_{1 \mathrm{~b}}$ agregados (Figura 17C).

A

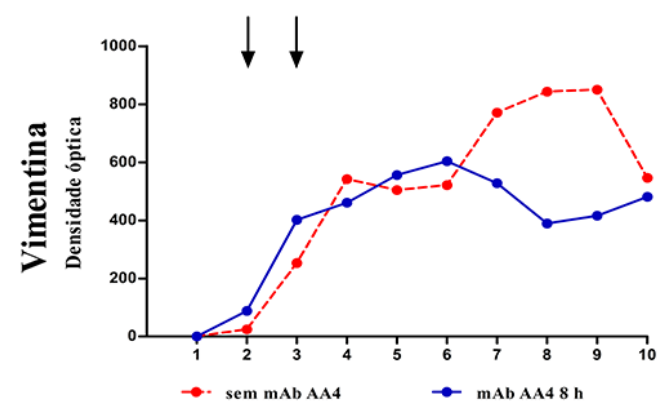

C

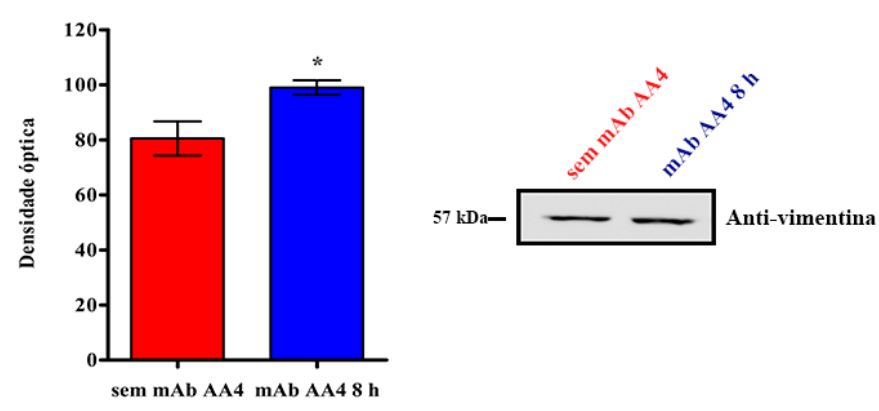

Figura 17. A vimentina está aumentada nas frações de lipid rafts quando os gangliosídeos derivados do GD 1 b estão agregados. (A) Distribuição de vimentina no gradiente de sacarose; (B) Slot Blot de A; (C) Quantificação do Immunoblot (D) das frações de lipid rafts (2-3) com o anticorpo anti-vimentina. Sem mAb AA4: mastócitos RBL-2H3 não incubados com mAb AA4; mAb AA4 8 h: mastócitos RBL-2H3 incubados por 1 hora com mAbAA4 e por mais 7 horas sem o anticorpo; $* P<0.0001$. Os dados representam a média \pm desvio padrão de 3 experimentos independentes. 
A distribuição da vimentina em relação aos agregados de gangliosídeos derivados do $\mathrm{GD}_{1 \mathrm{~b}}$ foi observada por imunofluorescência. Os resultados mostram que a vimentina está distribuída ao longo da membrana plasmática dos mastócitos RBL-2H3 que não foram incubadas com mAb AA4 (Figura 18).

RBL-2H3 - SEM mAb AA4
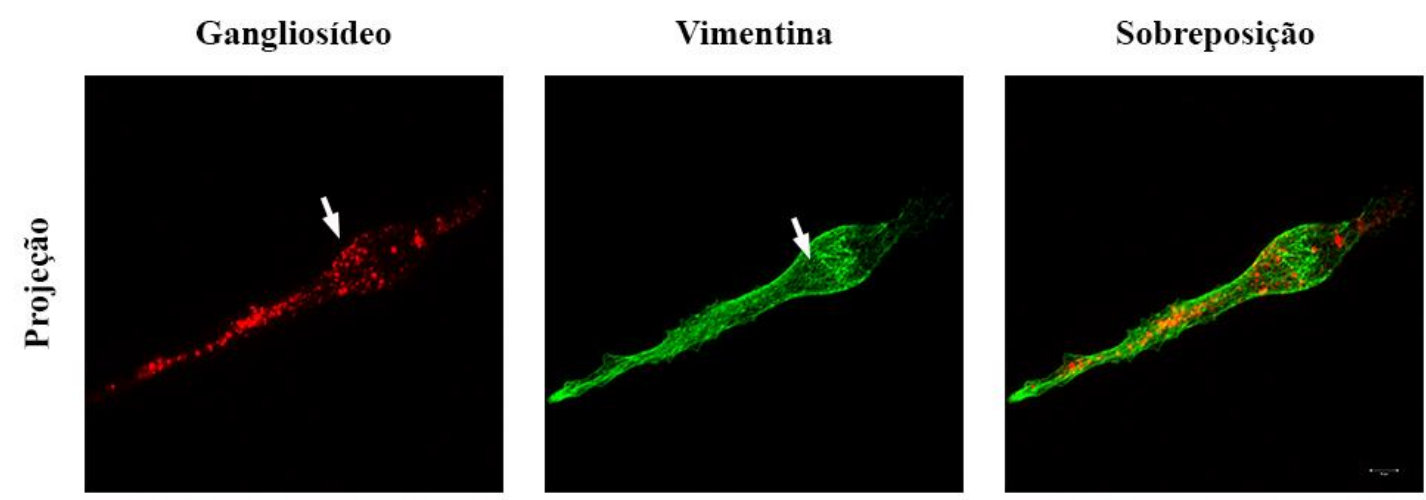

Figura 18. Distribuição de vimentina e dos gangliosídeos derivados do GD Gb $_{1 b}$ em mastócitos RBL-2H3. Os gangliosídeos estão distribuídos na superfície celular (seta); Os filamentos de vimentina estão distribuídos ao longo do maior eixo da célula e abaixo da membrana plasmática (seta); Sobreposição de gangliosídeos e vimentina; Sem mAb AA4: mastócitos RBL-2H3 não incubados com mAb AA4; Barra: $10 \mu \mathrm{m}$.

Na presença dos agregados de gangliosídeos derivados do GD 1 b a vimentina está concentrada nas regiões próximas a membrana plasmática de mastócitos RBL-2H3 estando mais associadas a estes gangliosídeos (Figura 19). Estes dados mostram que a agregação de gangliosídeos pelo mAb AA4 modifica a distribuição subcelular da vimentina. 
RBL-2H3 - mAb AA4 8 h
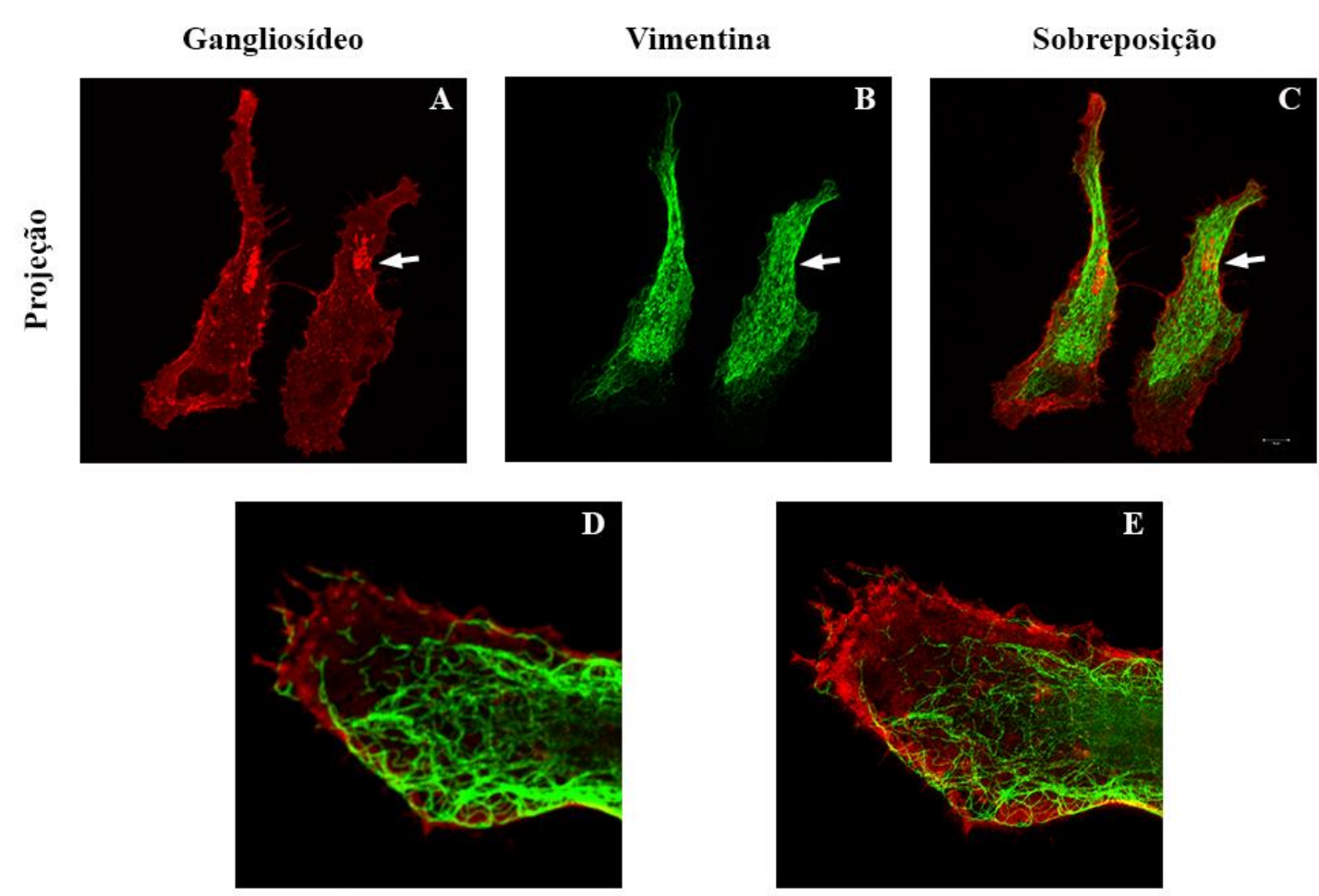

Figura 19. Distribuição de vimentina em mastócitos RBL-2H3 com gangliosídeos derivados do GD1b agregados. (A) Agregados de gangliosídeos na superfície celular (seta); (B) Filamentos de vimentina (seta); (C) A vimentina (verde) está distribuída abaixo da membrana plasmática próxima aos agregados de gangliosídeos derivados do $\mathrm{GD}_{1 \mathrm{~b}}$ (seta); (D) Filamentos de vimentina (verde) concentrados próximos ao agregado de gangliosídeos derivados do GD $1 \mathrm{~b}$ (vermelho), Confocal; (E) Detalhe dos filamentos de vimentina (verde) associados ao agregado de gangliosídeos derivados do GD $_{1 \mathrm{~b}}$ (STED Super-Resolution); mAb AA4 8 h: mastócitos RBL-2H3 incubados por 1 hora com mAb AA4 e por mais 7 horas sem o anticorpo; Barra: $10 \mu \mathrm{m}$.

\subsection{RACK1}

A análise proteômica mostra que a RACK1 (Receptor for Activated C Kinase) está up regulada (fold change 4,5) nas frações de lipid rafts quando os gangliosídeos derivados do GD 1 b estão agregados. Nestas mesmas condições, a RACK1 também está aumentada nas frações de lipid rafts (2-3) e nas frações não rafts (4-7) (Figura 20A). Quando estas frações são submetidas à Immunoblot e quantificadas, observa-se um aumento de 54\% 
nos níveis de RACK1 nas frações de lipid rafts quando os agregados de gangliosídeos derivados do $\mathrm{GD}_{1 \mathrm{~b}}$ estão presentes (Figura 20C).

A

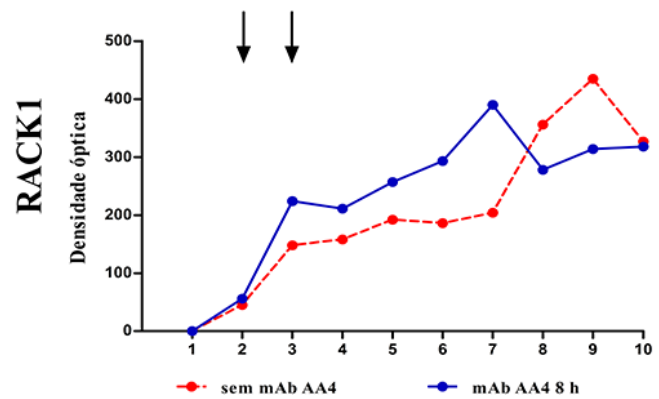

$\mathrm{C}$

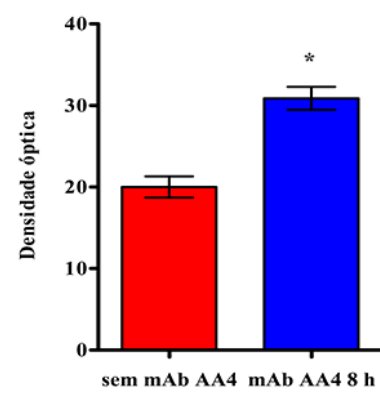

B

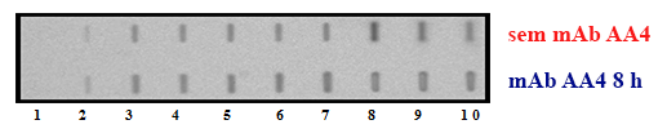

D

Figura 20. A RACK1 está aumentada nas frações de lipid rafts quando os gangliosídeos derivados do GD1b estão agregados. (A) Distribuição de RACK1 no gradiente de sacarose; (B) Slot Blot de A; (C) Quantificação do Immunoblot (D) das frações de lipid rafts (2-3) com o anticorpo anti-RACK1. Sem mAb AA4: mastócitos RBL-2H3 não incubados com mAb AA4; mAb AA4 8 h: mastócitos RBL-2H3 incubados por 1 hora com mAbAA4 e por mais 7 horas sem o anticorpo; $* P<0.0001$. Os dados representam a média \pm desvio padrão de 3 experimentos independentes.

\subsection{FC $\gamma$ RII}

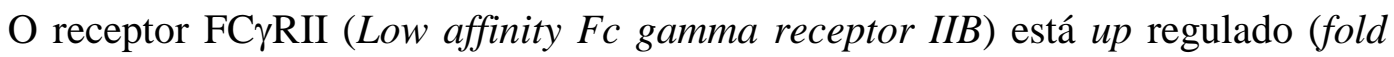
change 2) nas frações de lipid rafts quando os gangliosídeos derivados do $\mathrm{GD}_{1 \mathrm{~b}}$ estão agregados. Nestas mesmas condições, o FC $\gamma$ RII também está aumentado nas frações de lipid rafts (2-3) e nas frações não rafts (4-7) (Figura 21A). Quando estas frações são 
submetidas à Immunoblot e quantificadas, identificarmos o FC $\gamma \mathrm{RII}$ apenas nas frações de lipid rafts quando presentes os agregados dos gangliosídeos derivados do GD $1 \mathrm{~b}$ (Figura 21C).

A

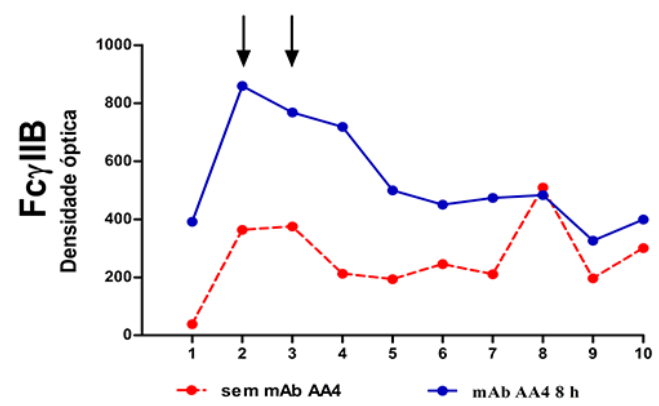

C

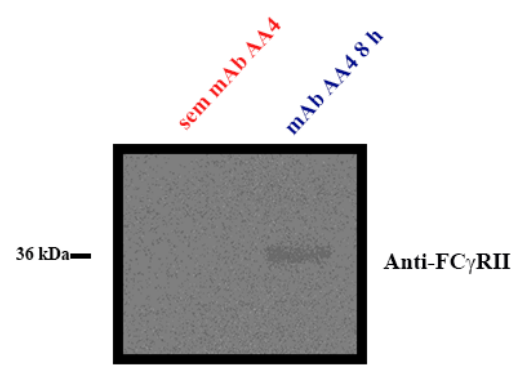

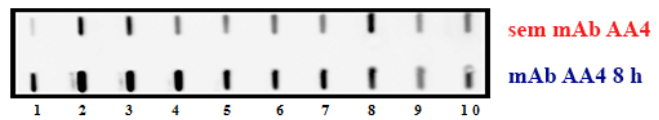

Figura 21. O FCyRII está aumentado nas frações de lipid rafts quando os gangliosídeos derivados do GD1b estão agregados. (A) Distribuição de FC $\gamma$ RII no gradiente de sacarose; (B) Slot Blot de A; (C) Immunoblot das frações de lipid rafts (2-3) com o anticorpo anti- FC $\gamma$ RII. Sem mAb AA4: mastócitos RBL-2H3 não incubados com mAb AA4; mAb AA4 8 h: mastócitos RBL-2H3 incubados por 1 hora com mAbAA4 e por mais 7 horas sem o anticorpo; Os dados representam 3 experimentos independentes.

\subsection{TEC-21}

A glicoproteína TEC-21 está ancorada a membrana plasmática por GPI. Esta proteína é altamente $N$-glicosilada e expressa na superfície de mastócitos de rato da linhagem RBL-2H3 (Dráber \& Dráberová, 2002). Na análise proteômica, a TEC-21 (fold change 6,8) está entre as proteínas down reguladas (tabela 1). Entretanto, ocorre um aumento da TEC-21 nas frações de lipid rafts (2-3) (Figura 22A) quando os gangliosídeos derivados do GD 1 b estão agregados. A quantificação do Immunoblot das frações de lipid 
rafts mostra que a TEC-21 aumenta 93\% nestas frações quando os gangliosídeos derivados do GD 1 b estão agregados (Figura 22C).

A

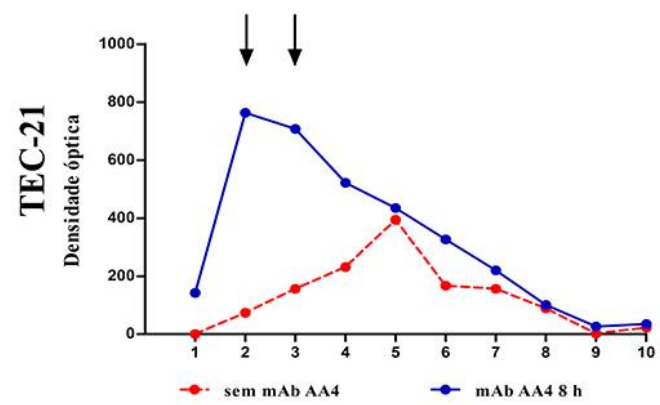

C

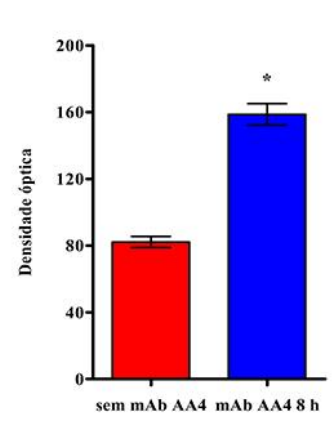

D

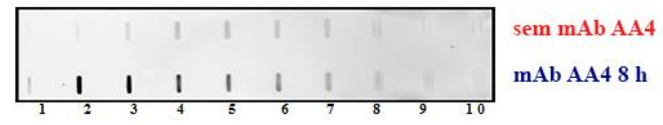

Figura 22. A TEC-21 está aumentada nas frações de lipid rafts quando os gangliosídeos derivados do GD1b estão agregados. (A) Distribuição de TEC-21 no gradiente de sacarose; (B) Slot blot de A; (C) Quantificação do Immunoblot (D) das frações de lipid rafts (2-3) com o anticorpo anti-TEC-21; As amostras não foram tratadas com enzimas glicolíticas, o que resulta em bandas adicionais no Immunoblot para TEC21. Sem mAb AA4: mastócitos RBL-2H3 não incubados com mAb AA4; mAb AA4 8 h: mastócitos RBL-2H3 incubados por 1 hora com mAbAA4 e por mais 7 horas sem o anticorpo; $* P<0.0001$. Os dados representam a média \pm desvio padrão de 3 experimentos independentes.

\subsection{Thy1}

Resultados semelhantes ao da TEC-21também foram observados para a glicoproteína Thy1. A Thy1 é altamente expressa em mastócitos de rato, especialmente em mastócitos da linhagem RBL-2H3 (Dráberová, 1989; Gunter et al, 1984). Na análise 
proteômica, a Thy1 (fold change 6) está entre as proteínas down-reguladas (tabela 1). Entretanto, ocorre um aumento da Thy1 nas frações de lipid rafts (2-3) (Figura 23A) quando os gangliosídeos derivados do $\mathrm{GD}_{1 \mathrm{~b}}$ estão agregados. A quantificação do Immunoblot das frações de lipid rafts mostra que a Thy1 aumenta 107\% nestas frações quando os gangliosídeos derivados do GD 1 b estão agregados (Figura 23C).

A
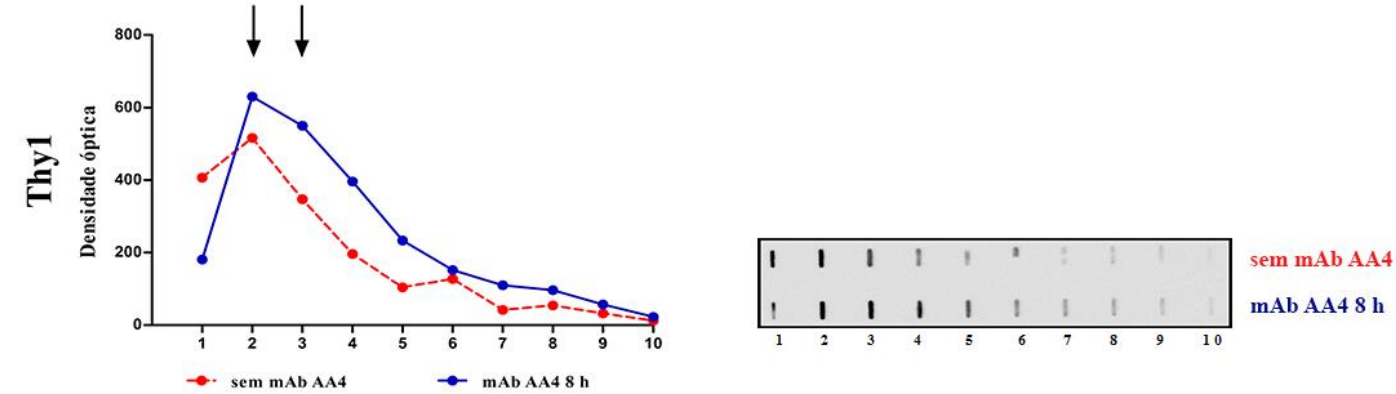

C

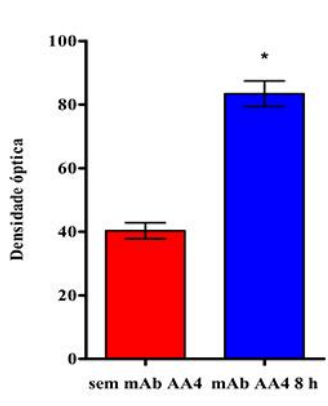

D

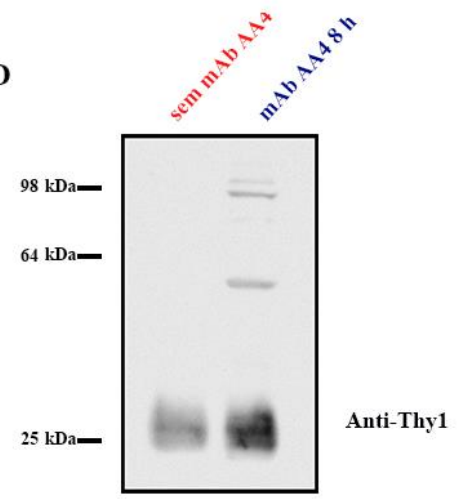

Figura 23. A Thy1 está aumentada nas frações de lipid rafts quando os gangliosídeos derivados do GD 1 bstão agregados. (A) Distribuição de Thy1 no gradiente de sacarose; (B) Slot Blot de A; (C) Quantificação do Immunoblot (D) das frações de lipid rafts (2-3) com o anticorpo anti-Thy1. Com gangliosídeos agregados observa-se bandas de 25-98 kDa. Sem mAb AA4: mastócitos RBL-2H3 não incubados com mAb AA4; mAb AA4 8 h: mastócitos RBL-2H3 incubados por 1hora com mAbAA4 e por mais 7 horas sem o anticorpo; $* P<0.0001$. Os dados representam a média \pm desvio padrão de 3 experimentos independentes. 


\section{ANÁliSE DAS PROTEÍNAS DOWN REGULADAS NOS LIPID RAFTS QUANDO OS GANGLIOSÍDEOS DERIVADOS DO GD Gb $_{1 \mathrm{~b}}$ ESTO AGREGADOS}

\subsection{Lyn}

A fosforilação do FceRI depende da proteína Lyn também encontrada nos lipid rafts. Os dados proteômicos mostram a Lyn no grupo de proteínas down reguladas (fold change 6,4) nas frações de lipid rafts quando os gangliosídeos derivados do $\mathrm{GD}_{1 \mathrm{~b}}$ estão agregados. Após a agregação dos gangliosídeos derivados do GD $\mathrm{Gb}_{1 \mathrm{~b}}$ a Lyn está reduzida nas frações de lipid rafts (2-3) (Figura 15A). A quantificação do Immunoblot das frações de lipid rafts também mostra uma redução de $28 \%$ de Lyn nas frações de lipid rafts quando os gangliosídeos derivados do GD 1 b estão agregados (Figura 24).

$\mathbf{A}$

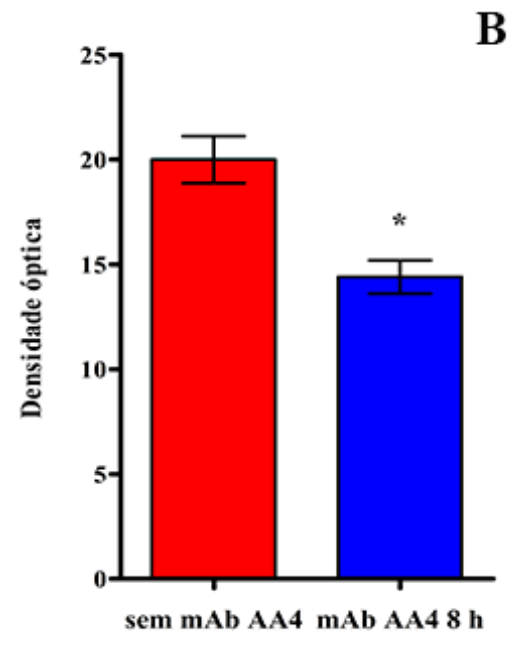

B

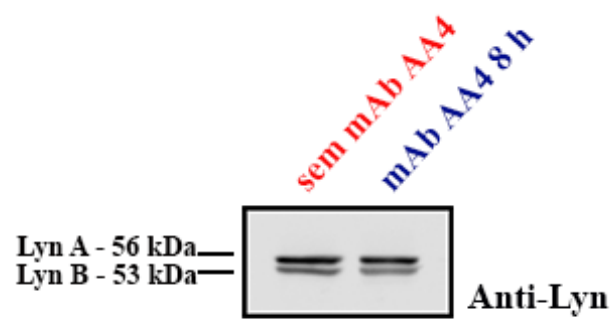

Figura 24. A Lyn está reduzida nas frações de lipid rafts quando os gangliosídeos derivados do GD1b estão agregados. (A) Quantificação do Immunoblot (B) das frações de lipid rafts (2-3) com o anticorpo anti-Lyn; Sem mAb AA4: mastócitos RBL-2H3 não incubados com mAb AA4; mAb AA4 8 h: mastócitos RBL-2H3 incubados por 1 hora com mAbAA4 e por mais 7 horas sem o anticorpo; $* P<0.0001$. Os dados representam a média \pm desvio padrão de 3 experimentos independentes. 
A Lyn se localiza na membrana plasmática dos mastócitos da linhagem RBL-2H3 (Kovárová et al., 2001). Os resultados de imunofluorescência mostram a Lyn na superfície celular e também no citoplasma mastócitos RBL-2H3 (Figura 25).

\section{RBL-2H3 - SEM mAb AA4}
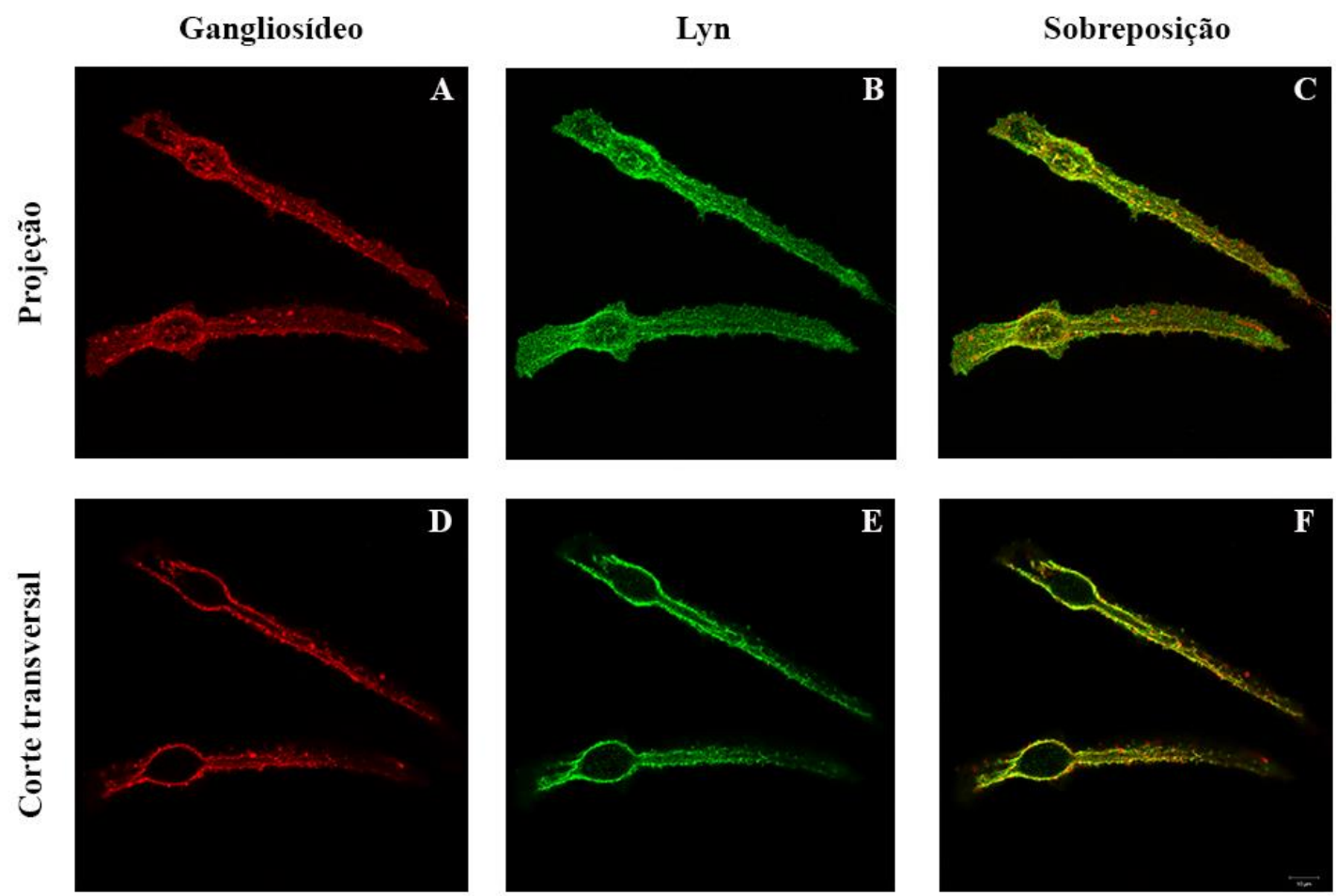

\section{Figura 25. Distribuição de Lyn e dos gangliosídeos derivados do GD $1 \mathrm{~b}$ em mastócitos}

RBL-2H3. (A) Os gangliosídeos estão distribuídos homogeneamente na superfície celular; (B) A Lyn está na membrana plasmática e no citoplasma; (C) Sobreposição de A e B; (D, E e F) Imagens com cortes transversais das imagens A, B e C, respectivamente; Sem mAb AA4: mastócitos RBL-2H3 não incubados com mAb AA4.

Nos mastócitos RBL-2H3 incubados com mAb AA4 por 1 hora e sem anticorpo por mais 7 horas, se observa uma baixa co-localização da Lyn com os agregados de gangliosídeos (Figura 26). Estes dados mostram que a agregação de gangliosídeos pelo mAb AA4 interfere na distribuição da PTK Lyn. 
RBL-2H3 - mAb AA4 8 h
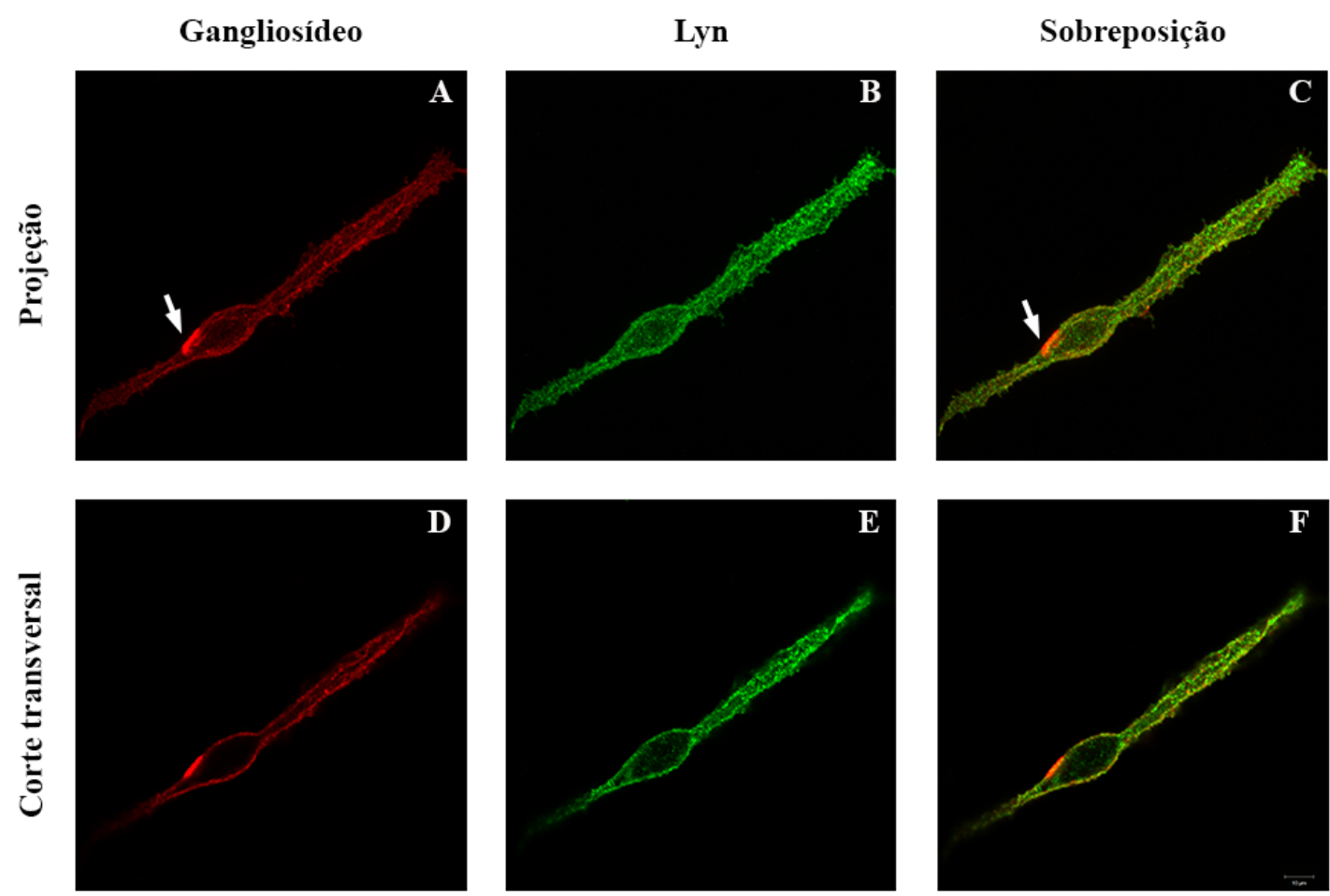

Figura 26. Distribuição de Lyn em mastócitos RBL-2H3 com gangliosídeos derivados do GD1b agregados. (A) Agregado de gangliosídeos (seta) na superfície celular; (B) A Lyn está distribuída na membrana plasmática e no citoplasma; (C) Sobreposição de A e B mostra que o agregado de gangliosídeos (seta) pouco se colocaliza com Lyn; (D, E e F) Cortes transversais das imagens A, B e C, respectivamente; mAb AA4 8 h: mastócitos RBL-2H3 incubados por 1 hora com mAb AA4 e por mais 7 horas sem anticorpo. 
DISCUSSÃO 


\section{DISCUSSÃO}

O presente estudo investiga o papel dos gangliosídeos derivados do $\mathrm{GD}_{1 \mathrm{~b}}$ na via de sinalização e liberação de mediadores de mastócitos.

A incubação dos mastócitos da linhagem RBL-2H3 com mAb AA4, que intercruza os gangliosídeos derivados de $\mathrm{GD}_{1 \mathrm{~b}}$, promove uma ativação parcial dos mastócitos, semelhante às observadas pela ativação via FcદRI, mas não resulta na desgranulação (Basciano et al, 1986; Oliver et al, 1992; Stephan et al, 1997; Swaim et al, 1994). Após 1 hora de incubação com mAb AA4 os gangliosídeos derivados do $\mathrm{GD}_{1 \mathrm{~b}}$ ainda estão dispersos na superfície de mastócitos RBL-2H3, porém após 1 hora de incubação com mAb AA4 e mais 7 horas sem o anticorpo os gangliosídeos formam agregados (caps) na superfície celular. Quando os mastócitos são estimulados via FceRI na presença do mAb AA4 a liberação de histamina e $\beta$-hexosaminidase são diminuídas de modo dose e tempo dependentes, estando inibida com 8 horas de pré-incubação com mAb AA4 (Basciano et al, 1986; Oliver et al, 2007). Os gangliosídeos derivados do $\mathrm{GD}_{1 \mathrm{~b}}$ podem então, exercer um papel na modulação da via de sinalização e subsequente liberação dos mediadores dos mastócitos (Guo et al, 1989; Silveira e Souza et al, 2008; Silveira e Souza et al, 2010).

No presente trabalho observamos que o intercruzamento dos gangliosídeos derivados do $\mathrm{GD}_{1 b}$ pelo mAb AA4 resulta na ativação dos fatores de transcrição NFAT (Nuclear factor of activated T-cells) e NFאB (Nuclear factor kB). Esta ativação é menor em relação à mediada por FcદRI (Grodzki et al, 2009). O NFAT e o NFkB uma vez ativados podem ser translocados para o núcleo e se ligarem a regiões regulatórias de genes envolvidos na produção de citocinas relacionadas à inflamação, resultando na expressão e liberação destas citocinas (Gilfillan \& Tkaczyk, 2006; Monticelli et al, 2004; Okamura et al, 2000). 
Em mastócitos estimulados via FcєRI, o NFAT é ativado quando desfosforilado pela calcineurina, uma serina treonina fosfatase dependente de $\mathrm{Ca}^{2+} /$ calmodulina (aumento de cálcio intracelular) (Gwack et al, 2007; Klein et al, 2006). Já para a ativação do NFкB é necessário o recrutamento e ativação de $\mathrm{PKC} \beta$ e PKC $\alpha$ (Su et al, 2002). O aumento intracelular de cálcio e o recrutamento de PKC foram observados por Oliver e colaboradores (1994) quando intercruzados os gangliosídeos derivados do GD 1 b. Nossos resultados também mostraram que a ativação dos fatores de transcrição NFAT e o NFkB resultante do intercruzamento dos gangliosídeos derivados do $\mathrm{GD}_{1 \mathrm{~b}}$ pelo mAb AA4 é mediada por PTK Syk. Syk estava diminuída nas frações de lipid rafts quando os gangliosídeos derivados do $\mathrm{GD}_{1 \mathrm{~b}}$ estão agregados, o que poderia explicar a menor ativação destes fatores de transcrição em relação à ativação mediada por FceRI. Dados da literatura mostram que Syk é essencial para a ativação dos fatores de transcrição mediada por receptor FceRI em mastócitos (Grodzki et al, 2009).

A ativação dos fatores de transcrição NFAT e NFkB é necessária para que ocorra a produção dos mediadores neo-sintetizados pelos mastócitos (Gilfillan \& Tkaczyk, 2006). Nossos resultados mostram que o intercruzamento dos gangliosídeos derivados do GD $1 \mathrm{~b}$ pelo mAb AA4 ativam estes fatores de transcrição e assim induz a liberação dos mediadores neo-sintetizados IL-4 e TNF- $\alpha$. Esta liberação é menor em relação à mediada por FceRI. Os mastócitos podem liberar uma gama diferente de mediadores dependendo das condições especiais de estímulo (Gonzalez-Espinosa et al, 2003). A IL-4 juntamente com outras citocinas como, IL-6, VEGF, IL-13 e TNF- $\alpha$ apresentam papel importante no processo inflamatório alérgico, induzindo uma mudança para o padrão de resposta Th2, levando a produção de IgE pelas células B (He et al, 2013; Hu Zhao \& Shimamura, 2007). Dados da literatura mostram a importância do TNF- $\alpha$ como um quimioatraente para neutrófilos e células T durante processos inflamatórios (Gordon \& Galli, 1990; 
Lauterbach et al, 2008). O TNF- $\alpha$ liberado pelo intercruzamento dos gangliosídeos derivados do $\mathrm{GD}_{1 \mathrm{~b}}$ é dependente da ativação dos fatores de transcrição, sendo portanto, um fator neo-sintetizado. Também existe TNF- $\alpha$ entre os mediadores pré-formados, armazenado nos grânulos de mastocitos, mas o intercruzamento dos gangliosídeos derivados do $\mathrm{GD}_{1 \mathrm{~b}}$ pelo mAb AA4 não resulta na desgranulação desta células (Oliver et al, 1992). A liberação dos mediadores neo-sintetizados não foi avaliada nos mastócitos $\mathrm{Syk}^{-/-}$, pois o intercruzamento dos gangliosídeos derivados do GD $1 \mathrm{~b}$ não foi capaz de ativar o fator de transcrição NFAT e NFkB na ausência de Syk.

Estes resultados mostram que a ativação de mastócitos através de gangliosídeos, embora não ocorra desgranulação, pode resultar na ativação dos fatores de transcrição NFAT e o NFkB e subsequente produção de mediadores neo-sintetizados. Por outro lado, o intercruzamento dos gangliosídeos derivados do $\mathrm{GD}_{1 \mathrm{~b}}$, pelo mAb AA4 não induz a liberação dos mediadores lipídicos LTB4 e LTC4. Embora, algumas pesquisas mostrem que os mediadores neoformados podem ser liberados sem que ocorra a desgranulação dos mastócitos (Grodzki et al, 2009).

Nossos resultados mostraram que após a formação dos agregados dos gangliosídeos derivados do $\mathrm{GD}_{1 \mathrm{~b}}$ através da incubação por 1 hora com mAb AA4 e por mais 7 horas sem o anticorpo, o FceRI e os gangliosídeos estão mais concentrados nas frações de lipid rafts, marcadas pela LAT. Já as proteínas quinase Lyn e Syk estão menos concentradas nos lipid rafts quando os agregados dos gangliosídeos estão presentes. Estes resultados mostram que a agregação por 8 horas dos gangliosídeos derivados do $\mathrm{GD}_{1 \mathrm{~b}}$ resulta na mobilização das proteínas Lyn e Syk, essenciais na sinalização via FceRI. Isto indica desorganização dos lipid rafts como plataforma de sinalização.

Estes resultados estão de acordo com as observações de outros estudos que mostram que em mastócitos ativados via FceRI, o receptor, os gangliosídeos derivados do GD $1 \mathrm{~b}$, a 
Lyn e demais componentes do complexo de sinalização são recrutados para os lipid rafts quando os mastócitos são ativados via FceRI, mas os microdomínios lipídicos estando desorganizados pela depleção do colesterol, o FceRI e os gangliosídeos derivados do GD 1 bão deslocados para os lipid rafts, porém, Lyn não acompanha esta redistribuição. O que resulta na baixa fosforilação dos resíduos de tirosina presentes nas subunidades $\beta$ e $\gamma$ dos ITAMs, um dos principais eventos bioquímicos envolvidos na ativação dos mastócitos via FceRI e com função de amplificação do sinal. Esses resíduos de tirosina fosforilados servem como sítios de ligação para proteínas secundárias de sinalização que dão continuidade à propagação do sinal, o que é essencial para a ativação dos mastócitos (Holowka et al, 2005; Holowka \& Baird, 2001; Rivera et al, 2001; Stauffer \& Meyer, 1997; Wilson et al, 2000). Resultado semelhante também foi observado por nosso laboratório quando há a formação dos agregados dos gangliosídeos derivados do GD $1 \mathrm{~b}$ e a subsequente ativação via FceRI. Estes achados confirmam que a integridade dos lipid rafts é necessária para que possam ocorrer às etapas inicias da transdução de sinal nestes microdomínios lipídicos.

Alguns estudos ressaltam a participação de gangliosídeos presentes em lipid rafts nos processos de sinalização celular bem como na organização destas regiões. Sabe-se que os eventos iniciais da transdução do sinal e consequente ativação dos mastócitos ocorrem nos lipid rafts (Holowka \& Baird, 2001; Sengupta et al, 2007). Embora muito discutidas a composição e a dinâmica destes microdomínios da membrana plasmática, os mecanismos moleculares de sua ação permanecem pouco conhecidos. A maioria dos estudos relatam somente o conteúdo e as propriedades dos lipid rafts como uma entidade por si só. Entretanto, trabalhos recentes têm demonstrado que a ruptura ou desorganização dos lipid rafts tem amplo efeito sobre a sinalização e os compartimentos celulares, bem como em toda a célula. As análises proteômicas destas regiões podem fornecer 
informações adicionais para o entendimento a nível funcional dos lipid rafts (Basiouni et al, 2012; Cantù et al, 2011; Holowka et al, 2005; Inder et al, 2013; Inokuchi et al, 2015; Sibilano et al, 2014; Westerlund \& Slotte, 2009).

Assim sendo, para o melhor entender o papel dos gangliosídeos derivados do GD 1 b na formação e funcionamento dos complexos de sinalização, as proteínas associadas aos lipid rafts na presença ou não de agregados destes gangliosídeos pelo mAb AA4 foram analisadas por proteômica comparativa. Este é o primeiro trabalho que traça o perfil proteômico dos lipid rafts de mastócitos, utilizando neste caso a linhagem de mastócito de rato RBL-2H3. Inicialmente, as 486 proteínas identificadas nas frações de lipid rafts foram categorizadas de acordo com os 3 principais domínios do Gene Ontology (GO). Na análise do domínio "componentes celulares", os termos "extracelular", "citoplasma" e "membrana plasmática" somaram 36\% das citações. O que caracteriza um enriquecimento positivo da técnica para o isolamento destes microdomínios lipídicos da membrana plasmática. Termos relacionados a organelas intracelulares tiveram $30 \%$ das citações. Baseado em isolamentos bioquímicos prévios, os lipid rafts podem ser encontrados em outros compartimentos além do da membrana plasmática, principalmente nas membranas mitocondriais. Os componentes dos lipid rafts se movem lateralmente na membrana plasmática bem como transitam continuamente entre a membrana plasmática e compartimentos internos. Sabe-se ainda que lipídios específicos destes microdomínios bem como proteínas associadas a eles são sintetizadas nos complexos RE/Golgi antes de serem transportados até a membrana plasmática. Portanto, diversas proteínas importantes para a síntese proteica e tráfego de vesículas foram, como esperado, identificadas nas frações de lipid rafts de mastócitos RBL-2H3 (Brown \& Rose, 1992; Foster et al, 2003; Nichols et al, 2001; Zheng \& Foster, 2009). 
A cascata de sinalização via FceRI em mastócitos é integrada as proteínas de citoesqueleto e que representaram $6,8 \%$ das citações. O citoesqueleto é composto por proteínas como actina, miosina II, tubulina e vimentina. Esses filamentos são coordenados por vias de polarização e também diretamente pela via de sinalização mediada por receptores. (Dráber et al, 2012).

$\mathrm{Na}$ categoria "processos biológicos" os maiores grupos foram relacionados pelo envolvimento nos "processos celulares", "regulação" e "resposta a estímulo" somando 58\% das citações. E por fim, na categoria "função molecular" os termos "ligação" e “atividade catalítica" somaram mais de 75\% das citações. Nesta lista de proteínas incluem proteínas que se ligam ao receptor FceRI, proteínas de citoesqueleto, receptores transmembrana, glicoproteínas de superfície celular, proteínas quinase e proteínas envolvidas no tráfego intracelular, todos estes grupos participam de diferentes aspectos na função dos mastócitos.

Os nossos resultados mostraram diversas proteínas descritas como constituintes ou associadas aos lipid rafts, bem como, proteínas envolvidas na cascata de transdução de sinal em mastócitos e que foram diferencialmente detectadas na presença ou não de agregados destes gangliosídeos pelo mAb AA4, são elas: as proteínas da família PTK, Fyn, HCK, Src, Yes, Fgr; Fyb; Lyn; SNAP-23; prorribitina 1 e 2; Blk; Btk; PKC; RACK1; Rac1; SHP-1; vimentina; vinculina; PECAM; DOK1; galectinas 1 e 3; as glicoproteínas Thy1 e TEC-21; as serina treonina quinase ICK, MAK, PAK 2; os receptores CD33, alergina-1, CD47, CD48, FC $\gamma$ RII; diversas guanina ligantes de nucleotídeos e flotilina 1(Dráber \& Dráberová, 2002; Dráberová, 1989; Holowka et al, 2005; Hálová et al, 2002; Metcalfe et al, 1997; Pyenta et al, 2001; Siraganian, 2003; Wilson et al, 2000; Zhang et al, 1998). 
Entre as proteínas up reguladas encontradas nas frações de lipid rafts, quando os gangliosídeos derivados do GD ${ }_{1 b}$ estão agregados, está a vimentina. A vimentina é uma proteína de filamento intermediário do tipo III, é a mais frequente em células mesenquimais e do tecido conjuntivo, como mastócitos (Horny et al, 1988). Os filamentos intermediários constituem o suporte estrutural no citoplasma e no núcleo e desempenham papel importante na arquitetura celular, participam da migração, no posicionamento e no transporte de organelas e na modulação da transdução de sinais. A vimentina tem um papel na regulação de complexos proteicos associados à membrana plasmática e na modulação de proteínas quinase (Dráber et al, 2012; Ivaska et al, 2007; Pallari \& Eriksson, 2006; Styers et al, 2005; Tzivion et al, 2000).

Alguns estudos relatam a importância funcional da vimentina nos lipid rafts de células epiteliais, neutrófilos e linfócitos, bem como, a sua associação a proteínas aderidas à membrana plasmática e/ou sua própria adesão à camada bilipídica (Feuk-Lagerstedt et al, 2007; Jack et al., 2005; Mielenz et al, 2005; Runembert et al, 2002; Seifert et al, 1992; $\mathrm{Wu}$ et al, 1999). Cultura primária de células tubulares renais, provenientes de camundongos $\mathrm{Vim}^{-/-}$, possuem morfologia, proliferação e atividade de hidrolases normais, porém, apresentam uma redução na atividade de co-transporte de Na-glicose. Este fenótipo está em intima associação à redução da proteína transportadora SGLT1 dos microdomínios da membrana plasmática. Estes achados foram confirmados pela depleção do colesterol de células $\operatorname{Vim}^{+/+}$, que causou a desorganização dos microdomínios e resultou numa diminuição considerável da proteína SGLT1, mas a vimentina foi encontrada nestas regiões (Runembert et al, 2002). A vimentina poderia participar na manutenção da estrutura dos lipid rafts, limitando a mobilidade lateral de proteínas específicas associadas aos microdomínios da membrana plasmática (Pallari \& Eriksson, 2006; Runembert et al, 2002). 
Nossos resultados mostram que em mastócitos RBL-2H3 que tiveram os gangliosídeos derivados do $\mathrm{GD}_{1 \mathrm{~b}}$ agregados, a vimentina está associada a estes agregados. Nestas condições os mastócitos não liberam mediadores contidos nos seus grânulos (Oliver et al, 1992; Stephan et al, 1997; Swaim et al, 1994). Em mastócitos peritoneais de rato os filamentos de vimentina se localizam circunjacentes aos grânulos citoplasmáticos. Após o estímulo via FceRI esses filamentos desapareceram, o que indica uma rápida despolimerização (Izushi et al, 1992). A ausência de filamentos circundando os grânulos facilita o movimento dos grânulos em direção à membrana plasmática e a consequente desgranulação (Tasaka, 1994). Nos mastócitos deficientes em vimentina ocorre aumento na liberação de mediadores e na fosforilação de tirosinas de proteínas intracelulares incluindo a LAT. Os nossos achados juntamente com os dados da literatura (Nahm et al, 2003; Ono et al, 2012) sugerem que a vimentina possua função regulatória na organização e funcionamento dos complexos de sinalização nos lipid rafts bem como na desgranulação de mastócitos.

A RACK1 (Receptor for Activated C Kinase 1) está entre as proteínas up reguladas encontradas nas frações de lipid rafts quando os gangliosídeos derivados do GD 1 b estão agregados. A RACK1 foi primeiramente identificada na biblioteca de cDNA de cérebro de rato em busca de proteínas âncoras que se associavam a proteína quinase $\mathrm{C}$ (PKC) na presença de seus ativadores diacilglicerol, cálcio e fosfatidilserina. Quando esta interação é inibida ocorre a desestabilização de PKC e a redução da fosforilação de seus substratos (Mochly-Rosen et al, 1991; Mochly-Rosen et al, 1995; Ron et al, 1994). A RACK1 não possui atividade catalítica o que sugere sua função como proteína scaffold. A RACK1 está envolvida na estrutura celular e em outros processos celulares, tais como: crescimento, proliferação, movimento, morte e sobrevivência (Gandin et al, 2013). Recentemente foi descrito o seu papel em vias de sinalização e na distribuição e 
estabilização de proteínas na membrana plasmática (Adams et al, 2011; Shuangding Li et al, 2011).

Embora a RACK1 não tenha sido investigada em mastócitos, uma análise sistemática de genes interelacionados à asma identificou um possível e importante papel do gene GNB2L1, codificador para expressão de RACK1, na via de interação gênica da asma. Este gene apresentou interações com outros genes codificadores de proteínas chave na sinalização celular, sugerindo ser de grande valia à investigação de sua função nesta patologia (Hwang et al, 2008).

Já foram descritas mais de 100 proteínas que podem interagir com a RACK1 de forma direta ou via complexos macromoleculares, estando a RACK1 ligada a outras proteínas de forma constitutiva (por exemplo, Src) ou ligada de forma transitória via dependente de estímulo (por exemplo, PKC $\beta$ ). Dentre estas 100 proteínas descritas algumas participam da via de sinalização dos mastócitos, tais como: $\operatorname{Src}, \operatorname{PKC}(\beta$ e $\delta)$; STAT3; JAK; Fyn; JNK; Gab2; Grb2 e NFAT1 (Ronai et al, 2013). Com exceção de NFAT1, estas proteínas também foram identificadas neste estudo através da análise proteômica.

A função de RACK1 varia dependendo da sua ligação com as diferentes proteínas. Por exemplo, a RACK1 pode carrear as proteínas que estão ligadas a ela para os seus sítios de ação, como a PKC, facilitando a interação de seu ligante com as distintas vias de sinalização ou recrutando outras proteínas destas vias (Lopez-Bergami et al, 2005). Nossos resultados da proteômica mostram PKC $\beta$ e PKC $\delta$ nas frações de lipid rafts

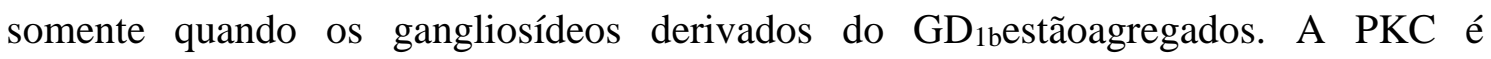
multifuncional e fosforila radicais serina e treonina de muitas proteínas alvo, porém só é enzimaticamente ativa na presença de $\mathrm{Ca}^{2+}$ e fosfatidilserina. A ativação desta via resulta na desgranulação quando os mastócitos são estimulados via FceRI (Riviera \& Gilfillan, 
2006). Apesar do aumento intracelular de cálcio demonstrado por Oliver et al. (1992) e da redistribuição de RACK1 e PKC observada em nossa análise proteômica, não ocorre desgranulação via FceRI de mastócitos RBL-2H3 (Oliver et al, 2007) quando os gangliosídeos derivados do $\mathrm{GD}_{1 \mathrm{~b}}$, estão agregados. Isto indica, que nesta condição, somente a redistribuição e ativação de PKC não é suficiente para desencadear a desgranulação.

A ligação de RACK1 com proteínas quinase pode resultar no aumento (JNK, MAPKs) ou diminuição (Src) da atividade catalítica destas proteínas. RACK1 suprime a atividade da tirosina quinase Src e Fyn na membrana plasmática de fibroblastos (células NHI 3T3). Uma vez que RACK1 está ligada a essas proteínas quinase, elas são impedidas de fosforilarem seus substratos (Chang et al, 1998; Chang et al, 2001; Yaka et al, 2002; Yaka 2003). Estudo realizado por Plate e colaboradores (2013) mostrou que Lyn e PKC formam complexos com RACK1 na membrana plasmática em associação aos receptores EGFR em células tumorais de pulmão. As proteínas quinase Src, Fyn e Lyn são reguladores positivos na ativação e desgranulação dos mastócitos (Kalesnikoff \& Galli, 2008; Siraganian et al, 2003). Em nossa análise proteômica a PTK Lyn está reduzida nas frações de lipid rafts quando os gangliosídeos derivados do GD 1 b estão agregados e as PTKs Src e Fyn foram identificadas somente nas frações de lipid rafts quando os agregados dos gangliosídeos derivados do $\mathrm{GD}_{1 \mathrm{~b}}$ não estavam presentes, sugerindo uma possível relação de RACK1 e estas tirosinas quinase nos mastócitos.

Estudo recente demonstrou que RACK1 é reguladora negativa na sinalização

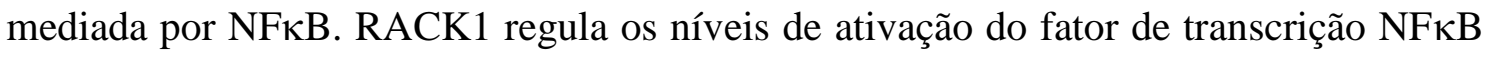
em resposta a diferentes intensidades de estímulo em macrófagos modulando a interação entre TRAF2 e IKK, ressaltando um novo papel para RACK1 na regulação negativa de reações inflamatórias (Yao et al, 20014). Os nossos resultados demostraram que o 
intercruzamento dos gangliosídeos derivados do $\mathrm{GD}_{1 b}$ pelo mAb AA4 resulta na ativação do fator de transcrição NFאB. Esta ativação é menor em relação à mediada por FceRI (Grodzki et al, 2009), sugerindo que RACK1, uma vez aumentada nas frações de lipid rafts quando os gangliosídeos derivados do $\mathrm{GD}_{1 \mathrm{~b}}$ estão agregados, poderia contribuir para a diminuição da ativação de NFאB observada nestas condições.

Diversos estudos relatam a interação de RACK1 com a calda citoplasmática de vários receptores incluindo: Insulin-like Growth Factor Receptor I (IGF-IR); $\beta$-integrina; IL-5; IL-3; GM-CSF; Inositol 1,4,5-triphosphate Receptor (IP3R) e diversos canais iônicos. A interação de RACK1 com os domínios intracelulares dos receptores transmembranas resulta na regulação positiva ou negativa da função destes receptores. Sendo assim, maior atenção tem sido dada a RACK1 como um eixo nas diferentes vias de transdução de sinal (Patterson et al, 2004; Usacheva et al, 2001; Yang et al, 2012; Zhang et al, 2006).

Nossos resultados somados aos dados da literatura aqui descritos sugerem que RACK1 possa estar envolvida na organização e funcionamento dos complexos de sinalização nos lipid rafts de mastócitos.

Nossos resultados demonstram que o receptor FC $\gamma$ RII (Low affinity Fc gamma receptor IIB) está up regulado nas frações de lipid rafts quando os gangliosídeos derivados do $\mathrm{GD}_{1 \mathrm{~b}}$ estão agregados. O FC $\gamma \mathrm{RII}$ possui um domínio intracitoplasmático contendo immunoreceptor tyrosine-based inhibition motif (ITIM) que pode influenciar na ativação via FceRI. Uma vez ligado ao FceRI, FC $\gamma$ RII recruta a inositol fosfatase SHIP1, as proteínas DOK-1 e DOK-2 e a proteína tirosina fosfatase SHP-1 para a membrana, inibindo a desgranulação e a liberação de mediadores inflamatórios pelos mastócitos (Gilfillan \& Beaven, 2011; MacGlashan Jr et al, 2013; Malbec et al, 1998; Ono et al, 1996; Ravetch \& Bolland, 2001). O receptor alergina-1 contém um domínio 
immunoreceptor tyrosine-based inibitory motif (ITIM)-like e é preferencialmente expresso em mastócitos. O alergina-1 foi identificado em nossa análise proteômica somente nas frações de lipid rafts quando os gangliosídeos derivados do GD $1 \mathrm{~b}$ estão agregados. O receptor alergina-1 recruta, assim como FC $\gamma$ RII, a SHIP1 e a SHP-1. A agregação de alergina-1 com FceRI suprime a desgranulação de mastócitos BMMCs (Bone Marrow-derived Mononuclear Cells). Ainda, os camundongos deficientes em alergina-1 desenvolvem anafilaxia passiva sistêmica e cutânea. Reforçando o papel regulatório negativo de alergina-1 na desgranulação dos mastócitos (Hitomi et al, 2010).

A proteína tirosina fosfatase SHP-1 (Tyrosine-protein phosphatase non-receptor type 6), a DOK-1 (Docking protein 1) e a PECAM-1 (Platelet Endotelial Cell Adhesion Molecule 1) foram identificadas pelo proteoma somente nas frações de lipid rafts obtidas de mastócitos RBL-2H3, com os gangliosídeos derivados do $\mathrm{GD}_{1 \mathrm{~b}}$ agregados. Diversos estudos têm descrito estas proteínas como reguladores negativos da desgranulação em mastócitos (Bounab et al, 2013; Daeron et al, 2008; Pfirsch-Maisonnas et al, 2011; Siraganian, 2003; Song et al, 2002; Udell et al, 2006). As SHPs são efetoras negativas na regulação da ativação celular da maioria dos receptores inibitórios e sua expressão é restrita a células da linhagem hematopoiética. O recrutamento de SHP-1 pelos domínios ITIM fosforilados dos receptores aumenta a atividade desta fosfatase, levando a desfosforilação das tirosinas presentes nas moléculas de sinalização. Interessantemente, SHP-1 provavelmente desfosforila os domínios ITIMs, servindo como feedback regulatório na sinalização inibitória. A perda da função de SHP-1 leva a ao aumento da fosforilação de Syk e a um fenótipo hiperesponsivo nos mastócitos (Bounab et al, 2013; Daeron et al, 2008; Lorenz, 2009; Pfirsch-Maisonnas et al. 2011; Zhang et al, 2010).

Outra proteína identificada pelo proteoma somente nas frações de lipid rafts quando os gangliosídeos derivados do $\mathrm{GD}_{1 \mathrm{~b}}$ estavam agregados é a Pak2. A Pak2 é altamente 
expressa em mastócitos e a inibição desta proteína induz o aumento na desgranulação e na liberação de citocinas via FceRI, refletindo na sua função inibitória na desgranulação dos mastócitos (Kosoff et al, 2013).

Duas proteínas ancoradas por GPI (glicosilfosfatidilinositol), a Thy1 e a TEC-21 classificadas pela análise proteômica no grupo de proteínas down reguladas nos lipid rafts, quando os gangliosídeos derivados do $\mathrm{GD}_{1 \mathrm{~b}}$ estão agregados, se apresentaram aumentas nas análises bioquímicas destas frações. Alguns estudos sugerem que os resíduos de glicanas presentes nas proteínas ancoradas por GPI podem interferir na identificação destas proteínas pela proteômica, por serem menos susceptíveis as proteases (Castillo et al, 2008; Edge, 2003). Nossos resultados mostram estas proteínas ancoradas por GPI estão mais glicosiladas nas frações de lipid rafts, após a agregação dos gangliosídeos. Isto poderia interferir de forma significativa na ação da tripsina e, consequentemente na identificação destas proteínas pela técnica de $\operatorname{NanoUPLC}_{\mathrm{M}} \mathrm{MS}^{\mathrm{E}}, \mathrm{o}$ que resulta em falso negativo.

A TEC-21 é abundante na superfície de mastócitos RBL-2H3 (>10\%/célula), mas ausentes em vários tecidos de rato exceto nos testículos. A agregação de TEC-21 em mastócitos RBL-2H3 induz ao rápido aumento da fosforilação da PTK Syk e LAT e do influxo de cálcio e induz também a liberação de componentes secretórios, porém, os eventos são menos pronunciados que àqueles observados na ativação celular via Fc\&RI. Entretanto, a agregação de TEC-21 não induz a fosforilação das subunidades $\beta$ e $\gamma$ do FceRI e co-agregação com a proteína quinase Lyn. Além do mais, ao contrário de outros componentes dos lipid rafts, a ativação induzida pela agregação de TEC-21 é independente do FceRI (Hálová et al, 2002).

A Thy-1 é uma das moléculas mais abundantes expressas na superfície dos mastócitos RBL-2H3 ( 10\% célula). Thy-1 interage com a PTK Lyn e ambas estão 
presentes nos complexos proteicos insolúveis em detergente, uma vez que na ausência do colesterol, um dos principais constituintes dos lipid rafts, essa interação é desfeita. A Thy1 se localiza nos gradientes de sacarose antes e após a depleção do colesterol, semelhantemente ao que ocorre com os gangliosídeos derivados do GD 1 b. A agregação de Thy-1 por mAb específico leva a indução da ativação celular semelhante à observada via Fc\&RI, porém, em menor extensão. Em mastócitos ativados via FceRI, Thy-1 juntamente com o receptor e os componentes do complexo de sinalização são recrutados para os lipid rafts. E ainda, os lipid rafts desempenham papel crucial na ativação de mastócitos mediada por Thy-1 (Dráberová, 1989; Dráberová et al, 1996; Dráberová \& Dráber, 1993; Holowka \& Baird, 2001; Surviladze et al, 1998).

A PTK Lyn está down regulada quando os gangliosídeos derivados do $\mathrm{GD}_{1 \mathrm{~b}}$ estão agregados. Nossos resultados mostram que a formação de agregados de gangliosídeos derivados do $\mathrm{GD}_{1 \mathrm{~b}}$, resulta na diminuição de Lyn nas frações de lipid rafts e a sua distribuição em frações não rafts. Imediatamente após o seu intercruzamento, os FceRIs se deslocam para os lipid rafts e, nessas regiões, aumenta a concentração de Lyn, responsável pela fosforilação dos imunoreceptores ITAM (Immunoreceptor Tyrosinebased Activation Motif), presentes nos domínios citoplasmáticos das subunidades $\beta$ e $\gamma$ do receptor (Metzger, 1992; Siraganian et al, 2010; Wilson et al, 2001). Baird e colaboradores (2003) propuseram que após ativação via FcદRI os lipid rafts excluiriam destas regiões as fosfatases, que regulam negativamente a atividade de Lyn e outras proteínas da via de sinalização pela desfosforilação dos seus domínios tirosina quinase, promovendo assim a proximidade de Lyn ativa nestes microdomínios da membrana, o que foi posteriormente confirmado por Mahajan e colaboradores (2014). Com a depleção do colesterol, as regiões de microdomínios da membrana plasmática ficam desestabilizadas e, após o intercruzamento, os FceRIs ainda são deslocados para os lipid 
rafts. Entretanto, a Lyn não se localiza junto com os receptores nos lipid rafts quando desestabilizados (de Castro et al, 2010; Siraganian, 2003; Underhill \& Goodridge, 2007; Zhang et al, 2000). Swaim et al, (1994) observaram uma associação específica de Lyn com os gangliosídeos derivados do $\mathrm{GD}_{1 \mathrm{~b}}$ sendo mais intensa que a associação com FceRI. Outros estudos demonstram que esses gangliosídeos co-precipitam com Lyn e que essa associação é devido à presença dos microdomínios na membrana plasmática (Brown \& London, 1998; Brown \& Rose, 1992; Minoguchi et al, 1994). Este conjunto de dados mostra que a diminuição de Lyn nas frações de lipid rafts é resultado dadesorganização destes microdomínios como plataforma de sinalização que ocorre quando os gangliosídeos derivados do $\mathrm{GD}_{1 \mathrm{~b}}$ estão agregados, o que resulta no comprometimento das etapas iniciais da via de transdução de sinal dos mastócitos.

As proteínas da família Src tirosina quinases (PTK) são críticas para o início da resposta dos mastócitos ativados via FceRI e para a sua regulação. A fosforilação das tirosinas é um dos eventos iniciais da transdução de sinal, após a agregação dos FceRI, desempenhando papel essencial nesta via (Poderycki et al, 2010; Siraganian et al, 2010; Zhang et al, 2010). Mastócitos de camundongos $\mathrm{Lyn}^{-/}$apresentam desgranulação via FceRI normal ou aumentada, o que sugere que outras tirosina quinases possam compensar a atividade de Lyn (Beavitt et al, 2005). Além da Lyn, outras PTKs (Fyn; Hck; Fgr; Yes e Src) foram detectadas e estavam down reguladas quando os gangliosídeos derivados do $\mathrm{GD}_{1 \mathrm{~b}}$ estão agregados.

A PTK Fyn medeia a fosforilação do adaptador Gab2 e, subsequentemente, ativa PI3K e a translocação dos grânulos dependente de microtúbulos. Estes eventos são cruciais para que a ocorra a ativação e desgranulação dos mastócitos. A Hck regula positivamente a ativação dos mastócitos via Fc\&RI, através da fosforilação dos resíduos de tirosina nos domínios ITAMs da subunidade $\beta$ do receptor e regula a atividade de Lyn. 
Mastócitos deficientes em Fyn e Hck tiveram atividade biológica reduzida, indicando que essas PTKs contribuem substancialmente na via de sinalização requerida para ativação dos mastócitos (Galli \& Kalesnikoff, 2008; Hong et al, 2007; Nishida et al, 2005; Parravicini et al, 2002). A PTK Fgr associa-se com FceRI, fosforila Syk e age como reguladora positiva na desgranulação e produção de mediadores neoformados e neosintetizados pelos mastócitos. Recentemente tem sido demonstrado que a ativação de FceRI por antígenos de baixa afinidade requer a PTK Fgr (Lee et al, 2011, Suzuki et al, 2014).

A análise bioquímica mostrara que a Syk está menos concentrada nas frações de lipid rafts quando os gangliosídeos derivados do GD 1 b estão agregados. Porém, a PTK Syk não foi identificada em nossa análise proteômica. Os domínios ITAMs fosforilados servem como sítio de ligação para Syk, está ligação resulta em mudança conformacional de Syk aumentando sua atividade enzimática. Uma vez ativada, Syk se autofosforila desencadeando a propagação do sinal. Syk fosforila então as proteínas adaptadoras LAT1 e NTAL, ativando a via PI3K e da PTK Btk. Embora as diversas proteínas PTKs tenham sido implicadas na sinalização mediada via FceRI, somente a ausência de Syk resulta na completa inibição da desgranulação e liberação de citocinas. Mastócitos deficientes em Syk apresentam defeitos na maioria dos eventos de sinalização após estímulo via FceRI, porém são exceção: as fosforilações das tirosinas presentes nas subunidades do receptor e das proteínas regulatórias negativas SHIP1, SHP-1 e SHP-2 (de Castro et al, 2010; Grodzki et al, 2009; Minoguchi et al, 1994; Siraganian et al, 2010; Zhang et al, 2000).

O balanço entre proteínas PTKs e as fosfatases regulam as fosforilações da via de sinalização dos mastócitos. Essas proteínas foram, em sua maioria, identificadas em nossa análise proteômica quando os agregados dos gangliosídeos derivados do GD $\mathrm{Gb}_{1 \mathrm{~b}}$ estão presentes. 
Outras proteínas como a prorribitina (PHB) e a SNAP-23 (Synaptosomal associated protein 23) também estão down reguladas em nossa análise proteômica dos lipid rafts de mastócitos com gangliosídeos derivados do $\mathrm{GD}_{1 \mathrm{~b}}$ agregados. Estas proteínas tem um papel na via de sinalização dos mastócitos. A PHB é abundante nos grânulos intracelulares dos mastócitos. O Knockdown de PHB em mastócitos resultou na inibição da sinalização mediada via FcદRI, desgranulação e secreção de citocinas. Interessantemente, a diminuição de PHB inibiu a associação de Syk com o FceRI e inibiu a ativação de Syk. A PHB é translocada dos grânulos intracelulares para os lipid rafts e fosforilada por Lyn em resposta ao antígeno. No Knockdown de PHB o movimento de FceRI e Syk para estas regiões de microdomínios na membrana plasmática está inibido. In vivo, a diminuição de PHB induz a anafilaxia passiva cutânea e sistêmica. Esses resultados sugerem que PHB é essencial na ativação dos mastócitos mediada por FceRI (Kim et al, 2013, Yurugi et al, 2013). A SNAP-23 pertence ao grande grupo de proteínas SNAREs (Soluble $\mathrm{N}$-ethylmaleimide-sensitive fator attachment protein receptors) que são requeridas para a fusão das vesículas intracelulares com a membrana plasmática (Sudhof \& Rizo, 2011). A superexpreção de SNAP-23 aumenta a exocitose dos mastócitos e no seu Knockdown a desgranulação via FceRI está reduzida (Frank et al, 2011, Vaidyanathan et al, 2001). Quando os mastócitos são estimulados via FceRI na presença do mAb AA4 a liberação de histamina e $\beta$-hexosaminidase são diminuídas de modo dose e tempo dependentes (Basciano et al, 1986; Oliver et al, 2007). A redução de SNAP-23 demonstrada em nossa análise proteômica, quando os gangliosídeos derivados do $\mathrm{GD}_{1 \mathrm{~b}}$ estão agregados pelo mAb AA4, pode estar relacionada com a inibição da desgranulação nestas condições.

O CD48 está down regulado quando os agregados dos gangliosídeos derivados do $\mathrm{GD}_{1 \mathrm{~b}}$ estão agregados. O CD48 não possui domínio intracelular, mas em linfócitos, o 
estímulo através de CD48 induz à reorganização das moléculas de sinalização nos lipid rafts e a fosforilação de tirosinas. Porém, o papel de CD48 nos mastócitos ainda não está totalmente elucidado (Boles et al, 2001; Elishmereni \& Schaffer, 2011; Milstein et al, 2008). A diminuição expressiva de CD48 identificada pelo nosso proteoma nas frações de lipid rafts quando os microdomínios estão desorganizados pela a agregação dos gangliosídeos derivados do $\mathrm{GD}_{1 \mathrm{~b}}$, sugere que este receptor seja importante para organização destes microdomínios em mastócitos.

Nossos resultados mostram que proteínas com função regulatória negativa na ativação e desgranulação dos mastócitos estão up reguladas, enquanto proteínas que são críticas para a transdução do sinal e reguladoras positivas da via de sinalização estão down reguladas nas frações de lipid rafts, quando os gangliosídeos derivados do $\mathrm{GD}_{1 \mathrm{~b}}$ estão agregados. Isto sugere que na inibição da liberação de histamina e $\beta$-hexosaminidase, via FceRI, em mastócitos incubados com mAb AA4 por 8 horas, ocorre a desorganização dos lipid rafts que servem como plataforma de sinalização.

Os resultados obtidos neste trabalho mostram que os gangliosídeos derivados do $\mathrm{GD}_{1 b}$ são moduladores importantes da liberação de mediadores de mastócitos. A agregação de gangliosídeos derivados do $\mathrm{GD}_{1 \mathrm{~b}}$ pelo mAb AA4 leva a desorganização dos lipid rafts, o que resulta na redistribuição de proteínas associadas a estes microdomínios da membrana plasmática. E ainda, o intercruzamento dos gangliosídeos derivados do GD 1 bé capaz de induzir os mastócitos a liberarem mediadores neo-sintetizados, mas não os mediadores neoformados. 


\section{CONCLUSÕES}

Com base nos resultados obtidos neste trabalho concluímos que os gangliosídeos derivados do $\mathrm{GD}_{1 \mathrm{~b}}$ modulam a liberação dos mediadores dos mastócitos:

- O intercruzamento dos gangliosídeos derivados do $\mathrm{GD}_{1 b}$ ativa os fatores de transcrição NFAT e NFkB e induz a liberação de fatores neo-sintetizados;

- O intercruzamento dos gangliosídeos derivados do $\mathrm{GD}_{1 b}$ não induz a liberação de mediadores neoformados;

- A agregação dos gangliosídeos derivados do $\mathrm{GD}_{1 \mathrm{~b}}$ resulta na redistribuição das proteínas dos lipid rafts. 


\section{REFERÊNCIAS BIBLIOGRÁFICAS}




\section{REFERÊNCIAS BIBLIOGRÁFICAS}

Abramson J, Rozenblum G, Pecht I (2003) Dok protein family members are involved in signaling mediated by the type 1 Fcepsilon receptor. Eur J Immunol33: 85-91

Abrink M, Grujic M, Pejler G (2004) Serglycin is essential for maturation of mast cell secretory granule. J Biol Chem 279: 40897-40905

Abulrob A, Lu Z, Brunette E, Pulla D, Stanimirovic D, Johnston LJ (2008) Near-field scanning optical microscopy detects nanoscale glycolipid domains in the plasma membrane. J Microsc 232: 225-234

Adams DR, Ron D, Kiely PA (2011) RACK1, A multifaceted scaffolding protein: Structure and function. Cell Commun Signal9: 22

Anand P, Singh B, Jaggi AS, Singh N (2012) Mast cells: an expanding pathophysiological role from allergy to other disorders. Naunyn Schmiedebergs Arch Pharmacol385: 657670

Anderson RG, Jacobson K (2002) A role for lipid shells in targeting proteins to caveolae, rafts, and other lipid domains. Science 296: 1821-1825

Baba Y, Nishida K, Fujii Y, Hirano T, Hikida M, Kurosaki T (2008) Essential function for the calcium sensor STIM1 in mast cell activation and anaphylactic responses. Nat Immunol9: 81-88

Basciano LK, Berenstein EH, Kmak L, Siraganian RP (1986) Monoclonal antibodies that inhibit IgE binding. J Biol Chem261: 11823-11831

Basiouni S, Stöckel K, Fuhrmann H, Schumann J (2012) Polyunsaturated fatty acid supplements modulate mast cell membrane microdomain composition. Cell Immunol275: $42-46$

Beavitt SJ, Harder KW, Kemp JM, Jones J, Quilici C, Casagranda F, Lam E, Turner D, Brennan S, Sly PD, Tarlinton DM, Anderson GP, Hibbs ML (2005) Lyn-deficient mice 
develop severe, persistent asthma: Lyn is a critical negative regulator of Th2 immunity. J Immunol175: 1867-1875

Benhamou M, Ryba NJ, Kihara H, Nishikata H, Siraganian RP (1993) Protein-tyrosine kinase p72syk in high affinity $\mathrm{IgE}$ receptor signaling. Identification as a component of pp72 and association with the receptor gamma chain after receptor aggregation. $J$ Biol Chem 268: 23318-23324

Benhamou M, Siraganian R (1992) Protein-tyrosine phosphorylation: an essential component of Fc epsilon RI signaling. Immunol Today13: 195-197

Benhamou M, Stephan V, Robbins KC, Siraganian RP (1992) High-affinity IgE receptormediated stimulation of rat basophilic leukemia (RBL-2H3) cells induces early and late protein-tyrosine phosphorylations. J Biol Chem267: 7310-7314

Bini L, Pacini S, Liberatori S, Valensin S, Pellegrini M, Raggiaschi R, Pallini V, Baldari CT (2003) Extensive temporally regulated reorganization of the lipid raft proteome following T-cell antigen receptor triggering. Biochem J369: 301-309

Birklé S, Zeng G, Gao L, Yu RK, Aubry J (2003) Role of tumor-associated gangliosides in cancer progression. Biochimie85: 455-463

Boles KS, Stepp SE, Bennett M, Kumar V, Mathew PA (2001) 2B4 (CD244) and CS1: novel members of the CD2 subset of the immunoglobulin superfamily molecules expressed on natural killer cells and other leukocytes. Immunol Rev181: 234-249

Bounab Y, Getahun A, Cambier JC, Daëron M (2013) Phosphatase regulation of immunoreceptor signaling in T cells, B cells and mast cells. Curr Opin Immunol25: 313320

Boyce JA (2007) Mast cells and eicosanoid mediators: a system of reciprocal paracrine and autocrine regulation. Immunol Rev217: 168-185

Brown DA, London E (1998) Functions of lipid rafts in biological membranes. Annu Rev Cell Dev Biol14: 111-136 
Brown DA, Rose JK (1992) Sorting of GPI-anchored proteins to glycolipid-enriched membrane subdomains during transport to the apical cell surface. Cell68: 533-544

Cambier JC (1995) Antigen and Fc receptor signaling. The awesome power of the immunoreceptor tyrosine-based activation motif (ITAM). J Immunol155: 3281-3285

Cantù L, Del Favero E, Sonnino S, Prinetti A (2011) Gangliosides and the multiscale modulation of membrane structure. Chem Phys Lipids164: 796-810

Castillo L, Calvo E, Martínez AI, Ruiz-Herrera J, Valentín E, Lopez JA, Sentandreu R (2008) A study of the Candida albicans cell wall proteome. Proteomics8: 3871-3881

Cebecauer M, Owen DM, Markiewicz A, Magee AI (2009) Lipid order and molecular assemblies in the plasma membrane of eukaryotic cells. Biochem Soc Trans37: 10561060

Chang BY, Chiang M, Cartwright CA (2001) The interaction of Src and RACK1 is enhanced by activation of protein kinase $\mathrm{C}$ and tyrosine phosphorylation of RACK1. $J$ Biol Chem276: 20346-20356

Chang SH, Oh CD, Yang MS, Kang SS, Lee YS, Sonn JK, Chun JS (1998) Protein kinase $\mathrm{C}$ regulates chondrogenesis of mesenchymes via mitogen-activated protein kinase signaling. J Biol Chem273: 19213-19219

Cook EB, Stahl JL, Sedgwick JB, Barney NP, Graziano FM (2004) The promotion of eosinophil degranulation and adhesion to conjunctival epithelial cells by IgE-activated conjunctival mast cells. Ann Allergy Asthma Immunol92: 65-72

Daëron M, Jaeger S, Du Pasquier L, Vivier E (2008) Immunoreceptor tyrosine-based inhibition motifs: a quest in the past and future. Immunol Rev224: 11-43

da Silva EZ, Jamur MC, Oliver C (2014) Mast cell function: a new vision of an old cell. J Histochem Cytochem62: 698-738 
de Castro RO, Zhang J, Jamur MC, Oliver C, Siraganian RP (2010) Tyrosines in the carboxyl terminus regulate Syk kinase activity and function. J Biol Chem285: 2667426684

de Souza DA, Toso VD, Campos MR, Lara VS, Oliver C, Jamur MC (2012) Expression of mast cell proteases correlates with mast cell maturation and angiogenesis during tumor progression. PLoS One7: e40790

Dráber P, Dráberová L (2002) Lipid rafts in mast cell signaling. Mol Immunol38: 12471252

Dráber P, Sulimenko V, Dráberová E (2012) Cytoskeleton in mast cell signaling. Front Immunol3: 130

Dráberová L (1989) The involvement of Thy-1 antigen in the activation of rat mast cells. Eur J Immunol19: 1715-1720

Dráberová L, Amoui M, Dráber P (1996) Thy-1-mediated activation of rat mast cells: the role of Thy-1 membrane microdomains. Immunology87: 141-148

Edge AS (2003) Deglycosylation of glycoproteins with trifluoromethanesulphonic acid: elucidation of molecular structure and function. Biochem J376: 339-350

Eggeling C, Ringemann C, Medda R, Schwarzmann G, Sandhoff K, Polyakova S, Belov VN, Hein B, von Middendorff C, Schönle A, Hell SW (2009) Direct observation of the nanoscale dynamics of membrane lipids in a living cell. Nature457: 1159-1162

Elishmereni M, Levi-Schaffer F (2011) CD48: A co-stimulatory receptor of immunity. Int J Biochem Cell Biol43: 25-28

Feuk-Lagerstedt E, Movitz C, Pellmé S, Dahlgren C, Karlsson A (2007) Lipid raft proteome of the human neutrophil azurophil granule. Proteomics7: 194-205

Foster LJ, Chan QW (2007) Lipid raft proteomics: more than just detergent-resistant membranes. Subcell Biochem43: 35-47 
Foster LJ, De Hoog CL, Mann M (2003) Unbiased quantitative proteomics of lipid rafts reveals high specificity for signaling factors. Proc Natl Acad Sci U S A100: 5813-5818

Frank SP, Thon KP, Bischoff SC, Lorentz A (2011) SNAP-23 and syntaxin-3 are required for chemokine release by mature human mast cells. Mol Immunol49: 353-358

Galli SJ, Borregaard N, Wynn TA (2011) Phenotypic and functional plasticity of cells of innate immunity: macrophages, mast cells and neutrophils. Nat Immunol12: 1035-1044

Galli SJ, Kalesnikoff J, Grimbaldeston MA, Piliponsky AM, Williams CM, Tsai M (2005) Mast cells as "tunable" effector and immunoregulatory cells: recent advances. Aпnu Rev Immunol23: 749-786

Gammon CM, Ledeen RW (1985) Evidence for the presence of a ganglioside transfer protein in brain. $J$ Neurochem $44:$ 979-982

Gandin V, Gutierrez GJ, Brill LM, Varsano T, Feng Y, Aza-Blanc P, Au Q, McLaughlan S, Ferreira TA, Alain T, Sonenberg N, Topisirovic I, Ronai ZA (2013) Degradation of newly synthesized polypeptides by ribosome-associated RACK1/c-Jun N-terminal kinase/eukaryotic elongation factor 1A2 complex. Mol Cell Biol33: 2510-2526

Gilfillan AM, Beaven MA (2011) Regulation of mast cell responses in health and disease. Crit Rev Immunol31: 475-529

Gilfillan AM, Tkaczyk C (2006) Integrated signalling pathways for mast-cell activation. Nat Rev Immunol6: 218-230

Gonzalez-Espinosa C, Odom S, Olivera A, Hobson JP, Martinez ME, Oliveira-DosSantos A, Barra L, Spiegel S, Penninger JM, Rivera J (2003) Preferential signaling and induction of allergy-promoting lymphokines upon weak stimulation of the high affinity IgE receptor on mast cells. J Exp Med197: 1453-1465

Gordon JR, Galli SJ (1990) Mast cells as a source of both preformed and immunologically inducible TNF-alpha/cachectin. Nature346: 274-276 
Grodzki AC, Moon KD, Berenstein EH, Siraganian RP (2009) FcepsilonRI-induced activation by low antigen concentrations results in nuclear signals in the absence of degranulation. Mol Immunol46: 2539-2547

Gunter KC, Malek TR, Shevach EM (1984) T cell-activating properties of an anti-Thy-1 monoclonal antibody. Possible analogy to OKT3/Leu-4. J Exp Med159: 716-730

Guo NH, Her GR, Reinhold VN, Brennan MJ, Siraganian RP, Ginsburg V (1989) Monoclonal antibody AA4, which inhibits binding of IgE to high affinity receptors on rat basophilic leukemia cells, binds to novel alpha-galactosyl derivatives of ganglioside GD1b. J Biol Chem264: 13267-13272

Gwack Y, Feske S, Srikanth S, Hogan PG, Rao A (2007) Signalling to transcription: store-operated Ca2+ entry and NFAT activation in lymphocytes. Cell Calcium42: 145156

Hálová I, Dráberová L, Dráber P (2002) A novel lipid raft-associated glycoprotein, TEC21 , activates rat basophilic leukemia cells independently of the type $1 \mathrm{Fc}$ epsilon receptor. Int Immunol14: 213-223

Hakomori S, Igarashi Y (1993) Gangliosides and glycosphingolipids as modulators of cell growth, adhesion, and transmembrane signaling. Adv Lipid Res25: 147-162

Hakomori SI, Handa K (2015) GM3 and cancer. Glycoconj J

Hanai N, Nores GA, MacLeod C, Torres-Mendez CR, Hakomori S (1988) Gangliosidemediated modulation of cell growth. Specific effects of GM3 and lyso-GM3 in tyrosine phosphorylation of the epidermal growth factor receptor. J Biol Chem263: 10915-10921

Harder T, Scheiffele P, Verkade P, Simons K (1998) Lipid domain structure of the plasma membrane revealed by patching of membrane components. J Cell Biol141: 929-942

Hernandez-Hansen V, Smith AJ, Surviladze Z, Chigaev A, Mazel T, Kalesnikoff J, Lowell CA, Krystal G, Sklar LA, Wilson BS, Oliver JM (2004) Dysregulated FcepsilonRI signaling and altered Fyn and SHIP activities in Lyn-deficient mast cells. J Immunol173: $100-112$ 
Hitomi T, Zhang J, Nicoletti LM, Grodzki AC, Jamur MC, Oliver C, Siraganian RP (2004) Phospholipase D1 regulates high-affinity IgE receptor-induced mast cell degranulation. Blood104: 4122-4128

Hoesel B, Schmid JA (2013) The complexity of NF- $\kappa$ B signaling in inflammation and cancer. Mol Cancer12: 86

Holowka D, Baird B (2001) Fc(epsilon)RI as a paradigm for a lipid raft-dependent receptor in hematopoietic cells. Semin Immunol13: 99-105

Holowka D, Gosse JA, Hammond AT, Han X, Sengupta P, Smith NL, WagenknechtWiesner A, Wu M, Young RM, Baird B (2005) Lipid segregation and IgE receptor signaling: a decade of progress. Biochim Biophys Acta1746: 252-259

Holowka D, Sheets ED, Baird B (2000) Interactions between Fc(epsilon)RI and lipid raft components are regulated by the actin cytoskeleton. J Cell Sci113 ( Pt 6): 1009-1019

Hong H, Kitaura J, Xiao W, Horejsi V, Ra C, Lowell CA, Kawakami Y, Kawakami T (2007) The Src family kinase Hck regulates mast cell activation by suppressing an inhibitory Src family kinase Lyn. Blood110: 2511-2519

Horny HP, Kaiserling E (1988) Lymphoid cells and tissue mast cells of bone marrow lesions in systemic mastocytosis: a histological and immunohistological study. $\mathrm{Br} J$ Haematol69: 449-455

Huber M, Gibbs BF (2015) SHIP1 and the negative control of mast cell/basophil activation by supra-optimal antigen concentrations. Mol Immunol63: 32-37

Hu ZQ, Zhao WH, Shimamura T (2007) Regulation of mast cell development by inflammatory factors. Curr Med Chem14: 3044-3050

Hwang S, Son SW, Kim SC, Kim YJ, Jeong H, Lee D (2008) A protein interaction network associated with asthma. J Theor Biol252: 722-731 
Ikami T, Ishida H, Kiso M (2000) Synthesis and biological activity of glycolipids, with a focus on gangliosides and sulfatide analogs. Methods Enzymol311: 547-568

Inder KL, Davis M, Hill MM (2013) Ripples in the pond--using a systems approach to decipher the cellular functions of membrane microdomains. Mol Biosyst 9: 330-338

Inokuchi J, Nagafuku M, Ohno I, Suzuki A (2015) Distinct selectivity of gangliosides required for $\mathrm{CD}^{+} \mathrm{T}$ and $\mathrm{CD} 8^{+} \mathrm{T}$ cell activation. Biochim Biophys Acta1851: 98-106

Irani AA, Schechter NM, Craig SS, DeBlois G, Schwartz LB (1986) Two types of human mast cells that have distinct neutral protease compositions. Proc Natl Acad Sci U S A83: 4464-4468

Ivaska J, Pallari HM, Nevo J, Eriksson JE (2007) Novel functions of vimentin in cell adhesion, migration, and signaling. Exp Cell Res313: 2050-2062

Iwaki S, Tkaczyk C, Satterthwaite AB, Halcomb K, Beaven MA, Metcalfe DD, Gilfillan AM (2005) Btk plays a crucial role in the amplification of Fc epsilonRI-mediated mast cell activation by kit. J Biol Chem280: 40261-40270

Izushi K, Fujiwara Y, Tasaka K (1992) Identification of vimentin in rat peritoneal mast cells and its phosphorylation in association with histamine release. Immunopharmacology 23: 153-161

Jacobson K, Mouritsen OG, Anderson RG (2007) Lipid rafts: at a crossroad between cell biology and physics. Nat Cell Biol9: 7-14

Jamur M, Vugman I (1988) Rat peritoneal mast cell regranulation and acid phosphatase and trimetaphosphatase activity induced after stimulation by 48/80. A fluorescence, ultrastructural, and cytochemical study. Cell Mol Biol34: 231-237

Jamur MC, Grodzki AC, Berenstein EH, Hamawy MM, Siraganian RP, Oliver C (2005) Identification and characterization of undifferentiated mast cells in mouse bone marrow. Blood 105: 4282-4289 
Jamur MC, Grodzki AC, Moreno AN, Swaim WD, Siraganian RP, Oliver C (1997) Immunomagnetic isolation of rat bone marrow-derived and peritoneal mast cells. $J$ Histochem Cytochem45: 1715-1722

Jamur MC, Oliver C (2011) Origin, maturation and recruitment of mast cell precursors. Front Biosci (Schol Ed)3: 1390-1406

Jorpes E (1935) The chemistry of heparin. Biochem J29: 1817-1830

Jou I, Lee JH, Park SY, Yoon HJ, Joe EH, Park EJ (2006) Gangliosides trigger inflammatory responses via TLR4 in brain glia. Am J Pathol168: 1619-1630

Kalesnikoff J, Galli SJ (2008) New developments in mast cell biology. Nat Immunol9: $1215-1223$

Kim dK, Kim HS, Kim AR, Jang GH, Kim HW, Park YH, Kim B, Park YM, Beaven MA, Kim YM, Choi WS (2013) The scaffold protein prohibitin is required for antigenstimulated signaling in mast cells. Sci Signal6: ra80

Kimura T, Sakamoto H, Appella E, Siraganian RP (1997) The negative signaling molecule SH2 domain-containing inositol-polyphosphate 5-phosphatase (SHIP) binds to the tyrosine-phosphorylated beta subunit of the high affinity $\operatorname{IgE}$ receptor. J Biol Chem272: 13991-13996

Klein M, Klein-Hessling S, Palmetshofer A, Serfling E, Tertilt C, Bopp T, Heib V, Becker M, Taube C, Schild H, Schmitt E, Stassen M (2006) Specific and redundant roles for NFAT transcription factors in the expression of mast cell-derived cytokines. $J$ Immunol177: 6667-6674

Klemm S, Ruland J (2006) Inflammatory signal transduction from the Fc epsilon RI to NF-kappa B. Immunobiology211: 815-820

Koketsu R, Yamaguchi M, Suzukawa M, Tanaka Y, Tashimo H, Arai H, Nagase H, Matsumoto K, Saito H, Ra C, Yamamoto K, Ohta K (2013) Pretreatment with Low Levels of FceRI-Crosslinking Stimulation Enhances Basophil Mediator Release. Int Arch Allergy Immunol161 Suppl 2: 23-31 
Kosoff R, Chow HY, Radu M, Chernoff J (2013) Pak2 kinase restrains mast cell FceRI receptor signaling through modulation of Rho protein guanine nucleotide exchange factor (GEF) activity. J Biol Chem 288: 974-983

Kushnir-Sukhov NM, Brown JM, Wu Y, Kirshenbaum A, Metcalfe DD (2007) Human mast cells are capable of serotonin synthesis and release. J Allergy Clin Immunol119: 498-499

Lauterbach M, O'Donnell P, Asano K, Mayadas TN (2008) Role of TNF priming and adhesion molecules in neutrophil recruitment to intravascular immune complexes. $J$ Leukoc Biol83: 1423-1430

Lee JH, Kim JW, Kim dK, Kim HS, Park HJ, Park DK, Kim AR, Kim B, Beaven MA, Park KL, Kim YM, Choi WS (2011) The Src family kinase Fgr is critical for activation of mast cells and IgE-mediated anaphylaxis in mice. J Immunol187: 1807-1815

Li S, Esterberg R, Lachance V, Ren D, Radde-Gallwitz K, Chi F, Parent JL, Fritz A, Chen $\mathrm{P}$ (2011) Rack1 is required for Vangl2 membrane localization and planar cell polarity signaling while attenuating canonical Wnt activity. Proc Natl Acad Sci U S A108: 22642269

Lorenz U (2009) SHP-1 and SHP-2 in T cells: two phosphatases functioning at many levels. Immunol Rev228: 342-359

López-Bergami P, Habelhah H, Bhoumik A, Zhang W, Wang LH, Ronai Z (2005) RACK1 mediates activation of JNK by protein kinase C [corrected]. Mol Cell19: 309320

MacGlashan DW (2013) Basophil activation testing. J Allergy Clin Immunol132: 777787

Mahajan A, Barua D, Cutler P, Lidke DS, Espinoza FA, Pehlke C, Grattan R, Kawakami Y, Tung CS, Bradbury AR, Hlavacek WS, Wilson BS (2014) Optimal aggregation of FceRI with a structurally defined trivalent ligand overrides negative regulation driven by phosphatases. ACS Chem Biol9: 1508-1519 
Malbec O, Fong DC, Turner M, Tybulewicz VL, Cambier JC, Fridman WH, Daëron M (1998) Fc epsilon receptor I-associated lyn-dependent phosphorylation of Fc gamma receptor IIB during negative regulation of mast cell activation. J Immunol160: 1647-1658

Martini F, Riondino S, Pignatelli P, Gazzaniga PP, Ferroni P, Lenti L (2002) Involvement of GD3 in platelet activation. A novel association with Fcgamma receptor. Biochim Biophys Acta 1583: 297-304

Masserini M, Freire E (1986) Thermotropic characterization of phosphatidylcholine vesicles containing ganglioside GM1 with homogeneous ceramide chain length. Biochemistry25: 1043-1049

Mazucato VM, Silveira E Souza AM, Nicoletti LM, Jamur MC, Oliver C (2011) GD1bderived gangliosides modulate FceRI endocytosis in mast cells. J Histochem Cytochem59: 428-440

Metcalfe D, Baram D, Mekori Y (1997a) Mast cells. PHYSIOLOGICAL REVIEWS77: 1033-1079

Metcalfe DD, Baram D, Mekori YA (1997b) Mast cells. Physiol Rev77: 1033-1079

Metcalfe DD, Boyce JA (2006) Mast cell biology in evolution. J Allergy Clin Immunol117: 1227-1229

Metcalfe DD, Peavy RD, Gilfillan AM (2009) Mechanisms of mast cell signaling in anaphylaxis. J Allergy Clin Immunol124: 639-646; quiz 647-638

Metzger H, Alcaraz G, Hohman R, Kinet JP, Pribluda V, Quarto R (1986) The receptor with high affinity for immunoglobulin E. Annu Rev Immunol4: 419-470

Mielenz D, Vettermann C, Hampel M, Lang C, Avramidou A, Karas M, Jäck HM (2005) Lipid rafts associate with intracellular B cell receptors and exhibit a B cell stage-specific protein composition. J Immunol174: 3508-3517 
Milstein O, Tseng SY, Starr T, Llodra J, Nans A, Liu M, Wild MK, van der Merwe PA, Stokes DL, Reisner Y, Dustin ML (2008) Nanoscale increases in CD2-CD48-mediated intermembrane spacing decrease adhesion and reorganize the immunological synapse. $J$ Biol Chem283: 34414-34422

Minoguchi K, Swaim WD, Berenstein EH, Siraganian RP (1994) Src family tyrosine kinase p53/56lyn, a serine kinase and Fc epsilon RI associate with alpha-galactosyl derivatives of ganglioside GD1b in rat basophilic leukemia RBL-2H3 cells. J Biol Chem 269: 5249-5254

Mochly-Rosen D, Khaner H, Lopez J (1991) Identification of intracellular receptor proteins for activated protein kinase C. Proc Natl Acad Sci U S A88: 3997-4000

Mochly-Rosen D, Smith BL, Chen CH, Disatnik MH, Ron D (1995) Interaction of protein kinase $\mathrm{C}$ with RACK1, a receptor for activated C-kinase: a role in beta protein kinase $\mathrm{C}$ mediated signal transduction. Biochem Soc Trans23: 596-600

Monticelli S, Solymar DC, Rao A (2004) Role of NFAT proteins in IL13 gene transcription in mast cells. J Biol Chem279: 36210-36218

Morita Y, Siraganian RP (1981) Inhibition of IgE-mediated histamine release from rat basophilic leukemia cells and rat mast cells by inhibitors of transmethylation. $J$ Immunol127: 1339-1344

Nadler ST, Stoehr JP, Rabaglia ME, Schueler KL, Birnbaum MJ, Attie AD (2001) Normal Akt/PKB with reduced PI3K activation in insulin-resistant mice. Am J Physiol Endocrinol Metab281: E1249-1254

Nahm DH, Tkaczyk C, Fukuishi N, Colucci-Guyon E, Gilfillan AM, Metcalfe DD (2003) Identification of Fyn-binding proteins in MC/9 mast cells using mass spectrometry. Biochem Biophys Res Commun310: 202-208

Nishida K, Yamasaki S, Ito Y, Kabu K, Hattori K, Tezuka T, Nishizumi H, Kitamura D, Goitsuka R, Geha RS, Yamamoto T, Yagi T, Hirano T (2005) Fc\{epsilon\}RI-mediated mast cell degranulation requires calcium-independent microtubule-dependent translocation of granules to the plasma membrane. J Cell Biol170: 115-126 
Okamura H, Aramburu J, García-Rodríguez C, Viola JP, Raghavan A, Tahiliani M, Zhang X, Qin J, Hogan PG, Rao A (2000) Concerted dephosphorylation of the transcription factor NFAT1 induces a conformational switch that regulates transcriptional activity. Mol Cell6: 539-550

Oliver C, Fujimura A, Silveira E Souza AM, Orlandini de Castro R, Siraganian RP, Jamur MC (2007) Mast cell-specific gangliosides and FcepsilonRI follow the same endocytic pathway from lipid rafts in RBL-2H3 cells. J Histochem Cytochem55: 315-325

Oliver C, Sahara N, Kitani S, Robbins AR, Mertz LM, Siraganian RP (1992) Binding of monoclonal antibody AA4 to gangliosides on rat basophilic leukemia cells produces changes similar to those seen with Fc epsilon receptor activation. J Cell Biol116: 635646

Ono M, Bolland S, Tempst P, Ravetch JV (1996) Role of the inositol phosphatase SHIP in negative regulation of the immune system by the receptor Fc(gamma)RIIB. Nature383: 263-266

Ono Y, Hayashida T, Konagai A, Okazaki H, Miyao K, Kawachi S, Tanabe M, Shinoda M, Jinno H, Hasegawa H, Kitajima M, Kitagawa Y (2012) Direct inhibition of the transforming growth factor- $\beta$ pathway by protein-bound polysaccharide through inactivation of Smad2 signaling. Cancer Sci103: 317-324

Owen DM, Rentero C, Magenau A, Abu-Siniyeh A, Gaus K (2012) Quantitative imaging of membrane lipid order in cells and organisms. Nat Protoc7: 24-35

Owen DM, Williamson D, Rentero C, Gaus K (2009) Quantitative microscopy: protein dynamics and membrane organisation. Traffic 10: 962-971

Pallari HM, Eriksson JE (2006) Intermediate filaments as signaling platforms. Sci STKE2006: pe53

Patterson RL, van Rossum DB, Barrow RK, Snyder SH (2004) RACK1 binds to inositol 1,4,5-trisphosphate receptors and mediates Ca2+ release. Proc Natl Acad Sci U S A101: $2328-2332$ 
Pejler G, Rönnberg E, Waern I, Wernersson S (2010) Mast cell proteases: multifaceted regulators of inflammatory disease. Blood115: 4981-4990

Pfirsch-Maisonnas S, Aloulou M, Xu T, Claver J, Kanamaru Y, Tiwari M, Launay P, Monteiro RC, Blank U (2011) Inhibitory ITAM signaling traps activating receptors with the phosphatase SHP-1 to form polarized "inhibisome" clusters. Sci Signal4: ra24

Pierini L, Holowka D, Baird B (1996) Fc epsilon RI-mediated association of 6-micron beads with RBL-2H3 mast cells results in exclusion of signaling proteins from the forming phagosome and abrogation of normal downstream signaling. J Cell Biol134: $1427-1439$

Pike LJ (2009) The challenge of lipid rafts. J Lipid Res50 Suppl: S323-328

Pizzo P, Giurisato E, Bigsten A, Tassi M, Tavano R, Shaw A, Viola A (2004) Physiological T cell activation starts and propagates in lipid rafts. Immunol Lett91: 3-9

Pizzo P, Viola A (2004) Lipid rafts in lymphocyte activation. Microbes Infect6: 686-692

Poderycki M, Tomimori Y, Ando T, Xiao W, Maeda-Yamamoto M, Sauer K, Kawakami Y, Kawakami T (2010) A minor catalytic activity of Src family kinases is sufficient for maximal activation of mast cells via the high-affinity IgE receptor. $J$ Immunol184: 84-93

Pyenta PS, Holowka D, Baird B (2001) Cross-correlation analysis of inner-leafletanchored green fluorescent protein co-redistributed with $\operatorname{IgE}$ receptors and outer leaflet lipid raft components. Biophys J80: 2120-2132

Radin NS (1999) Chemotherapy by slowing glucosphingolipid synthesis. Biochem Pharmacol57: 589-595

Rao M, Mayor S (2005) Use of Forster's resonance energy transfer microscopy to study lipid rafts. Biochim Biophys Acta1746: 221-233

Ravetch JV, Bolland S (2001) IgG Fc receptors. Annu Rev Immunol19: 275-290 
Rivera J, Arudchandran R, Gonzalez-Espinosa C, Manetz TS, Xirasagar S (2001) A perspective: regulation of IgE receptor-mediated mast cell responses by a LAT-organized plasma membrane-localized signaling complex. Int Arch Allergy Immunol124: 137-141

Rivera J, Fierro NA, Olivera A, Suzuki R (2008) New insights on mast cell activation via the high affinity receptor for IgE. Adv Immunol98: 85-120

Roget K, Malissen M, Malbec O, Malissen B, Daëron M (2008) Non-T cell activation linker promotes mast cell survival by dampening the recruitment of SHIP1 by linker for activation of T cells. J Immunol180: 3689-3698

Ron D, Mochly-Rosen D (1994) Agonists and antagonists of protein kinase C function, derived from its binding proteins. J Biol Chem 269: 21395-21398

Runembert I, Queffeulou G, Federici P, Vrtovsnik F, Colucci-Guyon E, Babinet C, Briand P, Trugnan G, Friedlander G, Terzi F (2002) Vimentin affects localization and activity of sodium-glucose cotransporter SGLT1 in membrane rafts. J Cell Sci115: 713724

Seifert GJ, Lawson D, Wiche G (1992) Immunolocalization of the intermediate filamentassociated protein plectin at focal contacts and actin stress fibers. Eur J Cell Biol59: 138147

Sekino-Suzuki N, Yuyama K, Miki T, Kaneda M, Suzuki H, Yamamoto N, Yamamoto T, Oneyama C, Okada M, Kasahara K (2013) Involvement of gangliosides in the process of Cbp/PAG phosphorylation by Lyn in developing cerebellar growth cones. $J$ Neurochem124: 514-522

Settipane RA, Schwindt C (2013) Chapter 15: Allergic rhinitis. Am J Rhinol Allergy27 Suppl 1: 52-55

Sheets ED, Holowka D, Baird B (1999) Critical role for cholesterol in Lyn-mediated tyrosine phosphorylation of FcepsilonRI and their association with detergent-resistant membranes. J Cell Biol145: 877-887

Sibilano R, Frossi B, Pucillo CE (2014) Mast cell activation: a complex interplay of positive and negative signaling pathways. Eur J Immunol44: 2558-2566 
Silveira e Souza AM, Mazucato VM, de Castro RO, Matioli F, Ciancaglini P, de Paiva Paulino T, Jamur MC, Oliver C (2008) The alpha-galactosyl derivatives of ganglioside $\mathrm{GD}(1 \mathrm{~b})$ are essential for the organization of lipid rafts in RBL-2H3 mast cells. Exp Cell Res314: 2515-2528

Silveira E Souza AM, Mazucato VM, Jamur MC, Oliver C (2011) Lipid rafts in mast cell biology. J Lipids2011: 752906

Silveira e Souza AM, Trindade ES, Jamur MC, Oliver C (2010) Gangliosides are important for the preservation of the structure and organization of RBL-2H3 mast cells. J Histochem Cytochem58: 83-93

Simons K, Gerl MJ (2010) Revitalizing membrane rafts: new tools and insights. Nat Rev Mol Cell Biol11: 688-699

Simons K, Ikonen E (1997) Functional rafts in cell membranes. Nature387: 569-572

Singer SJ, Nicolson GL (1972) The fluid mosaic model of the structure of cell membranes. Science 175: 720-731

Siraganian RP (2003) Mast cell signal transduction from the high-affinity IgE receptor. Curr Opin Immunol15: 639-646

Siraganian RP, de Castro RO, Barbu EA, Zhang J (2010) Mast cell signaling: the role of protein tyrosine kinase Syk, its activation and screening methods for new pathway participants. FEBS Lett584: 4933-4940

Song J, Hagen G, Smith SM, Roess DA, Pecht I, Barisas BG (2002) Interactions of the mast cell function-associated antigen with the type I Fcepsilon receptor. Mol Immunol38: $1315-1321$

Sonnino S, Prinetti A, Nakayama H, Yangida M, Ogawa H, Iwabuchi K (2009) Role of very long fatty acid-containing glycosphingolipids in membrane organization and cell signaling: the model of lactosylceramide in neutrophils. Glycoconj J26: 615-621 
Stauffer TP, Meyer T (1997) Compartmentalized IgE receptor-mediated signal transduction in living cells. J Cell Biol139: 1447-1454

Stephan V, Seibt A, Dukanovic D, Skasa M, Swaim WD, Berenstein EH, Siraganian RP, Wahn V (1997) Anti-ganglioside monoclonal antibody AA4 selectively inhibits IgEinduced signal transduction pathways in rat basophilic leukemia cells. Mol Immunol34: $227-235$

Su TT, Guo B, Kawakami Y, Sommer K, Chae K, Humphries LA, Kato RM, Kang S, Patrone L, Wall R, Teitell M, Leitges M, Kawakami T, Rawlings DJ (2002) PKC-beta controls I kappa B kinase lipid raft recruitment and activation in response to BCR signaling. Nat Immunol3: 780-786

Surviladze Z, Dráberová L, Kubínová L, Dráber P (1998) Functional heterogeneity of Thy-1 membrane microdomains in rat basophilic leukemia cells. Eur J Immunol28: 18471858

Südhof TC, Rizo J (2011) Synaptic vesicle exocytosis. Cold Spring Harb Perspect Biol3

Swaim WD, Minoguchi K, Oliver C, Hamawy MM, Kihara H, Stephan V, Berenstein EH, Siraganian RP (1994) The anti-ganglioside monoclonal antibody AA4 induces protein tyrosine phosphorylations, but not degranulation, in rat basophilic leukemia cells. J Biol Chem269: 19466-19473

Tamir I, Stolpa JC, Helgason CD, Nakamura K, Bruhns P, Daeron M, Cambier JC (2000) The RasGAP-binding protein p62dok is a mediator of inhibitory FcgammaRIIB signals in B cells. Immunity12: 347-358

Tasaka K (1994) Molecular mechanism of histamine release: the role of intermediate filaments and membrane skeletons. J Physiol Pharmacol45: 479-492

Tzivion G, Luo ZJ, Avruch J (2000) Calyculin A-induced vimentin phosphorylation sequesters 14-3-3 and displaces other 14-3-3 partners in vivo. J Biol Chem275: 2977229778 
Udell CM, Samayawardhena LA, Kawakami Y, Kawakami T, Craig AW (2006) Fer and Fps/Fes participate in a Lyn-dependent pathway from FcepsilonRI to platelet-endothelial cell adhesion molecule 1 to limit mast cell activation. J Biol Chem281: 20949-20957

Underhill DM, Goodridge HS (2007) The many faces of ITAMs. Trends Immunol28: 6673

Usacheva A, Smith R, Minshall R, Baida G, Seng S, Croze E, Colamonici O (2001) The WD motif-containing protein receptor for activated protein kinase $\mathrm{C}$ (RACK1) is required for recruitment and activation of signal transducer and activator of transcription 1 through the type I interferon receptor. J Biol Chem276: 22948-22953

Vaidyanathan VV, Puri N, Roche PA (2001) The last exon of SNAP-23 regulates granule exocytosis from mast cells. J Biol Chem276: 25101-25106

Vig M, Kinet JP (2009) Calcium signaling in immune cells. Nat Immunol10: 21-27

Weis FM, Davis RJ (1990) Regulation of epidermal growth factor receptor signal transduction. Role of gangliosides. J Biol Chem 265: 12059-12066

Westerlund B, Slotte JP (2009) How the molecular features of glycosphingolipids affect domain formation in fluid membranes. Biochim Biophys Acta1788: 194-201

Wilson BS, Pfeiffer JR, Oliver JM (2000) Observing FcepsilonRI signaling from the inside of the mast cell membrane. J Cell Biol149: 1131-1142

Wollscheid B, von Haller PD, Yi E, Donohoe S, Vaughn K, Keller A, Nesvizhskii AI, Eng J, Li XJ, Goodlett DR, Aebersold R, Watts JD (2004) Lipid raft proteins and their identification in T lymphocytes. Subcell Biochem37: 121-152

Wong MX, Roberts D, Bartley PA, Jackson DE (2002) Absence of platelet endothelial cell adhesion molecule-1 (CD31) leads to increased severity of local and systemic IgEmediated anaphylaxis and modulation of mast cell activation. $J$ Immunol168: 6455-6462

Wu AL, Wang J, Zheleznyak A, Brown EJ (1999) Ubiquitin-related proteins regulate interaction of vimentin intermediate filaments with the plasma membrane. Mol Cell4: 619-625 
Yaka R, He DY, Phamluong K, Ron D (2003) Pituitary adenylate cyclase-activating polypeptide (PACAP(1-38)) enhances N-methyl-D-aspartate receptor function and brainderived neurotrophic factor expression via RACK1. J Biol Chem278: 9630-9638

Yaka R, Thornton C, Vagts AJ, Phamluong K, Bonci A, Ron D (2002) NMDA receptor function is regulated by the inhibitory scaffolding protein, RACK1. Proc Natl Acad Sci U S A99: 5710-5715

Yang J, Wang Q, Zheng W, Tuli J, Li Q, Wu Y, Hussein S, Dai XQ, Shafiei S, Li XG, Shen PY, Tu JC, Chen XZ (2012) Receptor for activated C kinase 1 (RACK1) inhibits function of transient receptor potential (TRP)-type channel Pkd2L1 through physical interaction. J Biol Chem287: 6551-6561

Yao F, Long LY, Deng YZ, Feng YY, Ying GY, Bao WD, Li G, Guan DX, Zhu YQ, Li JJ, Xie D (2014) RACK1 modulates NF- $\kappa$ B activation by interfering with the interaction between TRAF2 and the IKK complex. Cell Res24: 359-371

Yurugi H, Rajalingam K (2013) A role for prohibitin in mast cell activation: location matters. Sci Signal6: pe29

Zhang J, Billingsley ML, Kincaid RL, Siraganian RP (2000) Phosphorylation of Syk activation loop tyrosines is essential for Syk function. An in vivo study using a specific anti-Syk activation loop phosphotyrosine antibody. J Biol Chem275: 35442-35447

Zhang J, Kimura T, Siraganian RP (1998) Mutations in the activation loop tyrosines of protein tyrosine kinase Syk abrogate intracellular signaling but not kinase activity. $J$ Immunol161: 4366-4374

Zhang Y, Hagedorn CH, Wang L (2011) Role of nuclear receptor SHP in metabolism and cancer. Biochim Biophys Acta1812: 893-908

Zheng YZ, Berg KB, Foster LJ (2009) Mitochondria do not contain lipid rafts, and lipid rafts do not contain mitochondrial proteins. J Lipid Res50: 988-998 